DETERMINATION OF FLOOD HYDROGRAPHS FOR STREAMS IN SOUTH CAROLINA:

VOLUME 2. ESTIMATION OF PEAK-DISCHARGE FREQUENCY, RUNOFF

VOLUMES, AND FLOOD HYDROGRAPHS FOR URBAN WATERSHEDS

By Larry R. Bohman

U.S. GEOLOGICAL SURVEY

Water-Resources Investigations Report 92-4040

Prepared in cooperation with the

SOUTH CAROLINA DEPARTMENT OF HIGHWAYS

AND PUBLIC TRANSPORTATION

The contents of this report do not necessarily reflect the official views or policies of the South Carolina Department of Highways and Public Transportation or the Federal Highway Administration. This report does not constitute a standard, specification, or regulation.

Columbia, South Carolina 1992 
U.S. DEPARTMENT OF THE INTERIOR

MANUEL LUJAN, JR., Secretary

U.S. GEOLOGICAL SURVEY

Dallas L. Peck, Director

For additional information write to:

District Chief

U.S. Geological Survey

Stephenson Center-Suite 129

720 Gracern Road

Columbia, South Carolina 29210
Copies of this report may be purchased from:

U.S. Geological Survey Books and Open-File Reports Section Federal Center Box 25425

Denver, Colorado 80225 
Abstract $\ldots \ldots$

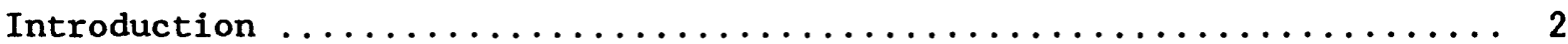

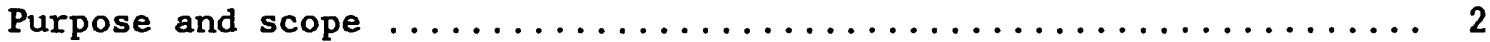

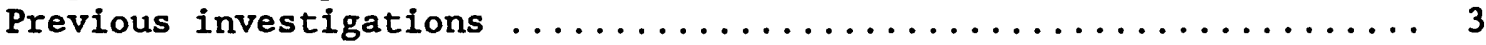

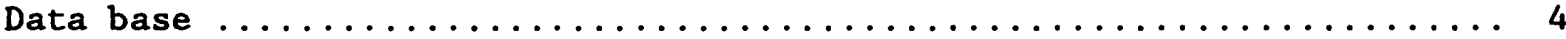

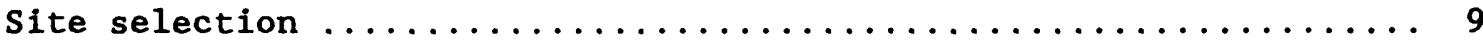

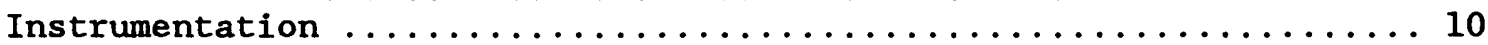

Processing and storage of short-term rainfall and

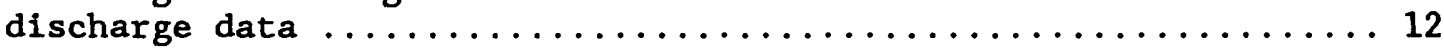

Long-term rainfall and evaporation ...................12

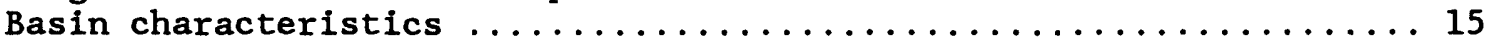

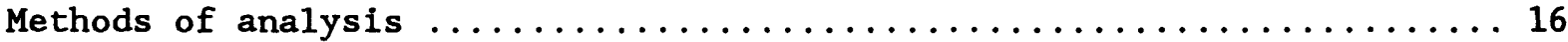

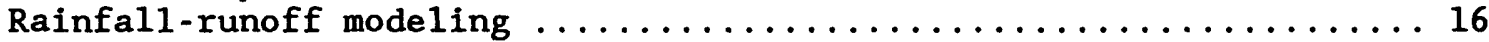

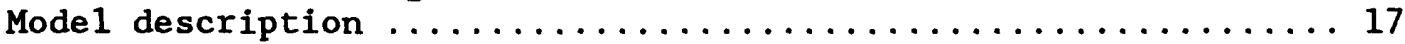

Model calibration ............................ 17

Long-term hydrograph synthesis ........................20

Determination of peak-discharge frequency .................20

Determination of $\mathrm{lag}$ time and runoff volume ...............23

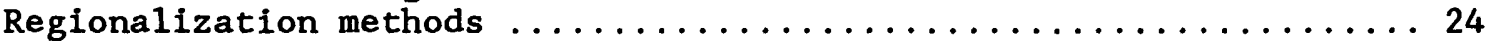

Dimensionless hydrograph analysis ....................27

Development of dimensionless hydrographs ............... 27

Adjusting average basin lag time for correct

runoff volume ............................ 35

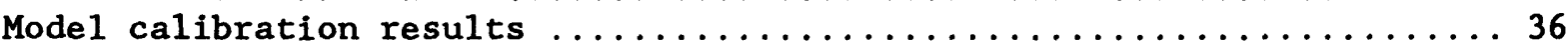

Peak-discharge-frequency relations at gaged urban basins ........... 36

Peak-discharge-frequency relations at ungaged urban basins ......... 41

Comparison to nationwide urban peak discharge equations ........41

Sensitivity analysis ...........................41

Tests for multicollinearity and bias ...................46

Application of peak-discharge-frequency equations ...........46

Limitations of method .........................46

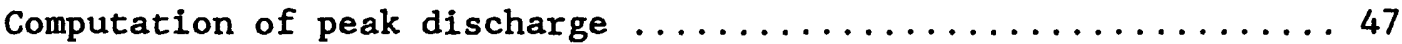

Example application .......................... 48

Average basin lag time relations for ungaged urban basins .........

Sensitivity analysis ............................49

Tests for multicollinearity and bias .................. 50

Application of average basin lag time equations .............50

Limitations of method .......................... 50

Computation of average basin lag time .................. 50

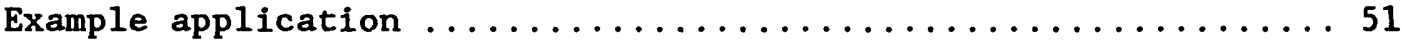

Runoff volume relations for ungaged urban basins ............... 51

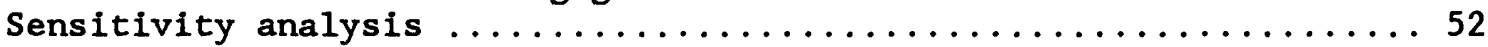

Tests for multicollinearity and bias $\ldots \ldots \ldots \ldots \ldots$

Application of runoff volume equations $\ldots \ldots \ldots \ldots \ldots$

Limitations of method ......................... 54

Computation of runoff volume ..................... 54

Example application ..........................55 
Estimation of flood hydrographs for ungaged urban basins ......... 55

Dimensionless hydrographs for South Carolina .............. 56

Adjusting average basin lag time for correct runoff volume ...... 57

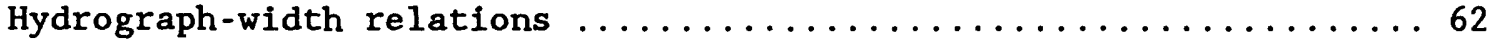

Sensitivity analysis $\ldots \ldots \ldots \ldots \ldots \ldots \ldots \ldots \ldots \ldots \ldots \ldots \ldots \ldots \ldots$

Application of the dimensionless hydrograph method ..........65

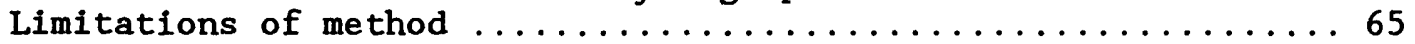

Computation of flood hydrographs ................. 66

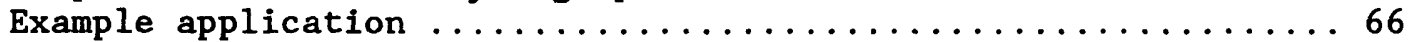

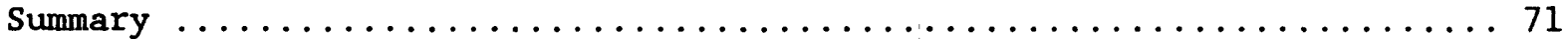

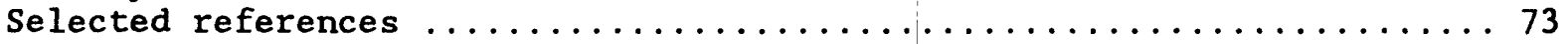

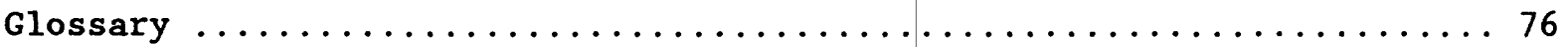

Supplement A. Rural flood-frequency equations for ungaged sites

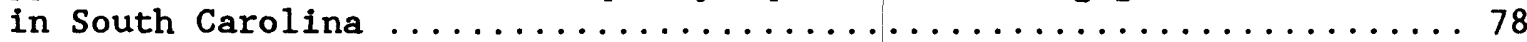

Supplement B. 2-year 2-hour rainfall amounts for South Carolina ...... 79

\section{ILLUSTRATIONS}

Figure 1. Map showing locations of cities, number of stream-gaging stations in each city, and physiographic provinces

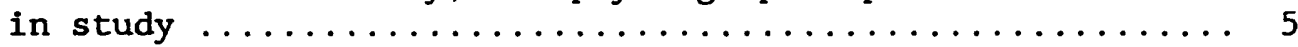

2. Photograph showing a typical rainfall-runoff data collection station ........................ 11

3. Map showing approximate locations of National Weather Service long-term rainfall and evaporation stations used in model calibrations ................... 13

4-19. Graphs showing:

4. Relation between observed runoff volumes and simulated runoff volumes from the rainfall-runoff model calibration of Rocky Branch at Columbia ......21

5. Relation between observed flood peak discharge and simulated flood-peak discharge from the rainfall-runoff model calibration of Rocky Branch at Columbia ..................... 22

6. Observed flood hydrograph and precipitation for Crane Creek Tributary at Columbia, August 18, 1986 
7. Unit hydrograph computed from observed data at

Crane Creek Tributary at Columbia, August 18, 1986, with a 1.00-inch precipitation-excess duration of 5 minutes and lag time of

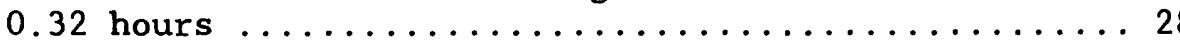

8. Average unit hydrograph with a precipitationexcess duration of 5 minutes for Crane Creek

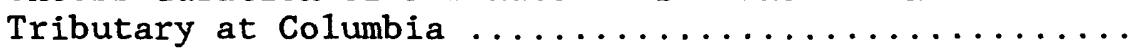

9. One-fourth-, one-third-, one-half-, and three-fourths-1ag time duration dimensionless hydrographs for Crane Creek Tributary at

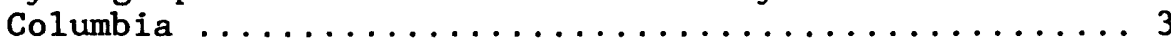

10. Average one-third-lag time dimensionless hydrograph for the lower Coastal Plain and the range of data from the eight stations from which it was

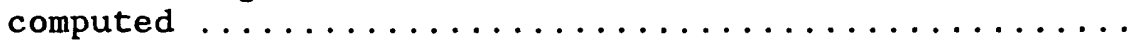

11. Estimated runoff hydrograph using observed peak flow and average basin lag time, and the observed runoff hydrograph showing width comparisons at 50 and 75 percent of peak discharge for Sunnyside Canal at Orangeburg, November $10,1987 \ldots \ldots \ldots \ldots . \ldots 34$

12. Sensitivity of computed peak discharge to changes in the three explanatory variables for selected peak-discharge-frequency equations ........... 45

13. Sensitivity of computed lag time to changes in the three explanatory variables for the average basin 1 ag time equation ................4

14. Sensitivity of computed runoff volume to changes in the three explanatory variables for the runoff volume equations ................. 52

15. Average dimensionless hydrographs for the Piedmont, upper Coastal Plain, and lower Coastal Plain with peaks aligned ............ 58

16. Dimensionless hydrograph for use in estimating hydrographs in the Piedmont and upper Coastal Plain physiographic provinces ...............6

17. Dimensionless hydrograph for use in estimating hydrographs in the lower Coastal Plain physiographic province .................61

18. Hydrograph-width relations for the indicated dimensionless hydrographs ...............66

19. Estimated hydrograph for the 100-year-peak discharge for Sunnyside Canal at Orangeburg .......70 
Table 1. Stream-gaging stations with unit-value data used in the urban study .......................... 6

2. National Weather Service evaporation stations used in calibration of the rainfall-runoff model and synthesis of hydrograph data ....................... 14

3. National Weather Service rainfall stations used in synthesis of long-term flood hydrograph data ......... 14

4. Rainfall-runoff model parameters ................. 18

5. Discharges at 5 -minute intervals with peaks aligned for five unit hydrographs with date of occurrence and average unit hydrograph computed for Crane Creek Tributary at Columbia ..................... 30

6. Optimized rainfall-runoff model parameters and standard error of estimate for peak discharge for each

7. Flood-frequency data from long-term synthesis for urban gaging stations in South Carolina and Georgia, and from observed data in North Carolina ............ 39

8. Selected basin characteristics for stations used in

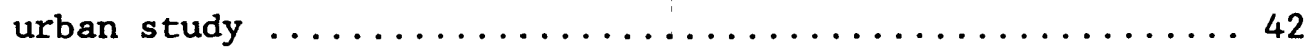

9. Equations for estimating peak discharges of urban

streams in South Carolina $\ldots \ldots \ldots \ldots \ldots \ldots \ldots \ldots \ldots$
10. Time and discharge ratios of the urban dimensionless hydrographs for the Piedmont-upper Coastal Plain and lower Coastal Plain regions ................ 59

11. Relation of discharge ratios to hydrograph width ratios for the Piedmont-upper Coastal Plain and lower Coastal Plain regions ................... 64

12. Example computation of hydrograph for 100-year peak discharge for Sunnyside Canal at Orangeburg ..........668 
CONVERSION FACTORS AND ABBREVIATIONS OF UNITS

\begin{tabular}{lll}
\multicolumn{1}{c}{ Multiply } & \multicolumn{1}{c}{ By } & \multicolumn{1}{c}{ To obtain } \\
inch (in.) & 2.54 & centimeter \\
foot (ft) & 0.3048 & meter \\
mile (mi) & 1.609 & kilometer \\
square mile $\left(\mathrm{mi}^{2}\right)$ & 2.590 & square kilometer \\
$\begin{array}{c}\text { cubic foot per second } \\
\left(\mathrm{ft}^{3} / \mathrm{s}\right)\end{array}$ & 0.028317 & cubic meter per second
\end{tabular}




\title{
DETERMINATION OF FLOOD HYDROGRAPHS FOR STREAMS IN SOUTH CAROLINA: VOLUME 2. ESTIMATION OF PEAK-DISCHARGE FREQUENCY, RUNOFF VOLUMES, AND FLOOD HYDROGRAPHS FOR URBAN WATERSHEDS
}

\author{
By Larry R. Bohman
}

\begin{abstract}
Knowledge of the magnitude and frequency of floods is needed for the design of highway drainage structures, for establishing flood insurance rates, and for many other uses by urban planners and engineers. Urban flood hydrographs also are needed for the design of many highway drainage structures and embankments and floodwater storage structures. This report describes methods that can be used to estimate peak-discharge-frequency relations, flood hydrographs, and flood volumes for ungaged urban streams in the Piedmont and Coastal Plain provinces of South Carolina. Data from stream-gaging stations on 34 urban watersheds in South Carolina, Georgia, and North Carolina, ranging in size from 0.18 to 41.0 square miles, were used in the analyses.
\end{abstract}

A rainfall-runoff model was calibrated for 23 urban drainage basins in South Carolina. The model, long-term rainfall data, and observed and synthetic evaporation data were used to synthesize a series of annual peak discharges for each site. The logarithms of the annual peaks were fitted to a Pearson Type III distribution to determine the frequency of peak discharge. Multiple regression equations were developed for estimating peak discharges having recurrence intervals of $2,5,10,25,50,100$, and 500 years using data from 34 gaging stations in South Carolina, North Carolina, and Georgia. The explanatory variables affecting peak discharge were drainage area, total impervious area, and rural discharge of equivalent recurrence interval. Average standard errors of prediction for the relations range from \pm 25.6 to \pm 34.3 percent.

A method is presented for estimating flood hydrographs by applying a specific peak discharge and adjusted basin lag time to one of two dimensionless hydrographs that were developed by using data from 30 stations in South Carolina and Georgia. The standard errors of estimate for the simulated hydrograph widths at 50 and 75 percent, respectively, of observed peak discharge were \pm 27.0 and \pm 29.8 percent for basins in the Piedmont and upper Coastal Plain and \pm 19.8 and \pm 24.5 percent for basins in the lower Coastal plain. An equation for estimating average basin lag time for use in applying the dimensionless hydrograph technique also was developed. Significant explanatory variables for estimating lag time were total impervious area; the 2-year, 2-hour rainfall amount; and a variable combining main channel length and slope (length/slope ${ }^{0.5}$ ). The standard error of prediction for the lag time relation was \pm 23.8 percent.

Two regression equations that provide average runoff volume, in inches, for a flood hydrograph with a specific peak discharge also are provided. The explanatory variables used in the volume equations were peak discharge, average basin lag time, and drainage area. The standard error of prediction for the volume equations was \pm 18.7 percent. 
The regression equations for estimating runoff volume are used to adjust average basin lag time before application of the dimensionless hydrograph method. This adjustment provides a more accurate estimate of the volume associated with the simulated hydrograph than would be obtained by using the dimensionless hydrograph method with the unadjusted average basin lag time.

\section{INIRODUCTION}

The design of highway drainage structures, establishment of flood-insurance rates, and other aspects of urban planning require knowledge of flood characteristics such as magnitude and frequency of flood-peak discharges and the shape of flood hydrographs. These flood characteristics for a watershed can be greatly affected as the basin becomes urbanized. Because the amount of impervious surface area increases with urbanization, infiltration and depression storage are reduced and the smooth, impervious surfaces allow rapid drainage. As a result, runoff volume usually increases and basin response time decreases. In addition, the drainage network is often modified by enlarging, straightening, and smoothing its channels and by installing storm sewers and curb-and-gutter systems. As a consequence of the more rapid runoff produced by these modifications, peak discharges also usually increase in comparison to rural basins.

In selecting designs for drainage structures, urban planners attempt to maximize flood protection and minimize costs. In cases where little or no embankment storage (increase in backwater resulting from road fill encroachment) is permissible, estimates of flood-peak discharge are sufficient for the design. In other cases, where some embankment storage may be allowed, risk analysis may be required to evaluate the flood hazard to lives, property, and stream stability (Corry and others, 1980). To fully assess these risks, a runoff hydrograph with a peak discharge of a specific recurrence interval may be needed to estimate the length of time that features such as roads and bridges will be inundated. In urban basins where little or no systematic streamflow data are available, it may be necessary to estimate the peak discharge for a specific recurrence interval or to construct a typical or design hydrograph by using one or more hydrograph estimation techniques. Although several techniques are available for this purpose, the data bases used to develop them have been national or statespecific. Due to a lack of urban flood data, no methods have been developed for use in South Carolina, and the applicability of techniques developed using data outside the State has not been tested. The need for this type of information led the U.S. Geological Survey (USGS), in cooperation with the South Carolina Department of Highways and Public Transportation, to develop methods for estimating peak-discharge frequency, runoff volumes, and flood hydrographs for ungaged urban watersheds in South Carolina.

\section{Purpose and Scope}

This report describes the results of a study to develop methods of estimating flood characteristics for ungaged urban watersheds in the Piedmont and Coastal Plain provinces of South Carolina. The report presents: (1) a summary of the methods of data collection and analysis used 
in this investigation, (2) rainfall-runoff modeling results, (3) peakdischarge-frequency estimates for the individual stations used in the regionalization process, (4) equations for estimating peak-dischargefrequency relations at ungaged sites, (5) equations for estimating average basin lag time, (6) methods for estimating the width and shape of a flood hydrograph associated with a peak discharge having a specific recurrence interval, and (7) equations for estimating average volume of a hydrograph having a specified peak discharge. Limitations and example applications are provided for using the methods presented in this report.

\section{Previous Investigations}

Putnam (1972) studied the effect of urban development on peak discharges in the Piedmont province of North Carolina using data from 42 sites in metropolitan areas of North Carolina. Sauer and others (1983) used data from 269 gaged basins in 56 cities in 31 states to develop floodfrequency relations for urban watersheds in the United States. These nationwide flood-frequency relations frequently have been used in South Carolina due to the lack of available urban streamflow data in the State. More recently, Inman (1988) developed regression equations using data from 45 urban drainage basins to estimate flood-frequency relations for ungaged urban streams in Georgia.

Most traditional approaches to hydrograph estimation rely on the unit-hydrograph method, whereby design hydrographs are computed by convolution of the unit hydrograph with rainfall excess. This method requires rainfall totals and actual or synthetic storm distributions, as well as the evaluation of a number of parameters that are needed to specify rainfall-runoff relations (determination of infiltration and other abstractions). In this methodology, the recurrence interval of the peak discharge and runoff are assumed to be the same as the rainfall recurrence interval for a specific storm. This assumption is not necessarily true and therefore may limit the utility of the unit hydrograph method for design purposes. Hydrographs also may be estimated using computer models, but a substantial amount of data and effort are required for proper model calibration.

In a nationwide study, Stricker and Sauer (1982) developed a dimensionless hydrograph that provides an easy-to-apply, direct method of estimating an urban-flood hydrograph. The dimensionless hydrograph method involves direct computation of a design hydrograph and requires only two parameters, the design peak discharge and basin lag time. In this method, a recurrence interval is assigned to the peak discharge and a typical or average hydrograph associated with the peak is computed. The resulting hydrograph or volume may or may not have the same recurrence interval. Inman (1986) developed and verified a dimensionless hydrograph for rural and urban basins in Georgia using data from 117 gaging stations (19 urban). Inman's hydrograph technique has been successfully applied on a nationwide scale as well as in several state studies. Bohman (1990) used the same techniques as those used by Inman and data from 49 rural gaging stations to develop dimensionless hydrographs for use in South Carolina, but their applicability to urban basins was not tested. 
DATA BASE

The equations and methods developed for this investigation are based on 5- to 15-minute-interval rainfall-runoff data collected at 30 gaging stations in South Carolina and Georgia for a period of 4 to 8 years and from 4 gaging stations in Charlotte, N.C., where 14 to 16 years of observed discharge data were available. The basins ranged in drainage area from 0.18 to 41.0 square miles and in impervious area from 10 to 51 percent.

Concurrent rainfall and discharge data were collected at 28 stations in 14 cities in South Carolina. One station was deleted prior to rainfallrunoff modeling because of deteriorating hydraulic conditions and drainagesystem modifications during the course of data collection. The data from the remaining 27 study sites were used to calibrate the rainfall-runoff model described later in this report. During calibration, problems not detected earlier became apparent at four additional stations. Some of these problems were unstable stage-discharge relations, unusual storage conditions within the basin (such as pervasive surface ponding due to chronically clogged street drains), and hydrographs with a significant interflow component (the model cannot accommodate basins in which the hydrograph recessions are protracted due to ground-water contribution).

Because of the problems mentioned above, data from 5 of the original 28 South Carolina data collection sites were deleted from the data base (including two stations that were the only gages in two cities), leaving 23 stations in the analysis. Data from seven gaging stations in Augusta and Savannah, Ga. were added to the data set. The final rainfall-runoff data base used in this study consisted of approximately 1,200 flood events observed at 30 gaging stations in 14 cities in South Carolina and Georgia (fig. 1, table 1). In addition, frequency data from 4 sites in Charlotte, N.C. were used in the regionalization of flood frequency.

Only simple (or noncompound) discharge hydrographs resulting from relatively uniform, short-duration rainfall events could be used for the hydrograph analyses (lag time, volume, and dimensionless hydrograph shape). A total of 139 flood events meeting these specifications were selected for use in the hydrograph analyses. 


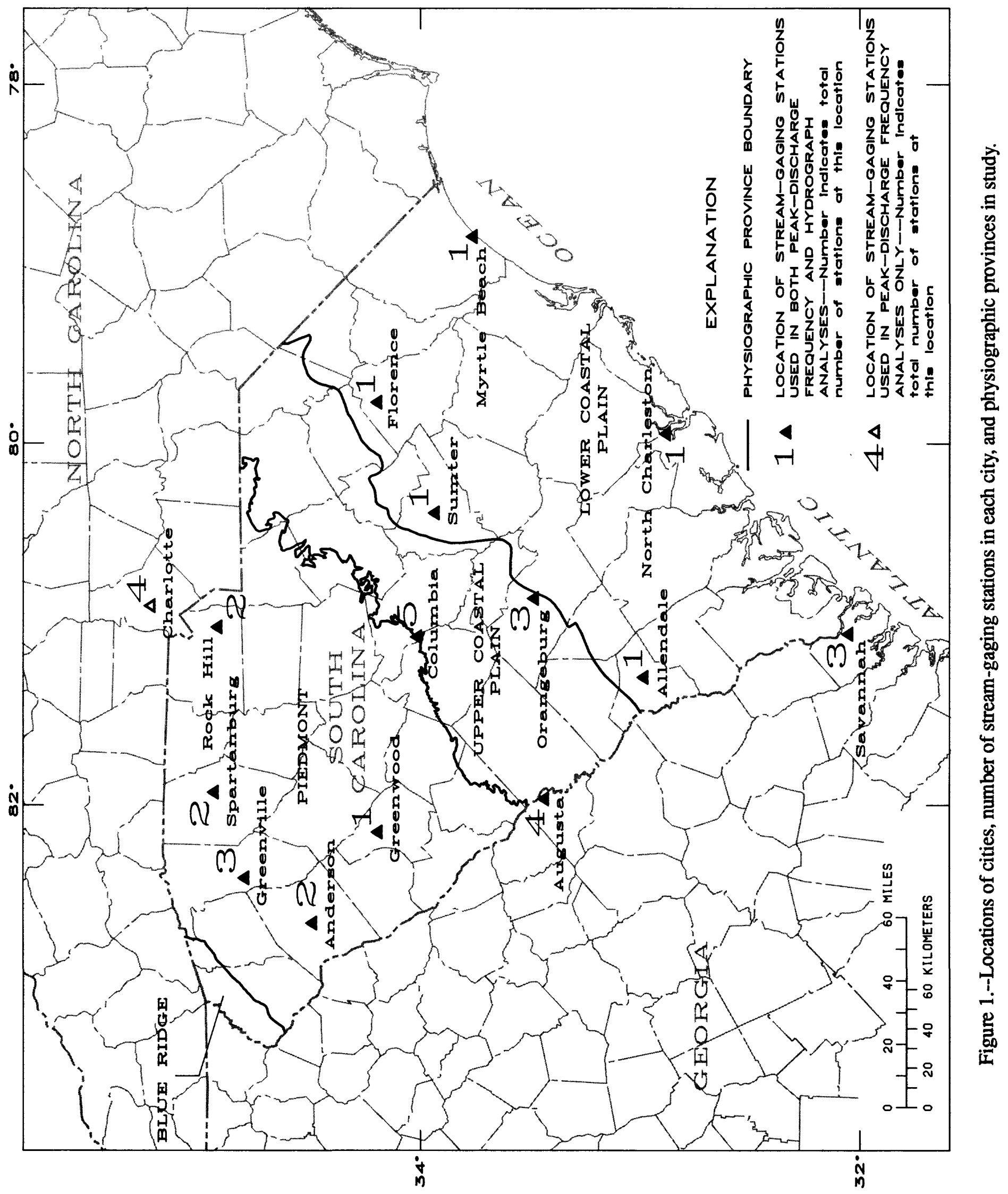


Table 1-- Stream-gaging stations with unit-value data used in the urban study [Lat, latitude; long, longitude]

\begin{tabular}{|c|c|c|c|}
\hline $\begin{array}{l}\text { Station } \\
\text { number }\end{array}$ & Station name & Location & $\begin{array}{l}\text { Period } \\
\text { of record }\end{array}$ \\
\hline \multicolumn{4}{|c|}{ Town of Allendale, S.C. } \\
\hline 02176380 & $\begin{array}{l}\text { Coosawhatchie River } \\
\text { tributary at } \\
\text { Allendale, S.C. }\end{array}$ & $\begin{array}{l}\text { Lat } 32^{\circ} 59^{\prime} 53^{\prime \prime} \text {, long } 81^{\circ} 19^{\prime} 01^{\prime \prime} \text {, } \\
\text { Allendale County, at culvert } \\
\text { on Secondary Road } 129\end{array}$ & $\begin{array}{l}11-13-85 \\
\text { to } \\
10-03-90\end{array}$ \\
\hline \multicolumn{4}{|c|}{ City of Anderson. S.C. } \\
\hline 02187260 & $\begin{array}{l}\text { Whitner Creek at } \\
\text { Anderson, S.C. }\end{array}$ & $\begin{array}{l}\text { Lat } 34^{\circ} 30^{\prime} 55^{\prime \prime}, \text { long } 82^{\circ} 39^{\prime} 35^{\prime \prime} \text {, } \\
\text { Anderson County, at culvert } \\
\text { on Lee Street }\end{array}$ & $\begin{array}{l}12-18-85 \\
\text { to } \\
10-20-89\end{array}$ \\
\hline 02187268 & $\begin{array}{l}\text { Dye Creek at } \\
\text { Anderson, S.C. }\end{array}$ & $\begin{array}{l}\text { Lat } 34^{\circ} 30^{\prime} 01^{\prime \prime} \text {, long } 82^{\circ} 40^{\prime} 13^{\prime \prime} \text {, } \\
\text { Anderson County, at culvert } \\
\text { on Market Street }\end{array}$ & $\begin{array}{l}01-30-86 \\
\text { to } \\
11-01-90\end{array}$ \\
\hline \multicolumn{4}{|c|}{ City of Augusta, Ga. } \\
\hline 02196570 & $\begin{array}{l}\text { Raes Creek } \\
\text { tributary No. } 2 \\
\text { at Augusta, Ga. }\end{array}$ & $\begin{array}{l}\text { Lat } 33^{\circ} 32^{\prime} 19^{\prime \prime} \text {, long } 82^{\circ} 02^{\prime} 34^{\prime \prime} \text {, } \\
\text { Richmond County, at culvert } \\
\text { on Skinner Mill Road at } \\
\text { junction with Boy Scout Road }\end{array}$ & $\begin{array}{l}02-22-79 \\
\text { to } \\
10-02-85\end{array}$ \\
\hline 02196605 & $\begin{array}{l}\text { Raes Creek } \\
\text { tributary No. } 1 \\
\text { at Augusta, Ga. }\end{array}$ & $\begin{array}{l}\text { Lat } 33^{\circ} 29^{\prime} 36^{\prime \prime} \text {, long } 82^{\circ} 02^{\prime} 17^{\prime \prime} \text {, } \\
\text { Richmond County at culvert on } \\
\text { Boy Scout Road }\end{array}$ & $\begin{array}{l}03-23-79 \\
\text { to } \\
10-05-85\end{array}$ \\
\hline 02196760 & $\begin{array}{l}\text { Rocky Creek } \\
\text { tributary at } \\
\text { Augusta, Ga. }\end{array}$ & $\begin{array}{l}\text { Lat } 33^{\circ} 27^{\prime} 07^{\prime \prime} \text {, long } 82^{\circ} 02^{\prime} 57^{\prime \prime} \text {, } \\
\text { Richmond County, at culvert } \\
\text { on U.S. Highways } 78 \text { and } 278\end{array}$ & $\begin{array}{l}02-22-79 \\
\text { to } \\
10-02-85\end{array}$ \\
\hline 02196850 & $\begin{array}{l}\text { Butler Creek } \\
\text { tributary at } \\
\text { Augusta, Ga. }\end{array}$ & $\begin{array}{l}\text { Lat } 33^{\circ} 25^{\prime} 00^{\prime \prime}, \text { long } 82^{\circ} 04^{\prime} 41^{\prime \prime} \text {, } \\
\text { Richmond County, at culvert } \\
\text { on Meadowbrook Drive }\end{array}$ & $\begin{array}{l}02-24-79 \\
\text { to } \\
02-16-82\end{array}$ \\
\hline \multicolumn{4}{|c|}{ City of Columbia, S.C. } \\
\hline 02162093 & $\begin{array}{l}\text { Smith Branch } \\
\text { at Columbia, S.C. }\end{array}$ & $\begin{array}{l}\text { Lat } 34^{\circ} 01^{\prime} 38^{\prime \prime}, \text { long } 81^{\circ} 02^{\prime} 31^{\prime \prime} \text {, } \\
\text { Richland County, at culvert } \\
\text { on North Main Street }\end{array}$ & $\begin{array}{l}07-12-76 \\
\text { to } \\
\text { present }\end{array}$ \\
\hline 02167020 & $\begin{array}{l}\text { Crane Creek } \\
\text { tributary at } \\
\text { Columbia, S.C. }\end{array}$ & $\begin{array}{l}\text { Lat } 34^{\circ} 03^{\prime} 02^{\prime \prime}, \text { long } 81^{\circ} 02^{\prime} 05^{\prime \prime} \text {, } \\
\text { Richland County, at culvert } \\
\text { on Carola Street }\end{array}$ & $\begin{array}{l}10-09-85 \\
\text { to } \\
10-11-89\end{array}$ \\
\hline
\end{tabular}


Table 1-- Stream-gaging stations with unit-value data used in the urban study--Continued

[Lat, latitude; 1ong, longitude]

\begin{tabular}{|c|c|c|c|}
\hline $\begin{array}{l}\text { Station } \\
\text { number }\end{array}$ & Station name & Location & $\begin{array}{l}\text { Period } \\
\text { of record }\end{array}$ \\
\hline 02168845 & $\begin{array}{l}\text { Saluda River } \\
\text { tributary at } \\
\text { Columbia, S.C. }\end{array}$ & $\begin{array}{l}\text { Lat } 34^{\circ} 02^{\prime} 26^{\prime \prime}, \text { long } 81^{\circ} 08^{\prime} 29^{\prime \prime} \text {, } \\
\text { Richland County, at culvert } \\
\text { on Bush River Road }\end{array}$ & $\begin{array}{l}10-18-85 \\
\text { to } \\
10-11-89\end{array}$ \\
\hline 02169505 & $\begin{array}{l}\text { Rocky Branch at } \\
\text { Columbia, S.C. }\end{array}$ & $\begin{array}{l}\text { Lat } 33^{\circ} 59^{\prime} 41^{\prime \prime}, \text { long } 81^{\circ} 01^{\prime} 26^{\prime \prime} \text {, } \\
\text { Richland County, at culvert } \\
\text { on Pickens Street }\end{array}$ & $\begin{array}{l}08-14-84 \\
\text { to } \\
12-06-90\end{array}$ \\
\hline 02169568 & $\begin{array}{l}\text { Pen Branch at } \\
\text { Columbia, S.C. }\end{array}$ & $\begin{array}{l}\text { Lat } 34^{\circ} 00^{\prime} 46^{\prime \prime}, \text { long } 80^{\circ} 58^{\prime} 56^{\prime \prime} \text {, } \\
\text { Richland County, at culvert } \\
\text { on Brentwood Street }\end{array}$ & $\begin{array}{l}10-15-85 \\
\text { to } \\
10-11-89\end{array}$ \\
\hline \multicolumn{4}{|c|}{ City of Florence, S.C. } \\
\hline 02131130 & $\begin{array}{l}\text { Gully Branch at } \\
\text { Florence, S.C. }\end{array}$ & $\begin{array}{l}\text { Lat } 34^{\circ} 11^{\prime} 00^{\prime \prime}, \text { long } 79^{\circ} 46^{\prime} 12^{\prime \prime} \text {, } \\
\text { Florence County, at culvert } \\
\text { on Cherokee Road }\end{array}$ & $\begin{array}{l}08-24-84 \\
\text { to } \\
10-04-89\end{array}$ \\
\hline \multicolumn{4}{|c|}{ City of Greenville, S.C. } \\
\hline 02160325 & $\begin{array}{l}\text { Brushy Creek } \\
\text { (Enoree River } \\
\text { tributary) at } \\
\text { Greenville, S.C. }\end{array}$ & $\begin{array}{l}\text { Lat } 34^{\circ} 53^{\prime} 00^{\prime \prime} \text {, long } 82^{\circ} 18^{\prime} 05^{\prime \prime} \text {, } \\
\text { Greenville County, at bridge } \\
\text { on Marchant Road }\end{array}$ & $\begin{array}{l}08-09-85 \\
\text { to } \\
11-13-90\end{array}$ \\
\hline 02163940 & $\begin{array}{l}\text { Richland Creek } \\
\text { tributary at } \\
\text { Greenville, S.C. }\end{array}$ & $\begin{array}{l}\text { Lat } 34^{\circ} 52^{\prime} 42^{\prime \prime} \text {, long } 82^{\circ} 23^{\prime} 52^{\prime \prime} \text {, } \\
\text { Greenville County, at culvert } \\
\text { on Southern Railroad }\end{array}$ & $\begin{array}{l}11-20-85 \\
\text { to } \\
10-18-89\end{array}$ \\
\hline 02164011 & $\begin{array}{l}\text { Brushy Creek } \\
\text { (Reedy River } \\
\text { tributary) at } \\
\text { Greenville, S.C. }\end{array}$ & $\begin{array}{l}\text { Lat } 34^{\circ} 49^{\prime} 25^{\prime \prime} \text {, long } 82^{\circ} 24^{\prime} 26^{\prime \prime} \text {, } \\
\text { Greenville County, at culvert } \\
\text { on Grove Road }\end{array}$ & $\begin{array}{l}08-18-83 \\
\text { to } \\
10-18-89\end{array}$ \\
\hline
\end{tabular}

City of Greenwood. S.C.

02166975 Sample Branch at Greenwood, S.C.
Lat $34^{\circ} 12^{\prime} 56^{\prime \prime}$, long $82^{\circ} 09^{\prime} 20^{\prime \prime}$, Greenwood County, at culvert on U.S. Highway 178 bypass
$11-19-85$

to

$10-12-90$

City of Myrtle Beach, S.C.

02110740 Midway Swash at Myrtle Beach, S.C.
Lat $33^{\circ} 39^{\prime} 44^{\prime \prime}$, long $78^{\circ} 55^{\prime} 25^{\prime \prime}$, Horry County, at culvert on U.S. Highway 17
$03-04-87$

to

$10-16-90$ 
Table 1--Stream-gaging stations with unit-value data used in the urban study--Continued

[Lat, latitude; long, longitude]

\begin{tabular}{|c|c|c|c|}
\hline $\begin{array}{l}\text { Station } \\
\text { number }\end{array}$ & Station name & Location & $\begin{array}{l}\text { Period } \\
\text { of record }\end{array}$ \\
\hline \multicolumn{4}{|c|}{ City of North Charleston. S.C. } \\
\hline 0217206930 & $\begin{array}{l}\text { Noisette Creek } \\
\text { at North } \\
\text { Charleston, S.C. }\end{array}$ & $\begin{array}{l}\text { Lat } 32^{\circ} 52^{\prime} 20^{\prime \prime} \text {, long } 79^{\circ} 59^{\prime} 28^{\prime \prime} \text {, } \\
\text { Charleston County, at culvert } \\
\text { on Southern Railroad below } \\
\text { Bexley Street }\end{array}$ & $\begin{array}{l}12-04-85 \\
\text { to } \\
10-23-89\end{array}$ \\
\hline \multicolumn{4}{|c|}{ City of Orangeburg. S.C. } \\
\hline 02173491 & $\begin{array}{l}\text { Hess Branch at } \\
\text { Orangeburg, S.C. }\end{array}$ & $\begin{array}{l}\text { Lat } 33^{\circ} 30^{\prime} 12^{\prime \prime} \text {, long } 80^{\circ} 52^{\prime} 41^{\prime \prime} \text {, } \\
\text { Orangeburg County, at culvert } \\
\text { on Middleton Road }\end{array}$ & $\begin{array}{l}05-08-86 \\
\text { to } \\
10-05-90\end{array}$ \\
\hline 02173495 & $\begin{array}{l}\text { Sunnyside Canal } \\
\text { at Orangeburg, S.C. }\end{array}$ & $\begin{array}{l}\text { Lat } 33^{\circ} 29 \cdot 31^{\prime \prime} \text {, long } 80^{\circ} 52^{\prime} 33^{\prime \prime} \text {, } \\
\text { Orangeburg County, at bridge } \\
\text { on Riverside Street }\end{array}$ & $\begin{array}{l}11-14-85 \\
\text { to } \\
10-19-90\end{array}$ \\
\hline 02174240 & $\begin{array}{l}\text { Middle Pen Branch } \\
\text { at Orangeburg, S.C. }\end{array}$ & $\begin{array}{l}\text { Lat } 33^{\circ} 29^{\prime} 14^{\prime \prime} \text {, long } 80^{\circ} 49^{\prime} 50^{\prime \prime} \text {, } \\
\text { Orangeburg County, at culvert } \\
\text { on U.S. Highway } 178 \text { bypass }\end{array}$ & $\begin{array}{l}11-25-85 \\
\text { to } \\
10-19-90\end{array}$ \\
\hline \multicolumn{4}{|c|}{ City of Savannah. Ga. } \\
\hline 02202542 & $\begin{array}{l}\text { Harmon Canal near } \\
\text { Savannah, Ga. }\end{array}$ & $\begin{array}{l}\text { Lat } 32^{\circ} 00^{\prime} 00^{\prime \prime} \text {, long } 81^{\circ} 07^{\prime} 45^{\prime \prime} \text {, } \\
\text { Chatham County, at culvert on } \\
\text { Perimeter Raad, within the } \\
\text { limits of Hunter Army Air- } \\
\text { field, } 50 \text { feet upstream from } \\
\text { Montgomery Cross Road }\end{array}$ & $\begin{array}{l}06-15-79 \\
\text { to } \\
03-15-86\end{array}$ \\
\hline 02203543 & $\begin{array}{l}\text { Wilshire Canal } \\
\text { near Savannah, Ga. }\end{array}$ & $\begin{array}{l}\text { Lat } 31^{\circ} 59^{\prime} 27^{\prime \prime}, \text { long } 81^{\circ} 08^{\prime} 15^{\prime \prime} \text {, } \\
\text { Chatham County, at culvert on } \\
\text { Tibet Avenue }\end{array}$ & $\begin{array}{l}04-25-79 \\
\text { to } \\
08-28-86\end{array}$ \\
\hline 02203544 & $\begin{array}{l}\text { Wilshire Canal } \\
\text { tributary near } \\
\text { Savannah, Ga. }\end{array}$ & $\begin{array}{l}\text { Lat } 31^{\circ} 58^{\prime} 25^{\prime \prime}, \text { long } 81^{\circ} 08^{\prime} 20^{\prime \prime} \text {, } \\
\text { Chatham County, at culvert on } \\
\text { Windsor Road }\end{array}$ & $\begin{array}{l}05-07-79 \\
\text { to } \\
08-12-86\end{array}$ \\
\hline \multicolumn{4}{|c|}{ City of Spartanburg, S.C. } \\
\hline 02156250 & $\begin{array}{l}\text { Chinquapin Creek } \\
\text { tributary at } \\
\text { Spartanburg, S.C. }\end{array}$ & $\begin{array}{l}\text { Lat } 34^{\circ} 57^{\prime} 34^{\prime \prime} \text {, long } 81^{\circ} 55^{\prime} 29^{\prime \prime} \text {, } \\
\text { Spartanburg County, at culvert } \\
\text { on Pine Street }\end{array}$ & $\begin{array}{l}12-17-85 \\
\text { to } \\
03-06-87\end{array}$ \\
\hline 02159785 & $\begin{array}{l}\text { Fairforest Creek } \\
\text { tributary at } \\
\text { Spartanburg, S.C. }\end{array}$ & $\begin{array}{l}\text { Lat } 34^{\circ} 57^{\prime} 10^{\prime \prime} \text {, long } 81^{\circ} 57^{\prime} 57^{\prime \prime} \text {, } \\
\text { Spartanburg County, at culvert } \\
\text { on Secondary Road } 485\end{array}$ & $\begin{array}{l}03-13-87 \\
\text { to } \\
11-02-90\end{array}$ \\
\hline
\end{tabular}


Table 1--Stream-gaging stations with unit-value data used in the urban study--Continued

[Lat, latitude; long, longitude]

\begin{tabular}{|c|c|c|c|}
\hline $\begin{array}{l}\text { Station } \\
\text { number }\end{array}$ & Station name & Location & $\begin{array}{c}\text { Period } \\
\text { of record }\end{array}$ \\
\hline \multicolumn{4}{|c|}{ City of Sumter, S.C. } \\
\hline 02135518 & $\begin{array}{l}\text { Turkey Creek at } \\
\text { Sumter, S.C. }\end{array}$ & $\begin{array}{l}\text { Lat } 33^{\circ} 55^{\prime} 13^{\prime \prime} \text {, long } 80^{\circ} 19^{\prime} 43^{\prime \prime} \text {, } \\
\text { Sumter County, at culvert on } \\
\text { East Liberty Street }\end{array}$ & $\begin{array}{l}11-08-85 \\
\text { to } \\
11-16-90\end{array}$ \\
\hline \multicolumn{4}{|c|}{ City of Rock Hill, S.C. } \\
\hline 02145940 & $\begin{array}{l}\text { Little Dutchman } \\
\text { Creek tributary } \\
\text { at Rock Hill, S.C. }\end{array}$ & $\begin{array}{l}\text { Lat } 34^{\circ} 58 \cdot 34^{\prime \prime}, \text { long } 81^{\circ} 01^{\prime} 02^{\prime \prime} \text {, } \\
\text { York County, at culvert on } \\
\text { Celanese Road }\end{array}$ & $\begin{array}{l}10-25-85 \\
\text { to } \\
09-22-89\end{array}$ \\
\hline 02146100 & $\begin{array}{l}\text { Manchester Creek } \\
\text { tributary at } \\
\text { Rock Hil1, S.C. }\end{array}$ & $\begin{array}{l}\text { Lat } 34^{\circ} 56^{\prime} 03^{\prime \prime}, \text { long } 81^{\circ} 00^{\prime} 11^{\prime \prime} \text {, } \\
\text { York County, at culvert on } \\
\text { Quantz Road }\end{array}$ & $\begin{array}{l}12-12-85 \\
\text { to } \\
10-03-89\end{array}$ \\
\hline
\end{tabular}

\section{Site Selection}

Extensive field reconnaissance was required to select the basins to be instrumented for this study. About 500 sites were located on maps and field inspected for possible use. Suitability for rain gage location, accessibility for discharge measurements, a bridge or culvert with hydraulic characteristics suitable for theoretical computation of peak discharge, absence of ponds or lakes, and land use in the drainage basin were some factors considered during the site inspections. Developing basins with large areas undergoing changes in impervious area or drainage efficiency were eliminated from the selection process. Basin characteristics such as drainage area, main channel slope, and degree of development were determined in the office to ensure a suitable distribution of basin characteristics. The final sites were equally distributed between the Piedmont and Coastal Plain physiographic provinces. 


\section{Instrumentation}

A recording stage gage was installed at each station. It was housed in a metal shelter mounted on top of a 12 -inch diameter vertical pipe stilling well that was located one structure-opening width upstream of the roadway as required for hydraulic computations. In cases where the stilling well was attached to the structure, an intake pipe was extended upstream to the desired location. A float and tape in the stilling well transmit stage by rotation of the input shaft on the recorder. Shaft rotation is converted by the instrument into a coded paper punch-tape record (in 0.01 -foot increments), which was collected every 3 weeks.

One rain gage was generally located near the stage gage for each basin. This rain gage was located so that precipitation amounts would not be influenced by surrounding buildings or vegetation. Rain-gage recorders were housed in shelters mounted on top of galvanized steel pipes that were 10-feet long, and 3-inches in diameter. Rain was collected by 8 -inch funnels and diverted to the stilling well where a float-type system, such as was used to record stream stage, transmitted rainfall information to a punch-tape. A photograph of a typical rainfall-runoff installation is shown in figure 2 .

Crest-stage indicators also were installed at each culvert site, with at least one in the upstream approach section and one at the downstream end of the culvert. A relation between the water-surface elevations from the upstream and downstream crest-stage indicators was established for each site. The fall through the culverts obtained from these headwater-tailwater relations and the culvert geometry were used to compute a theoretical stagedischarge relation as described by Bodhaine (1968).

The headwater-tailwater relation obtained from the crest-stage indicators also served other purposes. The relation should remain fairly consistent at a site. Deviations from the normal upstream-downstream relation could indicate an accumulation of debris at a culvert entrance that could produce excessive fall or a blockage downstream that would greatly reduce normal fall. Many times highway maintenance crews removed debris from culverts between gage-servicing trips. Plotting the upstream crestgage stage and the downstream crest-gage stage relation was the only evidence of blockage.

At some sites, the stage at the recording gage was different than the stage at the corresponding crest-stage indicator due to drawdown inside the stilling well resulting from improper intake design or due to the location of the recording gage in the drawdown zone near the culvert entrance. A relation between the upstream crest-stage and upstream recorder stage was established to enable plotting of the theoretical discharge computations, as described above, in reference to the recorder stage. The upstream creststage indicator and recorder stage relation also indicated problems with the stage hydrograph, such as a hanging float, a float tape that jumped the splines, or clogged intakes. 
Current meter measurements of discharge were made at all stations during regular site visits to better define the low ends of the stagedischarge relations. Measurements made at higher flows were used to confirm or correct the middle and high ends of the theoretical stage-discharge relations. Several stations were rated entirely by current meter measurements. Dye-dilution techniques were used to rate high flows at one gaging station.

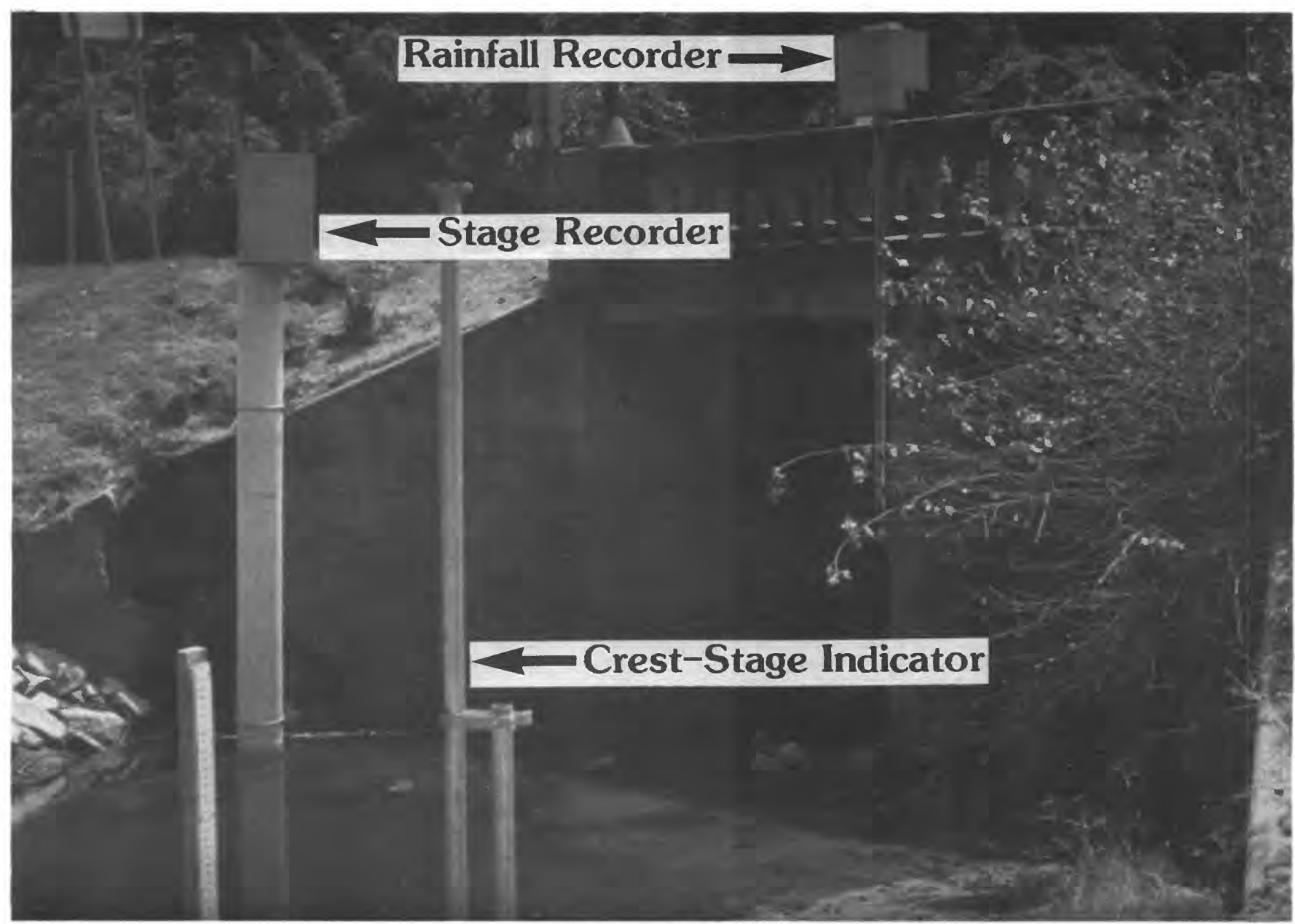

Figure 2.--Typical rainfall-runoff data collection station. 


\section{Processing and Storage of Short-Term Rainfall and Discharge Data}

Rainfall and discharge data for the entire perlod of record, except for periods of recorder malfunction, were loaded into the USGS computer data processing system. Generally, rainfall and discharge for the largest 10 to 15 storms per year were plotted against time, and total event rainfall amounts were compared with those from surrounding USGS or National Weather Service stations for uniformity. The hydrograph plots were used to visually edit the data for (1) timing problems, such as rising discharge long before recorded rainfall or abnormally long lag times, (2) clogged rain-gage intakes or hanging floats, (3) bad or misread punches, (4) estimation of the rising limb of a storm hydrograph if the float was out of the water at the beginning of a rise, and (6) estimation of the falling 1 imb in the event that the intakes or stilling well became partially clogged with sediment on the recession. After necessary editing and estimations were completed, the unit-value data ${ }^{1}$ for rainfall and discharge were reformatted for modeling and stored in the U.S. Geological Survey's WATSTORE computer data base (National WATer Data STOrage and REtrieval System) (Hutchinson, 1975).

The rainfall-runoff model requires continuous daily rainfall data to keep track of soil moisture during non-event periods. Therefore, daily rainfall totals were computed for all days. If periods of daily rainfall at a gage were missing because of a faulty recorder, data from a nearby USGS rain gage or a station operated by the National Weather Service were substituted.

The soil-moisture accounting routines of the rainfall-runoff model also require daily evaporation data. Daily pan evaporation data were available from seven National Weather Service stations in Charleston, Blackville, Florence, Sandhills Experiment Station (Columbia), Clark Hill, Simms Water Plant (Spartanburg), and Clemson (fig. 3, table 2).

\section{Long-Term Rainfall and Evaporation}

Long-term daily evaporation and rainfall and 5-minute event rainfall data are required for flood-peak simulation. Rainfall data were available for five National Weather Service stations in Columbia, Greenville, Charlotte, N.C.; Savannah, Ga.; and Augusta, Ga. (fig. 3, table 3). The data were compiled for previous studies by Whetstone (1982) and Inman (1983, 1988). In those studies about three to five storms per year were chosen as most likely to produce the annual peak discharge based on hydrologic judgment and were verified using a computer program that scans the daily records each year to find the storms in which the 1- or 2-day total rainfall exceeds a specified threshold magnitude. Data were obtained from graphic recorder charts at 5-minute intervals for those days.

1 "Unit-value data" refers to data with a shorter-than-one-day record interval, such as 5-minute, 15-minute, or 1-hour. 


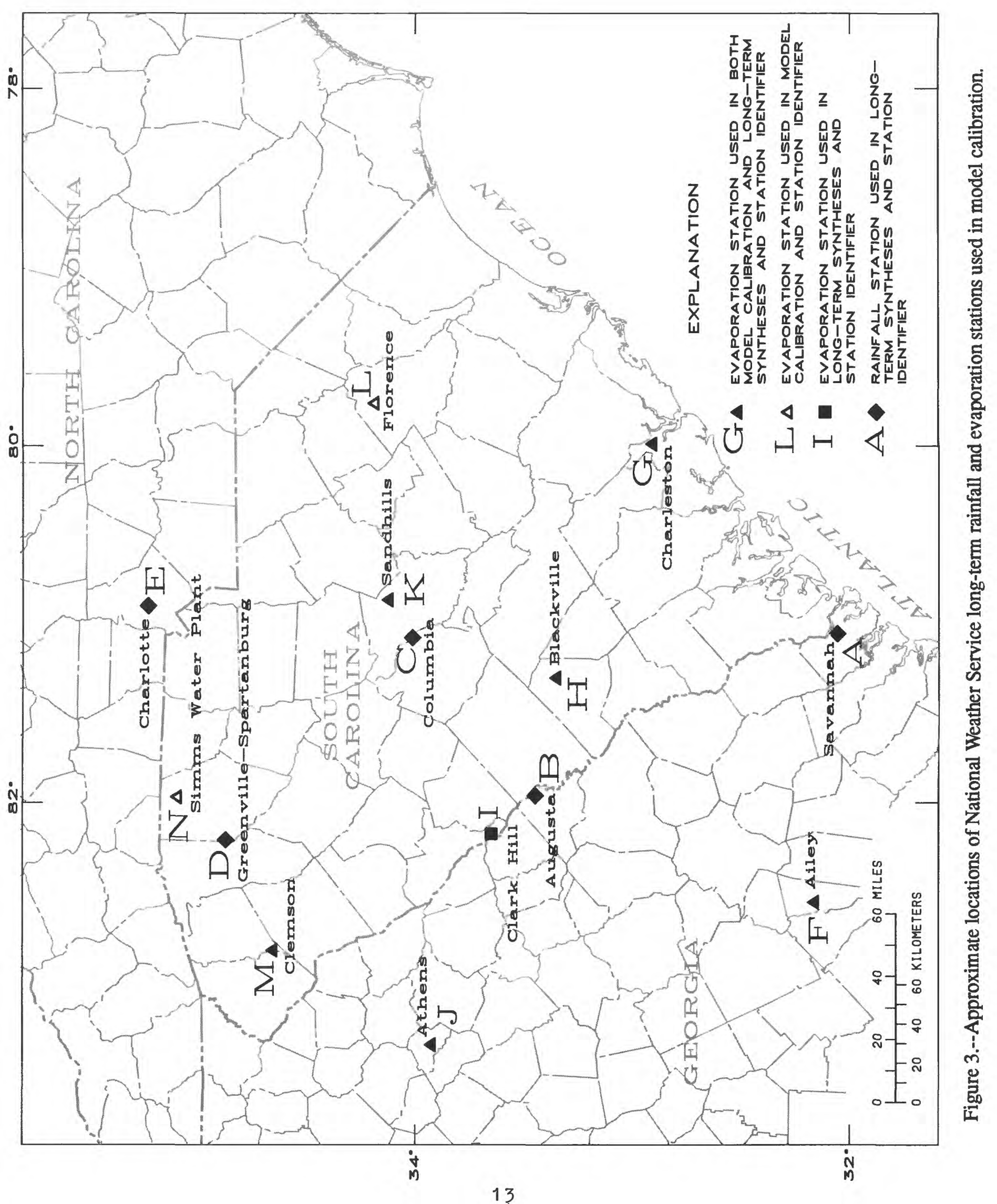


Table 2.- National Weather Service evaporation stations used in calibration of the rainfall-runoff model and synthes is of hydrograph data

$$
\text { [-., indicates no data] }
$$

\begin{tabular}{|c|c|c|c|c|c|}
\hline \multirow[b]{2}{*}{$\begin{array}{l}\text { Station } \\
\text { number }\end{array}$} & \multirow[b]{2}{*}{$\begin{array}{c}\text { Location and } \\
\text { identifier } \\
\text { (fig. } 3)\end{array}$} & \multicolumn{2}{|c|}{$\begin{array}{r}\text { Observed } \\
\text { record }\end{array}$} & \multicolumn{2}{|c|}{$\begin{array}{c}\text { Synthetic } \\
\text { record }\end{array}$} \\
\hline & & $\begin{array}{l}\text { Number } \\
\text { of } \\
\text { years }\end{array}$ & Period & $\begin{array}{l}\text { Number } \\
\text { of } \\
\text { years }\end{array}$ & Period \\
\hline 321100082340050 & $\begin{array}{l}\text { Ailey Evaporation } \\
\text { Station, Ga. (F) }\end{array}$ & 27 & $1947-73$ & 49 & $1898-46$ \\
\hline 325400080020001 & $\begin{array}{l}\text { Charleston Evaporation } \\
\text { Station, S.C. (G) }\end{array}$ & 17 & $\begin{array}{l}1965-74 \\
1984-90\end{array}$ & 76 & $\begin{array}{l}1898-64 \\
1975-83\end{array}$ \\
\hline 332200081190001 & $\begin{array}{l}\text { Blackville Evaporation } \\
\text { Station, S.C. (H) }\end{array}$ & 17 & $\begin{array}{l}1965-74 \\
1984-90\end{array}$ & 76 & $\begin{array}{l}1898-64 \\
1975-83\end{array}$ \\
\hline 334000082110001 & $\begin{array}{l}\text { Clark Hill Evaporation } \\
\text { Station, S.C. (I) }\end{array}$ & 15 & $\begin{array}{l}1965-74 \\
1985-90\end{array}$ & 67 & $1898-64$ \\
\hline 335500083210050 & $\begin{array}{l}\text { Athens Evaporation } \\
\text { Station, Ga. (J) }\end{array}$ & 42 & $1940-81$ & 38 & $1902-39$ \\
\hline 340800080520001 & $\begin{array}{l}\text { Sandhills Evaporation } \\
\text { Station, S.C. (K) }\end{array}$ & 17 & $\begin{array}{l}1965-74 \\
1984-90\end{array}$ & 67 & $1898-64$ \\
\hline 341800079440050 & $\begin{array}{l}\text { Florence 8NE, Evaporation } \\
\text { Station, S.C. (L) }\end{array}$ & 6 & $1985-90$ & 0 & $\cdots$ \\
\hline 344100082490001 & $\begin{array}{l}\text { Clemson Evaporation } \\
\text { Station, S.C. (M) }\end{array}$ & 17 & $\begin{array}{l}1965-74 \\
1984-90\end{array}$ & 67 & $1898-64$ \\
\hline 350700081580001 & $\begin{array}{l}\text { Simms Water Plant } \\
\text { Evaporation Station, } \\
\text { S.C. (N) }\end{array}$ & 5 & $1986-90$ & 0 & $\cdots$ \\
\hline
\end{tabular}

Table 3.- National Weather Service rainfall stations used in synthesis of long-term flood hydrograph data

\begin{tabular}{|c|c|c|c|}
\hline \multirow[b]{2}{*}{$\begin{array}{l}\text { Station } \\
\text { number }\end{array}$} & \multirow[b]{2}{*}{$\begin{array}{c}\text { Location and } \\
\text { identifier } \\
\text { (fig. 3) }\end{array}$} & \multicolumn{2}{|c|}{ Record } \\
\hline & & $\begin{array}{l}\text { Number } \\
\text { of } \\
\text { years }\end{array}$ & Period \\
\hline $\begin{array}{l}320800081120050 \\
332200081580050 \\
340000081030001 \\
345000082240001 \\
351400080560001\end{array}$ & $\begin{array}{l}\text { Savannah, Ga. (A) } \\
\text { Augusta, Ga. (B) } \\
\text { Columbia, S.C. (C) } \\
\text { Greenville-Spartanburg, S.C. } \\
\text { Charlotte, N.C. (E) }\end{array}$ & $\begin{array}{r}89 \\
72 \\
53 \\
\text { (D) } 49 \\
68\end{array}$ & $\begin{array}{l}1898-1987 \\
1902-73 \\
1901-53 \\
1918-71 \\
1901-69\end{array}$ \\
\hline
\end{tabular}


Daily pan evaporation data were not available for the entire period of rainfall record. The short periods of observed record for the National Weather Service stations in Clemson, Blackville, Charleston, Clark Hill, and Sandhills Experiment Station (Columbia) given in table 2 were used to synthesize harmonic average evaporation data for the period of record coinciding with the rainfall data.

\section{Basin Characteristics}

Several physical basin characteristics were required for the modeling phase of the investigation. Other physical or climatic parameters needed in the regionalization processes were selected in advance on the basis of previous similar studies in the Southeastern United States. The only basin characteristic measured but not used in any of the final estimating equations or procedures was the Basin Development Factor (BDF) suggested by Sauer and others (1983). The basin characteristics deemed as significant in this investigation were determined as follows:

A Drainage area (in square miles)--The drainage area contributing surface runoff to a specified location on a stream, measured in a horizontal plane and enclosed by a topographic divide. This was measured using a digitizer from USGS 7.5-minute topographic quadrangle maps or larger-scale maps of equivalent accuracy. Storm sewer maps obtained from city engineering or public works departments were used when available. Basin boundaries were field checked in areas of low relief when storm sewer information could not be obtained.

L Main-channel length (in miles)--Computed as the distance measured along the main channel from the gaged (or ungaged) site to the basin divide as determined from USGS 7.5-minute topographic quadrangle maps.

LT Average basin lag time (in hours)--The elapsed time from the centroid of rainfall excess to the centroid of the resultant runoff hydrograph. Equations for estimating average basin lag time are provided later in this report.

RI2 2-year 2-hour rainfall amount (in inches)--Determined by the Weather Bureau (1961) (now known as National Weather Service). For convenience of the user, a copy of the plate from this publication is presented in the supplemental data section of this report for determining RI2.

$\mathbf{R Q}_{\mathbf{T}}$ Rural discharge (in cubic feet per second)--Estimated using equations developed by Guimaraes and Bohman (1992) and presented in the supplemental data section of this report.

S Main-channel slope (in feet per mile)--Computed between points, which are 10 and 85 percent of the total main channel length upstream from the point of interest (gaged or ungaged site), from USGS 7.5-minute topographic quadrangle maps or larger-scale/smaller contour-interval maps of equivalent accuracy. 
TIA Total impervious area (in percent)--The percentage of the watershed that is impervious to infiltration of rainfall. This parameter was measured by the grid-overlay method using aerial photography.

According to Cochran (1963) a minimum of 200 points, or grid

intersections, per area or subbasin will provide a confidence level of 0.10. Grid intersections over points on buildings, streets, and parking lots were counted as impervious surface points. Those grid intersections occurring over forests, lawns, unpaved industrial yards, and so on, were treated as pervious surface points. The impervious points were divided by the total number of grid intersections to compute an estimate of the percentage of total impervious area. Three counts of at least 200 points per subbasin (usually many more) were obtained and the results averaged for the final value.

$\mathrm{UQ}_{\mathrm{T}}$ Urban peak discharge (in cubic feet per second)--Estimated using the equations presented in this report for use in the volume equations or the dimensionless hydrograph techniques.

\section{METHODS OF ANALYSIS}

The following sections explain the procedures and programs used in the rainfall-runoff modeling, peak-discharge-frequency analysis, lag time analysis, runoff volume analysis, and the dimensionless hydrograph analysis phases of this investigation.

The method of analysis for this investigation was to use the rainfall-runoff data collected at a variety of basins to calibrate a rainfall-runoff model. Long-term rainfall and evaporation data were then used to synthesize a series of annual peak discharges for each study basin. A frequency analysis was made using the annual peak discharges for each basin. These results were then regionalized using multiple regression techniques. Next, lag times, volumes, and dimensionless hydrographs were derived for selected storms using programs written by S.E. Ryan (USGS, written commun., 1986). Equations were again derived using multiple regression techniques for estimating lag times and volumes. Finally, volumes resulting from the dimensionless hydrograph technique were compared to the regression equation volumes. An adjustment factor to be applied to lag time was developed in order to achieve the best fit of observed hydrograph shapes and volumes.

\section{Rainfall-Runoff Modeling}

A minimum of 10 to 15 years of observed record is usually required to provide estimates of peak-discharge frequency at a gaging station. The use of calibrated rainfall-runoff models significantly shortens the data collection period required for flood-frequency analysis by synthesizing long-term runoff records from long-term rainfall records. The method is particularly appropriate for urban studies for which a shorter data collection period can minimize the effect of increased urbanization within the period. 
A modified version of the USGS Rainfall-Runoff Model, originally developed by Dawdy and others (1972), refined by Carrigan (1973), Boning (1974), and Carrigan and others (1977), was used for this study. J.M. Bergmann and others (USGS, written commun., 1990) modified the data management and automatic parameter optimization schemes of the previous versions and adapted the code for use on the USGS minicomputer system. This rainfall-runoff model (hereinafter referred to as RRM) was selected over other models because it is reliable, less costly, and not as time-consuming in terms of data required and model calibration.

RRM is a lumped-parameter model that has three basic components: antecedent soil-moisture accounting, infiltration, and surface-runoff routing. Ten parameters and a parameter to account for impervious area interact to simulate the hydrologic processes influencing runoff. The parameters and their definitions are listed in table 4.

Antecedent conditions affecting infiltration are determined by the soil moisture accounting component. Daily rainfall and evaporation are used with four parameters (EVC, RR, BMSM, and DRN) to simulate the redistribution of moisture in the soil column and evapotranspiration from the soil.

A modified form of the infiltration equation developed by Philip (1954) is used to compute the rainfall excess (rainfall minus infiltration) for each time interval. Three parameters (PSP, KSAT, and RGF), along with unit-value rainfall data and output reflecting antecedent conditions from the soil moisture-accounting component, determine the runoff volume for each event.

The surface-runoff routing component uses three parameters (KSW, TC, and $\mathrm{TP} / \mathrm{TC}$ ) and the Clark unit hydrograph method to transform the rainfall excess into the outflow hydrograph. The routing component was modified, as described by Carrigan (1973), to incorporate a triangularly shaped translation hydrograph as an internal feature of the computer program rather than an externally developed time-area histogram. This modification allowed separation of compound peaks, which provided more events for use in the calibration process.

\section{Mode1 Calibration}

Model calibration is the process of adjusting the parameter values in order to minimize differences between simulated and observed hydrographs. A broad range of peak discharges that meet the basic model assumption of nearly uniform rainfall over the basin is desirable for accurate model calibration. Obviously, the uniform rainfall assumption is never met by nature and an averaging effect is assumed to apply to the parameter fitting process. The effect of changes in the routing parameters (TC and KSW) remains constant for all discharges. However, changes in the runoff volume-producing parameters (KSAT and PSP, for example) will generally have a greater effect on larger floods, which influence the calibration bias. Therefore, a broad range of event sizes was used to calibrate the volume-producing model parameters, while the routing parameters were adjusted to give weight to the larger events, because the calibrated models were intended to synthesize relatively large events. 
Table 4.-- Rainfal1-runoff mode1 parameters

\begin{tabular}{|c|c|c|}
\hline Parameter & Units & Definition \\
\hline \multicolumn{3}{|c|}{ Antecedent soil-moisture accounting component } \\
\hline BMSM & inches & Soil moisture storage volume at field capacity. \\
\hline EVC & - & $\begin{array}{l}\text { Coefficient to convert pan evaporation to } \\
\text { potential evapotranspiration values. }\end{array}$ \\
\hline DRN & $\begin{array}{l}\text { inches per } \\
\text { hour }\end{array}$ & $\begin{array}{l}\text { A constant drainage rate for redistribution of } \\
\text { soil moisture. }\end{array}$ \\
\hline $\mathbf{R R}$ & -- & $\begin{array}{l}\text { Proportion of daily rainfall that infiltrates } \\
\text { the soil. }\end{array}$ \\
\hline \multicolumn{3}{|r|}{ Infiltration component } \\
\hline PSP & inches & $\begin{array}{l}\text { Represents the combined effects of soil moisture } \\
\text { content and suction at the wetting front for } \\
\text { soil moisture at field capacity. }\end{array}$ \\
\hline RGF & -- & $\begin{array}{l}\text { Ratio of PSP for soil moisture at wilting point } t \\
\text { that at field capacity. }\end{array}$ \\
\hline KSAT & $\begin{array}{l}\text { inches per } \\
\text { hour }\end{array}$ & $\begin{array}{l}\text { The minimum saturated value of hydraulic } \\
\text { conductivity used to determine soil infiltra- } \\
\text { tion rates. }\end{array}$ \\
\hline
\end{tabular}

Surface-runoff routing component

$\begin{array}{lll}\text { KSW hours } & \begin{array}{c}\text { Time characteristic of linear channel } \\ \text { storage reservoir. }\end{array} \\ \text { TC } & \begin{array}{c}\text { Duration of the triangular translation } \\ \text { hydrograph (time of concentration). }\end{array} \\ \text { TP/TC } & \text { Ratio of time-to-peak to time of concentration. } \\ \text { EIA } & \text { Urbanization component }\end{array}$


Approximately 30 to 45 floods per station were initially available at each study site for calibration. Once the event beginning times, ending times, and baseflow were specified, the initial parameter values for the model had to be estimated. The parameters DRN, EVC, and TP/TC were held constant throughout calibration of each study site. Calibration of the model proved to be very insensitive to large changes in DRN. Therefore, DRN was set to 1.00 as was done by Alley and Smith (1982). The value of EVC was fixed based on Class A pan evaporation values documented by Kohler and others (1959). TP/TC was fixed at 0.50 , as suggested by Mitchel1 (1972). The value of effective impervious area was initially estimated as threefourths of the total impervious area. Starting values for KSAT were obtained from Chow (1964) based on soil classification. Beginning values for other soil-moisture-accounting and infiltration parameters RR, BMSM, RGF, and PSP were obtained from Inman (1983, 1988) based on comparisons of physiographically similar basins. KSW and TC were estimated from plots of the larger non-compound peaks and unit-value rainfall.

A first simulation using the initial parameter estimates provided a scatter diagram of total observed rainfall and runoff volume (both in inches). Events, where rainfall greatly exceeded runoff, or where runoff was greater than rainfall were excluded from further use in the calibration. Other events were deleted only when justified by anomalies in the data or in the physiographic characteristics of the basin.

In general, the calibration process involved successive iterations of adjustments to the parameters controlling runoff volume followed by adjustments to the routing parameters. Manual optimization methods were used to define the initial values for input to the automatic optimization process of the model. Using automated parameter optimization with physically unrealistic initial parameter values can result in final parameter values that are even more unrealistic, despite a good fit between observed and predicted values. Therefore, several manual adjustments were made to those parameters affecting runoff volume and peak discharge before the automated scheme was employed.

Bias in modeled peak discharges and runoff volumes was evaluated by inspection of a graphic relation of computed and observed values. If the relation showed some deviation from a line having a 1:1 slope and passing through the origin, the calibration results were considered to be biased. It was found that varying the routing parameters such as TC and KSW only changed the intercept of the relation between observed and simulated peak discharges, whereas variation of the volume parameters such as PSP, KSAT, RGF, and EIA changed both the intercept and slope of the peak discharge and volume relations. Therefore, volume parameters were adjusted to change the intercept and slope of the observed-simulated relation, and routing parameters were subsequently used to further adjust the intercept of the peak-discharge relation.

When close agreement between average observed and simulated volumes was obtained and when the slope of the relation of computed and observed values was between about 0.9 and 1.1 ( 1.0 being the ideal value), the parameter values were considered reasonable for use in the automated parameter optimization phase of calibration. The computer-optimization technique is a 
trial-and-error, hill-climbing technique based on a method devised by Rosenbrock (1960) and revised by J.M. Bergmann and others (U.S. Geological Survey, written commun., 1990). RRM, like previous versions of the mode1, allows the user to optimize parameters based on reduction of total error, but it also can make adjustments necessary to achieve a regression slope close to 1.0 for either peaks or volumes. Routing parameter (KSW and TC) adjustments to obtain correct peak discharge were made manually after visually inspecting observed and simulated hydrograph plots. Final runs were made to fine-tune the routing parameters using the automated optimization routines.

Throughout the calibration process, the priority of fitting model parameters and judging the quality of the simulation results were:

1) An unbiased fit of the simulated versus observed values,

2) a reasonable group of parameter values that reflect observed conditions, and

3) minimized total error.

Final relations between simulated volumes and observed volumes and between simulated peak discharges and observed peak discharges for all floods at one site are shown in figures 4 and 5 , respectively.

\section{Long-Term Hydrograph Synthesis}

Discharge hydrographs were synthesized for each study site using a subroutine of RRM developed by Carrigan and others (1977). This part of the program uses the final parameter values from the calibrated rainfall-runoff model and long-term rainfall and evaporation records to produce a long-term series of synthetic hydrographs. Usually, data from the closest long-term rainfall and evaporation stations were used to synthesize the long-term hydrographs. Tests using different evaporation stations showed little sensitivity of volumes and peaks to the evaporation data sets. However, the model was sensitive to the long-term rainfall record chosen in each case to synthesize the series of annual-peak discharges for a basin. Even in cases where both long-term rainfall stations seemed to be located in physiographically and meteorologically similar settings, substantially different results were obtained when each rainfall-data set was applied to the calibrated basin models. For study basins located between rainfall stations where such a disparity in results occurred, the discharge-frequency estimates were interpolated by weighting the results inversely proportional to the distance between the site and the two rainfall stations.

\section{Determination of Peak-Discharge Frequency}

Once the 3 to 5 hydrographs were synthesized for each year of long-term record, the program selected the highest discharge for each water year. The logarithms of the annual peaks were then fitted to a Pearson Type III frequency distribution using guidelines from U.S. Water Resources Council Bulletin 17B (1981). These guidelines include methods for hand1ing low and high outliers. The skew coefficients computed directly from the synthesized data-frequency curves were not adjusted using the regional map skew provided in Bulletin 17B, because the regional skews were developed from rural data and do not represent urban conditions. 


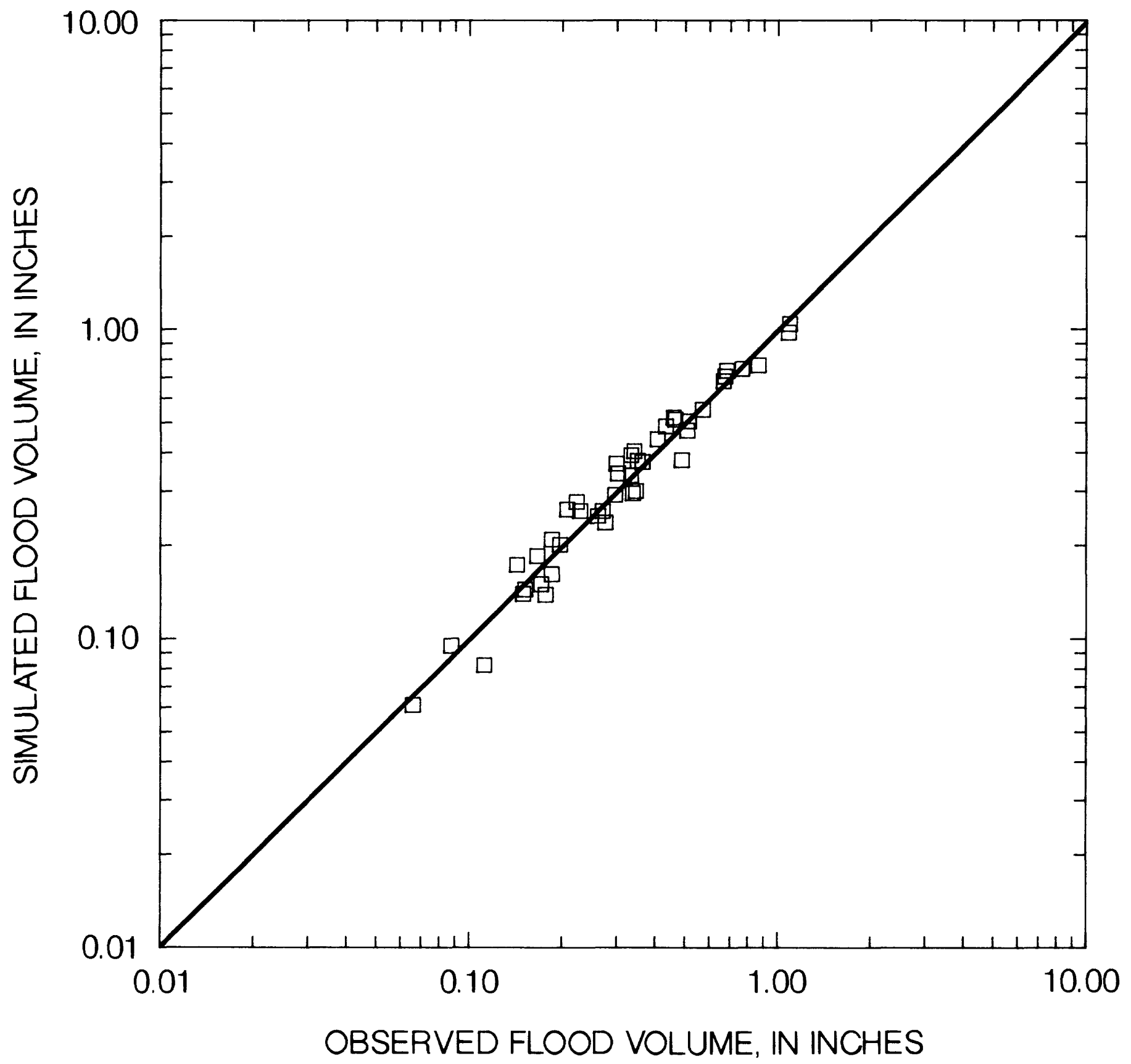

Figure 4.--Relation between observed runoff volumes and simulated runoff volumes from the rainfall-runoff model calibration of Rocky Branch at Columbia. 


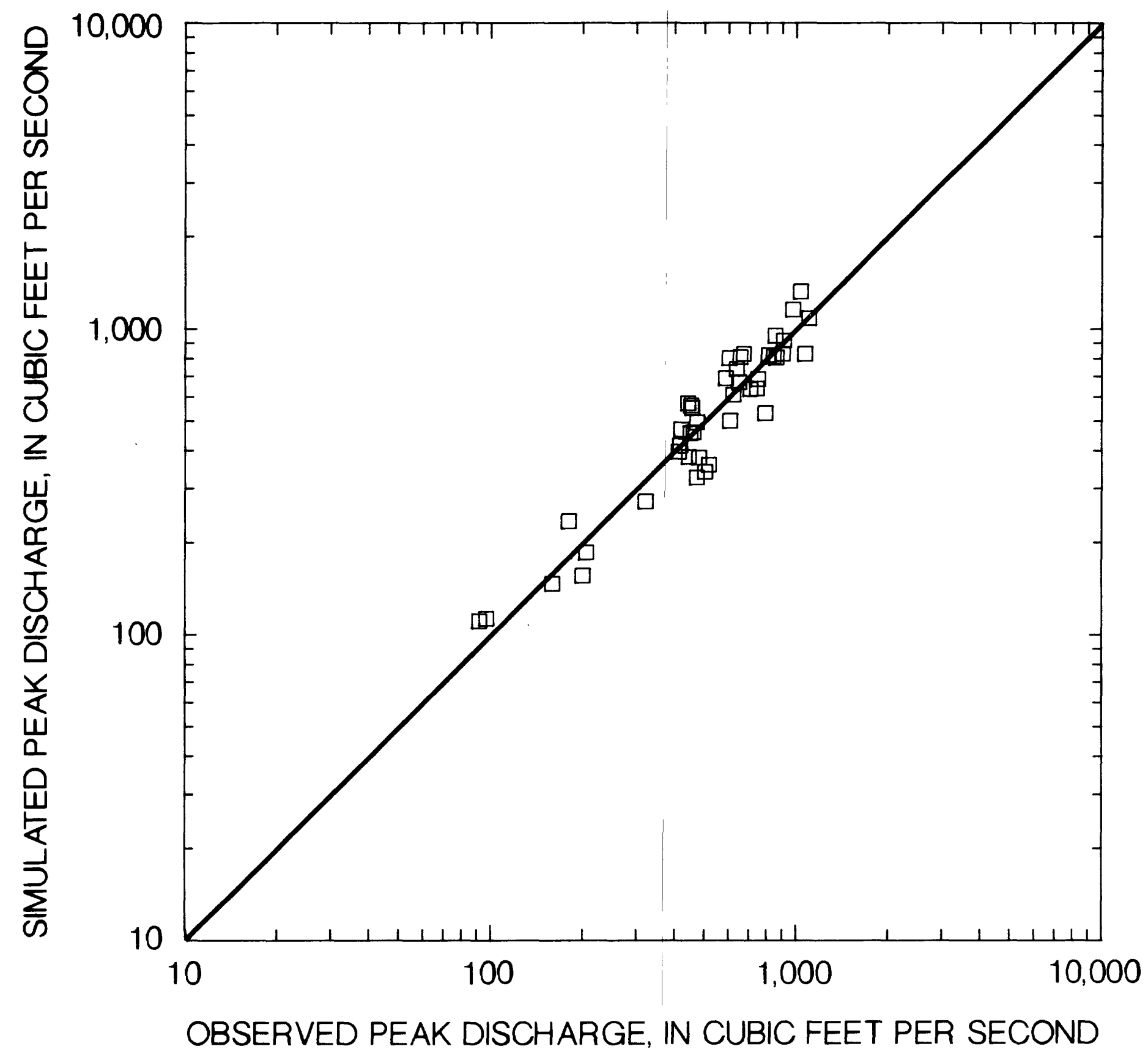

Figure 5.--Relation between observed flood-peak discharge and simulated flood-peak discharge from the rainfall-runoff model calibration of Rocky Branch at Columbia. 
Discharge-frequency curves for flood peaks simulated by RRM reflect existing detention storage that may be present at upstream roadway embankments with culverts of limited capacity, or minor flood-plain storage. Detention storage is difficult to quantify, because its effect varies with the magnitude of the flood. When increasing discharge causes flow over the road, the effect of storage on peak discharge is reduced. In basins with multiple crossings, this effect is complex and not subject to regionalization (Inman, 1983). The user would also find it difficult to compute this parameter at ungaged sites. Thus, the frequency and regression analyses reflect the average storage conditions that occurred during the events used in calibration.

It is possible for synthetic-frequency curves to be biased as a result of the smoothing effect (loss of variance) of the rainfall-runoff model. A reduction in standard deviation of annual flood peaks would result in a flattening of the flood-frequency curve; thus, flood estimates for long recurrence intervals (100 years, for example) may be considerably less than estimates based on observed data. Flood estimates for shorter recurrence intervals ( 2 years, for example) may be relatively unaffected. Several techniques have been developed by Lichty and Liscum (1978), Kirby (1975), and J.M. Sherwood (U.S. Geological Survey, written commun., 1991) to compensate for this loss of variance. No adjustments, however, were made to the frequency curves developed in this investigation for two reasons. First, variance can actually be increased instead of decreased, depending on how the model was calibrated. Second, insufficient data were available from previous studies at other small basins to compute reliable bias adjustment factors.

\section{Determination of Lag Time and Runoff Volume}

Average basin lag time, a necessary element in estimating flood hydrographs using the dimensionless hydrograph technique, was computed by averaging the unit hydrograph lag times for 3 to 5 representative observed events using programs developed by S.E. Ryan (U.S. Geological Survey, written commun., 1986). The programs are discussed in greater detail in the "Dimensionless Hydrograph Analysis" section of this report. Lag time is usually considered to remain constant for a basin and is defined as the time from the centroid of rainfall excess to the centroid of the runoff hydrograph (Stricker and Sauer, 1982). The lag-time values used in the South Carolina investigation were compared with the values obtained by using a method described by Kraijenhoff van de Leur (1966) in which lag time is computed as KSW $+1 / 2 \mathrm{TC}$, where $\mathrm{KSW}$ and TC (table 4) are those routing parameters computed in the final model calibrations for each site. No significant differences between the two methods were found.

Runoff volume in inches also was obtained as part of the unit hydrograph computations. Programs to compute runoff volume were developed by S.E. Ryan (U.S. Geological Survey, written commun., 1986). 


\section{Regionalization Methods}

Regionalization is the process by which records may be extended in space. In this process, the flow characteristics of gaged sites are related to measurable basin parameters so that estimates of those flow characteristics can be made at ungaged sites. Multiple regression is a technique that provides a mathematical equation of the relation between one response variable and two or more explanatory variables. The technique also provides a measure of the accuracy of the equation and a measure of the statistical significance of each explanatory variable in the equation. In the analysis, several equations (combinations of explanatory variables) are tested to determine which one provides the best estimate of the observed data set. To be included, an explanatory variable must be hydrologically valid and statistically significant.

Multiple regression analyses were made by use of the statistical Analysis System ${ }^{2}$ (SAS Institute, 1985). All variables were transformed to base 10 logarithms before analysis to insure a linear regression model and to achieve equal variance about the regression line throughout the range (Riggs, 1968). In most cases, a 95-percent confidence limit was used to evaluate the significance of the explanatory variables. Specific SAS analyses used in the selection of the equations were STEPWISE forward regression and MAXR. Stepwise forward regression begins with the most significant variable and adds variables until no more are significant. After each variable is added, the significance of every variable in the model is examined and variables already in the model may be removed. In MAXR, the best one-variable model, the best two-variable model, and so forth, are computed based on maximum improvement in the coefficient of determination.

The REG procedure in SAS was used to provide influence statistics and test for multicollinearity. An influential observation is a data point that exerts a large influence on the estimated regression coefficients. High leverage points were determined by values of Hat Diagonal, DFFITS, and Cooks D values on the SAS output (SAS Institute, 1985).

Multicollinearity in regression analysis occurs when the explanatory variables are not independent of one another. When this occurs, tests for significance in the regression may not be accurate or valid. For instance, if two explanatory variables are highly correlated, the regression analysis will divide their effect on the response variable, thus reducing the significance of each. The danger of this effect is that one or both of the variables may seem, erroneously, to be statistically insignificant (Sauer and others, 1983). The Variance Inflation Factor (VIF) in the REG procedure of SAS was used to determine multicollinearity.

${ }^{2}$ Use of trade names in this report is for identification purposes only and does not constitute an endorsement by the U.S. Geological Survey. 
The validity of a regression equation is generally established using: (1) the coefficient of determination, (2) the standard error of regression, (3) verification, (4) analysis of bias, and (5) analysis of sensitivity. The coefficient of determination $\left(R^{2}\right)$ and the standard error of regression (SER) can be used to express the accuracy of linear multiple regression. The $R^{2}$ statistic indicates the proportion of the total variation of the response variable that is explained by the explanatory variables. For example, an $R^{2}$ of 0.93 would indicate that the explanatory variables account for 93 percent of the variation in the response variable.

SER is, by definition, the standard deviation of the residuals of the regression equation and contains about two-thirds of the data within this range at the 95-percent confidence level. Conversely, about one-third of the data will fall outside of the standard error of regression.

Verification of the regression equations for this study was done by computing the standard error of prediction (SEP) using the PRESS (Prediction Sum of Squares) statistic from SAS. The PRESS statistic, according to Myers (1986), is determined by setting the first observation of the data set aside, and using the remaining n-1 observations to estimate the coefficients for the regression model. The first observation is then replaced, the second observation is withheld, and the coefficients are again estimated. Each observation is removed one at a time, and the model is fit $n$ times (sample size). The deleted observation is estimated each time, resulting in $n$ prediction errors (PRESS residuals). The final PRESS statistic is computed as the sum of the squares of these residuals. Because the prediction errors are independent of the equation used to estimate them, a true test of validation has been accomplished. In contrast to the SER, which measures how well a model performs at the sites used to develop it, the SEP is a measure of how accurately the regression equations will estimate the response variable at other than calibration sites (Sauer and others, 1983).

The standard error of prediction can be computed, as described by E.J. Gilroy (U.S. Geological Survey, written commun., 1988) for the PRESS statistic with the equation

$$
\operatorname{SEP}=\left((\operatorname{PRESS}(y))^{0.5}\right.
$$

where SEP is the standard error of prediction; PRESS is the prediction sum of squares; and $y=(1 / n)((n+p+1) /(n+p))((n-1) / n) ;$

where $\mathrm{n}$ is the sample size; and

$p$ is the number of parameters including the constant

Two tests for bias were performed, one for parameter bias and the other for geographical bias. A plot of the residuals (differences between observed and predicted values) and each of the explanatory variables for all observations was made in order to detect parameter bias. Obvious trends noted in such a plot would indicate that the regression equations might over- or under-estimate the value of the response variable at the extreme ranges of that explanatory variable. 
Geographical bias was examined by plotting residuals (or the average residual for a number of observations at one station) in percent on a state map. If no areal trends were apparent, the equation was assumed to be free of any geographical bias. A qualitative variable may also be included in the regression model to distinguish differences between physiographic/hydrologic regions. The linear form of a model with a qualitative variable usually takes the form:

$\log Z=\log A+a E+b \log B+c E \log B+d \log C+e E \log C \ldots$

where $\mathrm{Z}$ is the response variable;

$A$ is the regression constant;

$B, C$ are the explanatory variables;

$a, b, c, d, e$ are the regression coefficients; and

$E$ is a qualitative variable.

The qualitative variable is set to a value of one if the observation is in a specific region " $X$ " or to a value of zero if the observation is not in region "X". If the aE term is determined to be statistically significant by the regression analysis, then the intercept of the regression equation will differ substantially between region " $X$ " and the other region(s). If other explanatory variables that include the qualitative variable $E$ are significant, then the slope of the regression lines for those variables (explanatory variable coefficients) will differ significantly between regions. Thus, qualitative variables were used to detect significant differences between regions and to utilize data from both regions where data were sparse. For example, when all observations are used, the residuals for one region with only a few observations may be much larger than those of another region with numerous observations. A separate equation for the region with few observations could be developed, but the small number of observations would render the relation suspect. The inclusion of the qualitative variable utilizes the entire data set to establish the relation.

Errors in measurement or judgment may occur when determining values for the explanatory variables. Consequently, sensitivity analyses were performed for each regression equation developed in this study to illustrate the effects of errors in the explanatory variables on the computation of the response variable. For each equation, the means of the explanatory variables were calculated. The mean values were then substituted into the regression equations. Each explanatory variable was then varied by 5 -percent increments from -50 to +50 percent of its mean, while the values of the other variables were held constant. The percentage of change in the predicted (response) variable was then plotted against the percentage of change in the explanatory variable. 
A comparison was also made of the equations developed for urban flood magnitude and frequency in South Carolina to those developed in a nationwide study (Sauer and others, 1983). The nationwide study used data from 269 gaged basins in 56 cities and 31 states.

\section{Dimensionless Hydrograph Analysis}

A dimensionless hydrograph may be defined as a representative hydrograph shape for which the discharge is expressed as the ratio of discharge to peak discharge and the time as the ratio of time to lag time. It is developed by averaging typical hydrographs from a variety of watersheds. Estimates of the two principal hydrograph characteristics, peak discharge and basin lag time, are required for hydrograph estimation. Equations for estimating these characteristics are presented in this report. In a previous report of rural flood hydrographs (Bohman, 1990), an adjustment to basin lag time was needed to achieve the best fit of observed hydrograph volumes and widths in South Carolina. The adjusted lag times should be applied whenever a dimensionless hydrograph is used to estimate a design flood hydrograph.

\section{Development of Dimensionless Hydrographs}

The dimensionless hydrographs were based on data from 139 observed floods at 30 gaging stations in 14 cities in South Carolina and Georgia. A series of computer programs (S.E. Ryan, U.S. Geological Survey, written commun., 1986) was used as an aid in developing the dimensionless hydrograph shapes (steps 3 through 7 , below) and to perform subsequent statistical analyses. The steps in the dimensionless hydrograph development process, based in part on information by Inman (1986), are described below.

(1) A discharge hydrograph is plotted on semilogarithmic paper for 3 to 5 floods at each of the 30 gaging stations. The end of direct runoff is estimated to occur when a straight-line recession begins. A unit hydrograph with a rainfall-excess duration (hereafter referred to as duration) equal to one recording interval is then computed using the unit hydrograph method described by $0^{\prime}$ Donnell (1960). This method assumes that the first and last discharges supplied by the user represent base flow. Intervening base-flow discharges are computed by interpolation. These amounts are then subtracted from the discharge ordinates to obtain the direct runoff hydrograph from which the unit hydrograph is derived. The lag time of each unit hydrograph also is computed. A hydrograph for a typical event is illustrated in figure 6 , and the corresponding unit hydrograph is shown in figure 7.

(2) The unit hydrographs with inconsistent shapes are eliminated and unit hydrographs from additional storms are computed if needed. 


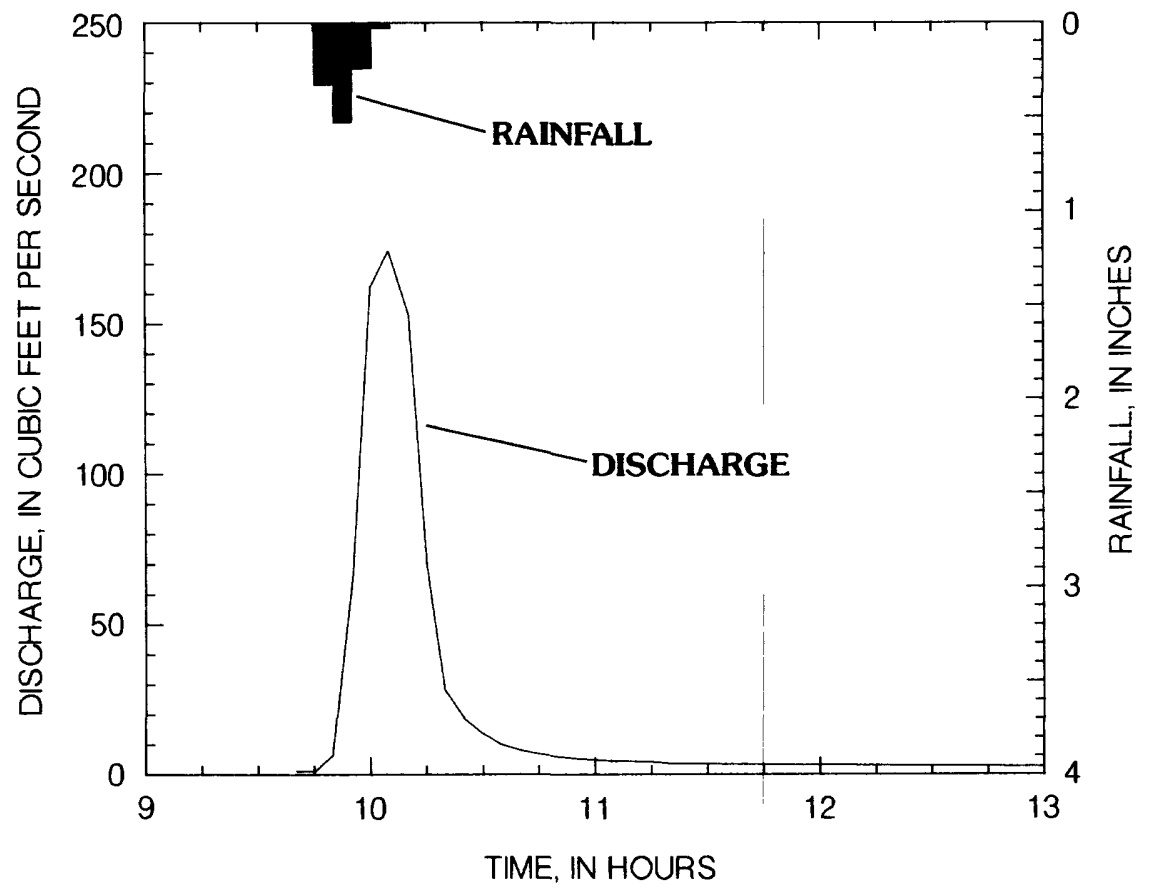

Figure 6.--Observed flood hydrograph and precipitation for Crane Creek Tributary at Columbia, August 18, 1986

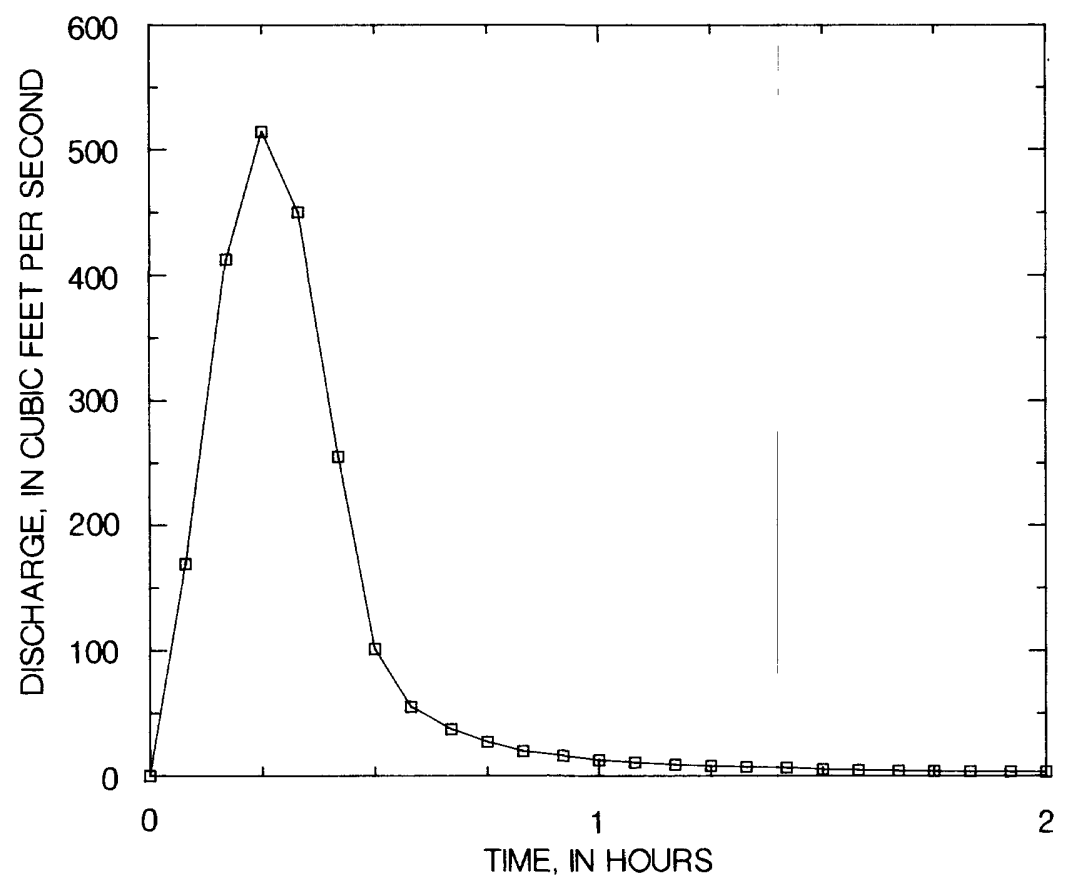

Figure 7.--Unit hydrograph computed from observed data at Crane Creek Tributary at Columbia, August 18, 1986, with a 1.00 -inch precipitation excess duration of 5 minutes and lag time of 0.32 hours 
(3) An average unit hydrograph, with a duration equal to the recording interval, is computed by aligning the peaks and averaging the discharge ordinates of the final selection of unit hydrographs (fig. 8 and table 5). The correct timing of the center of mass of the average unit hydrograph is obtained by averaging the time of the center of mass of the individual unit hydrographs. The computed lag times for each event are also averaged to provide a mean basin lag time.

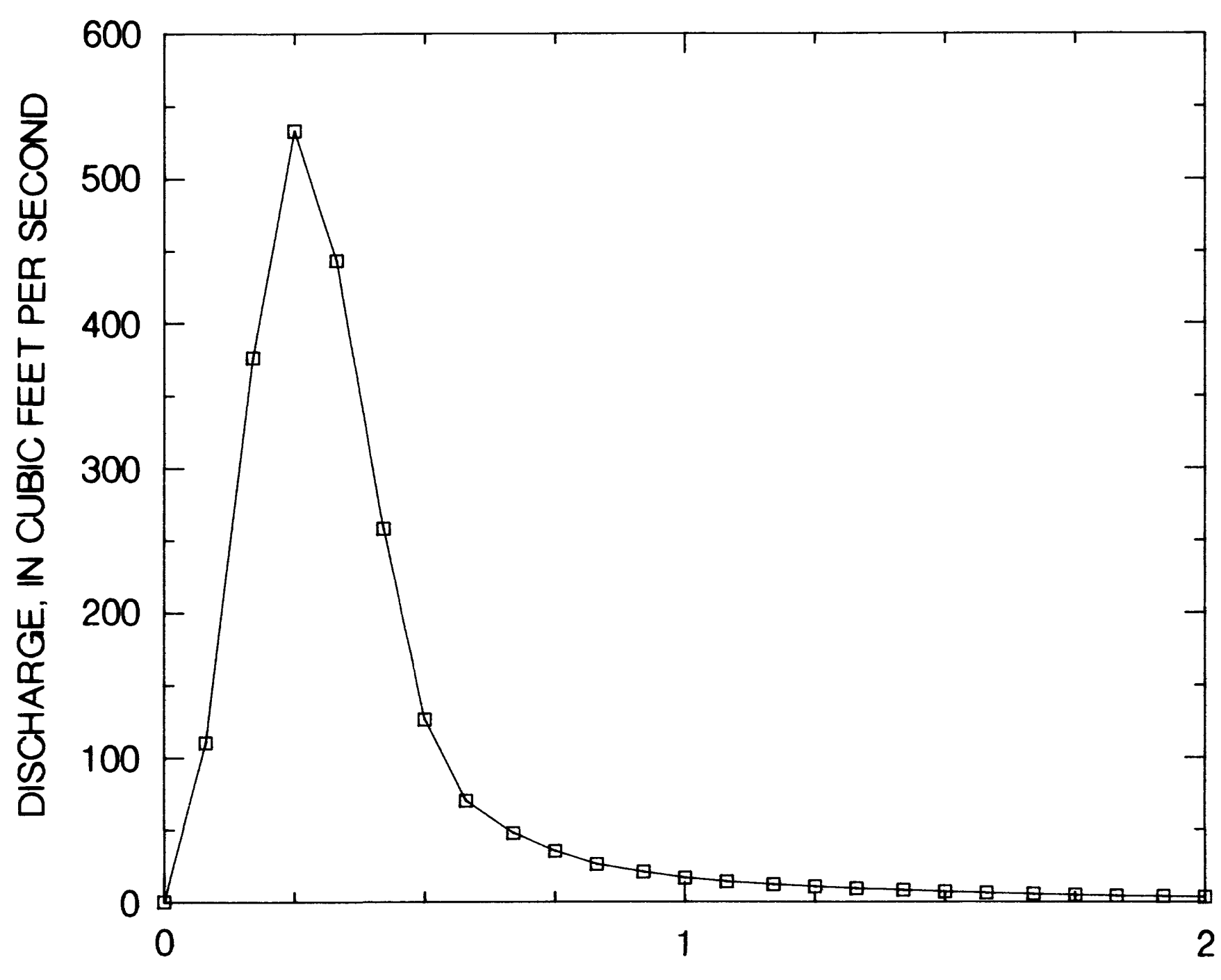

TIME, IN HOURS

Figure 8.--Average unit hydrograph with a precipitation-excess duration of 5 minutes for Crane Creek Tributary at Columbia. 
Table 5.-- Discharges at 5-minute intervals with peaks aligned for five unit hydrographs with date of occurrence and average unit hydrograph computed for Crane Creek tributary at Columbia (station no. 02167020)

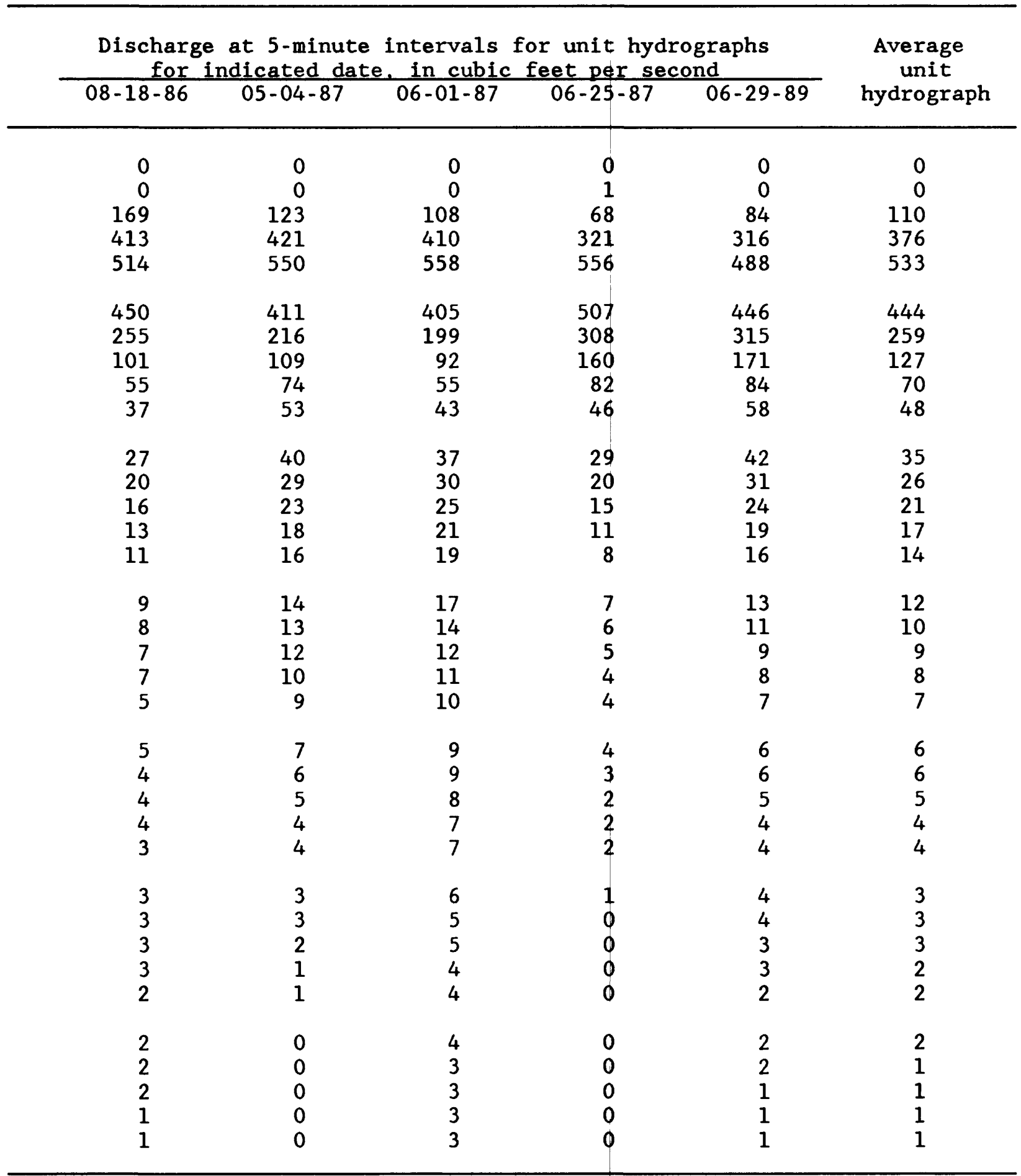


(4) The average unit hydrographs computed in step 3 are transformed to hydrographs having durations of one-fourth, one-third, one-half, and three-fourths of the average lag time computed in step 3 . This transformation is necessary because the unit hydrographs have been computed using 5- or 15-minute time intervals. To convert the average unit hydrograph to a more realistic duration, fractions of lag time were used. The fractional lag times are further adjusted to the nearest multiple of the original duration (recording interval). For example, if the original duration is 5 minutes and the average lag time is 0.7 hours ( 42 minutes), then one-fourth lag time is 10.5 minutes, which would be rounded to 10 minutes. One-third lag time is 14 minutes, which would be rounded to 15 minutes. One-half 1 ag time is 21 minutes, which would be rounded to 20 minutes. Three-fourths lag time is 31.5 minutes, which would be rounded to 30 minutes. The transformed unit hydrographs will have durations of 2 times, 3 times, 4 times, and 6 times the duration of the original unit hydrograph. The transformation of a short duration unit hydrograph to a long duration unit hydrograph (for instance, a 5-minute duration to a 20-minute duration) can be accomplished through the use of the following equations:

$\frac{D / \Delta t}{2}$
3
4
$n$

EQUATION
$\operatorname{TUHD}(t)=(1 / 2)[\operatorname{TUH}(t)+\operatorname{TUH}(t-1)]$
$\operatorname{TUHD}(t)=(1 / 3)[\operatorname{TUH}(t)+\operatorname{TUH}(t-1)+\operatorname{TUH}(t-2)]$
$\operatorname{TUHD}(t)=(1 / 4)[\operatorname{TUH}(t)+\operatorname{TUH}(t-1)+\operatorname{TUH}(t-2)+\operatorname{TUH}(t-3)]$
$\operatorname{TUHD}(t)=(1 / n)[\operatorname{TUH}(t)+\operatorname{TUH}(t-1) \ldots \operatorname{TUH}(t-n-1)]$,

where $\Delta t$ is recording interval, (original unit hydrograph has a duration equal to $\Delta t$ );

$D$ is design duration of the unit hydrograph, (must be a multiple of $\Delta t$ );

$\operatorname{TUHD}(t)$ is ordinate of the design unit hydrograph at time $t$; and

$\operatorname{TUH}(t), \operatorname{TUH}(t-1)$, and so forth, are ordinates of the original unit hydrograph at times $t, t-1, t-2$, and so forth.

Actual duration of rainfall excess for a storm may be defined as the time during which precipitation falls at a rate greater than existing infiltration capacity. A design duration, rather than actual duration, was used in this study because the actual duration of rainfall excess is highly variable. The design duration is expressed as a fractional part of lag time, such as one-fourth, one-third, one-half, or three-fourths of the average lag time computed in step 3. As discussed later in this report, the design duration for each dimensionless hydrograph that most closely reproduced the observed hydrographs in each region was chosen. 
(5) The one-fourth, one-third, one-half, and three-fourths lag time duration hydrographs are reduced to dimensionless terms by dividing the time coordinates of the unit hydrographs by lag time and the discharge coordinates by peak discharge. The results of this step are illustrated in figure 9.

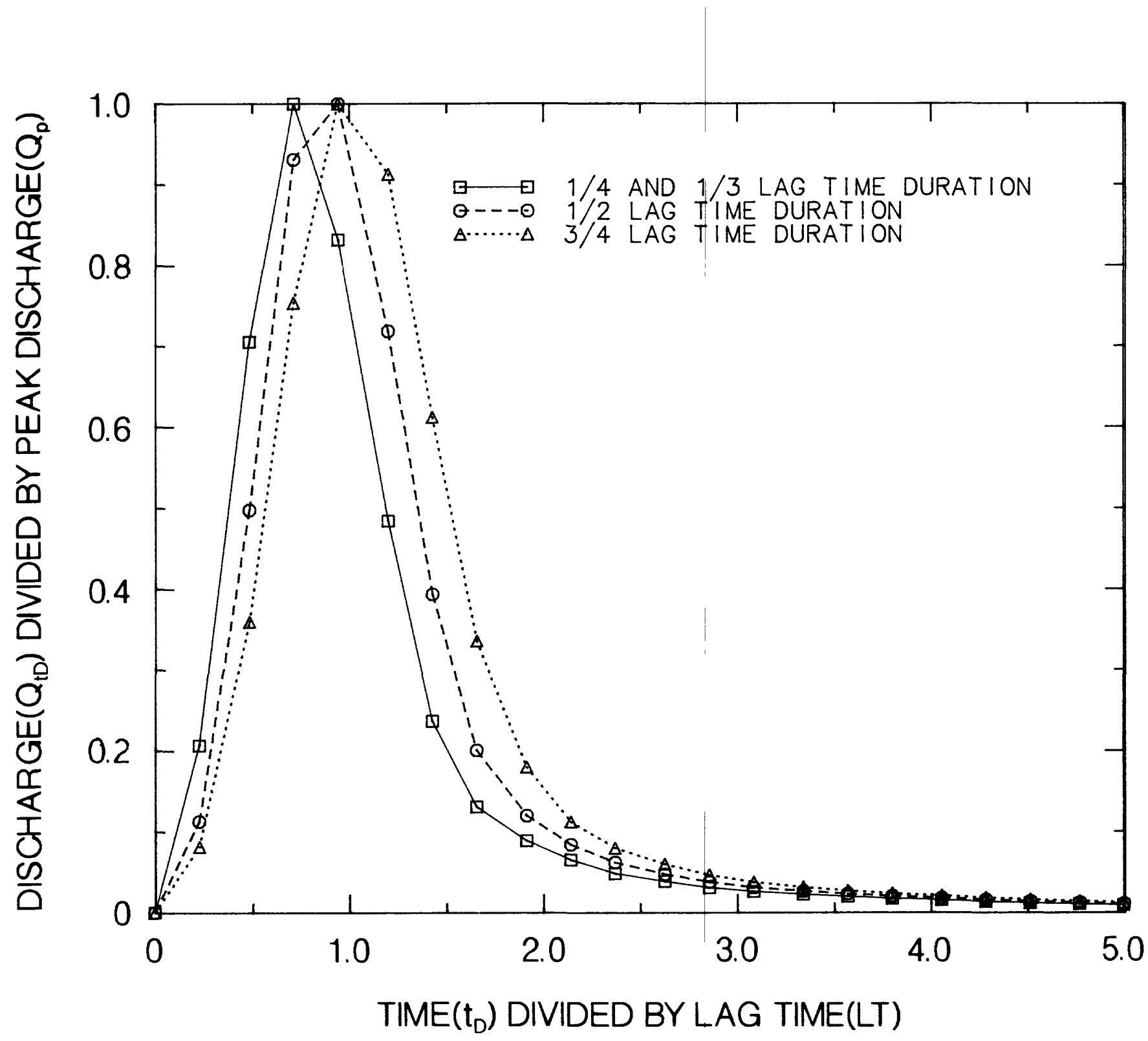

Figure 9.--One-fourth-, one-third-, one-half-, and three-fourths-lag time duration dimensionless hydrographs for Crane Creek Tributary at Columbia. 
(6) An average dimensionless hydrograph is computed by averaging the dimensionless hydrographs at the station in one or more regions. The average hydrographs were computed by aligning the peaks and averaging each ordinate of the discharge ratio, $Q_{t D} / Q_{p}$. The average one-fourth-lag time duration dimensionless hydrograph for the lower Coastal Plain province and the range of the data from the 8 stations from which it was computed are illustrated in figure 10 .

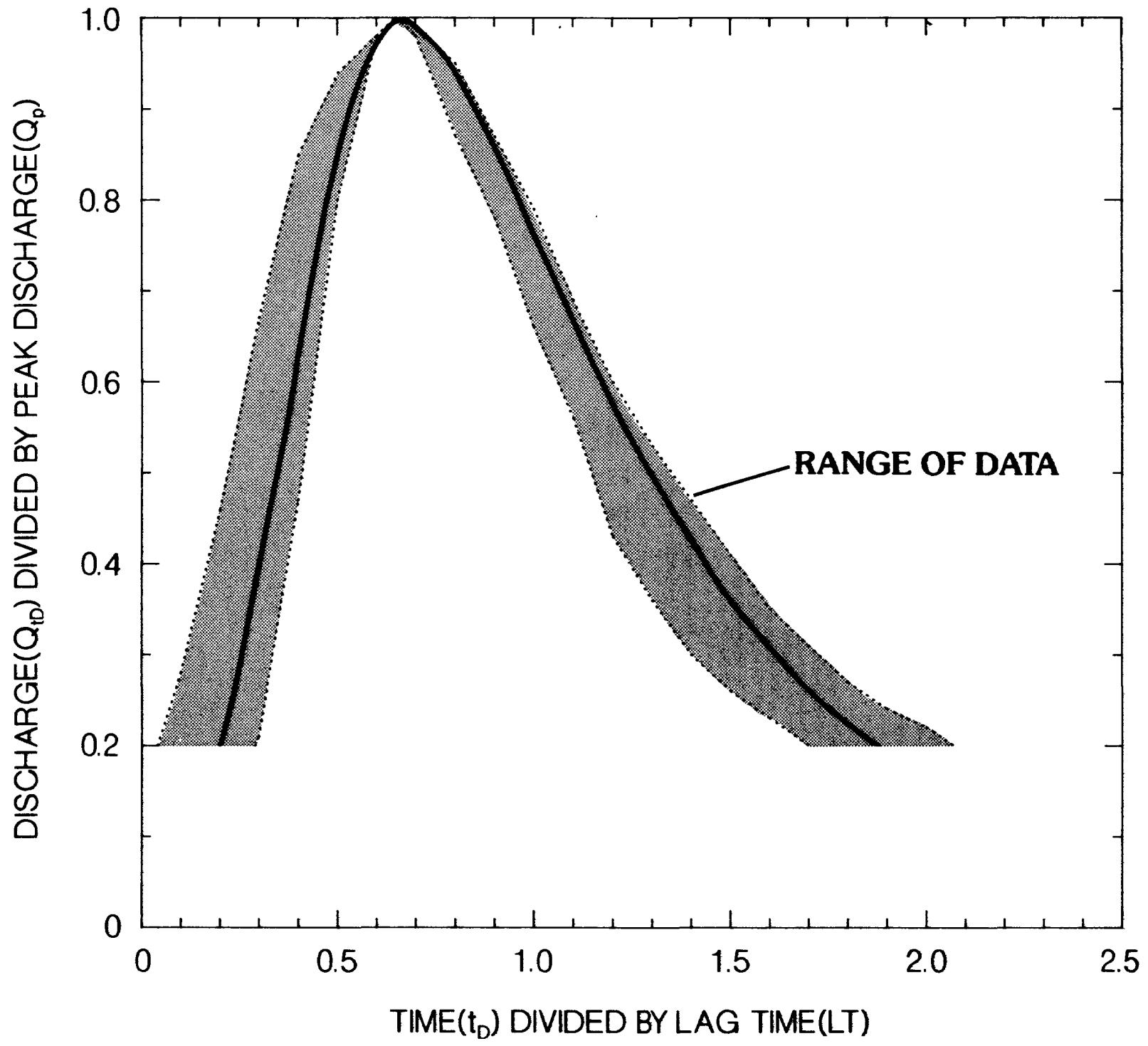

Figure 10.--Average one-third-lag time dimensionless hydrograph for the lower Coastal Plain and the range of data from the eight stations from which it was computed 
(7) The most representative hydrograph shape for each region is then determined by computing the standard error of hydrograph widths estimated by applying the observed peak discharges and average basin lag times to the various regional dimensionless hydrographs with durations of one-fourth, one-third, one-half, and threefourths lag time. The standard error of the estimate of the width comparisons is based on the mean-square difference between the observed and estimated hydrograph widths at 50 and 75 percent of peak stormflow. An example of these comparisons is shown in figure 11 .
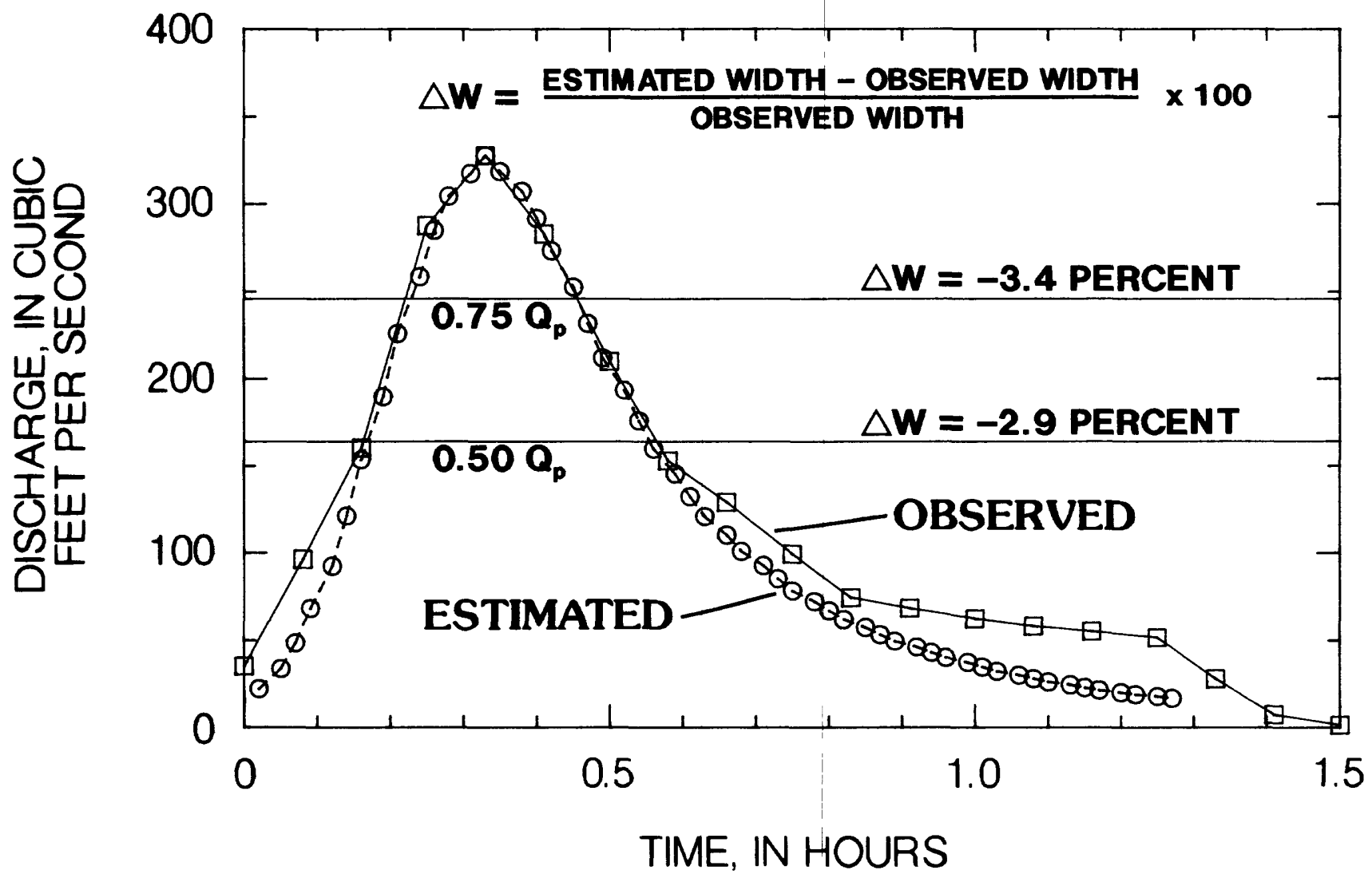

Figure 11.--Estimated runoff hydrograph using observed peak flow and average basin lag time, and the observed runoff hydrograph showing width comparisions at 50 and 75 percent of peak discharge for Sunnyside Canal at Orangeburg, November 10, 1987. 
(8) Further investigation showed that some improvement in the results of step 7 could be obtained by making a correction to lag time based on a regression analysis of runoff volume. The correction factor is calculated as the ratio of the runoff volume predicted by the volume regression equations to the runoff volume estimated using the appropriate dimensionless hydrograph and unadjusted lag times. The average basin lag time is multiplied by the correction factor to obtain an "adjusted" lag time.

\section{Adjusting Average Basin Lag Time for Correct Runoff Volume}

The procedures used to derive the dimensionless hydrographs are shape-oriented rather than volume-oriented. The overall shape is simply arithmetically averaged to arrive at each regional hydrograph. The volume of runoff associated with a dimensionless hydrograph can be estimated by an equation of the form:

$$
V=(\mathrm{K})(\mathrm{Qp})^{1.0}(\mathbf{L T})^{1.0}(\mathrm{~A})^{-1.0}
$$

where $\mathrm{V}$ is the runoff volume, in inches;

$\mathrm{K}$ is the volume conversion constant;

Qp is the peak discharge, in cubic feet per second;

LT is the lag time, in hours; and

$A$ is the drainage area, in square miles.

The constant $(K)$ is calculated by first extrapolating the rising and falling limbs of each dimensionless hydrograph to a discharge ratio of zero. The discharge-ratio ordinates are then summed at time-ratio intervals of 0.05 . This sum is then multiplied by time and drainage area conversion constants in order to provide volume in watershed inches.

Regression equations to estimate volume were also computed using the same data set used to develop the dimensionless hydrograph shapes. The volumes resulting from the regression equations did not exactly match those obtained using the dimensionless hydrographs, because the regression equations for volume allow the coefficients for all three variables (Qp, LT, and $A$ ) to vary individually as they relate to observed runoff volumes. Therefore, the volumes obtained using the regression technique are probably more reliable due to the flexibility of the components. The regression volume results were therefore used as a basis for adjusting the dimensionless hydrograph parameters. The basic shape of the hydrograph was then preserved while using volume as a normalizing variable. A lag-time correction factor (F) was computed by calculating the ratio of regression to dimensionless volumes. The factor was then applied to the average basin lag time prior to estimating a flood hydrograph. 
Calibration results for the South Carolina and Georgia basins used in this report are summarized in table 6 . The information for the Georgia stations was taken from Inman (1988). Average standard errors of estimate (in percent) are presented for peak discharges at each study site.

\section{PEAK-DISCHARGE-FREQUENCY RELATIONS AT GAGED URBAN BASINS}

Peak discharges, from the Pearson Type III analyses, having recurrence intervals of $2,5,10,25,50,100$, and 500 years from both the long-term syntheses and observed data are presented in table 7 . In most cases, the data in table 7 and computations of discharges for rural basins of equivalent recurrence interval illustrate the tendency for urban and rural curves to converge slightly from smaller to larger recurrence intervals due to urbanization effects which are more pronounced for minor flood events than for major ones. The mean flood ratios for the observed urban flood discharge (UQ) to the estimated rural flood discharge (RQ), by province, for the 2 - and 100-year flood frequencies is shown below:

\section{Province}

Piedmont

Upper Coastal Plain

Lower Coastal Plain
$\mathrm{UQ}_{2} / \mathrm{RQ}_{2}$ flood ratio

2.9

13.5

3.7
$\mathrm{UQ}_{100} / \mathrm{RQ}_{100}$ flood ratio

2.4

8.5

2.8

The upper Coastal Plain ratio values are unusually high because of the small rural discharges obtained for equivalent basin sizes and frequencies. The relatively small rural peak discharges that are typical of the upper Coastal Plain, are due, in part, to the extremely sandy soils that have high infiltration rates and low runoff potentials. 
Table 6.--Optimized rainfall-runoff model parameters and standard error of estimate for peak discharge for each study basin

[Parameters DRN and TP/TC were assigned fixed values of 1.00 and 0.50 , respectively, for all stations and were not optimized. EVC was also set to values shown and not optimized. Augusta and Savannah station parameter values are from Inman (1988). Parameter symbols are defined in table 4.]

City name, and station number

PSP KSAT RGF BMSM EVC RR KSW $\quad$ TC $\quad$ EIA SEE $^{1}$

\begin{tabular}{|c|c|c|c|c|c|c|c|c|c|c|}
\hline $\begin{array}{l}\text { Allendale } \\
02176380\end{array}$ & 7.47 & 0.225 & 59.7 & 2.25 & 0.75 & 0.778 & 2.34 & 62 & 0.084 & \pm 16.6 \\
\hline $\begin{array}{l}\text { Anderson } \\
02187260 \\
02187268\end{array}$ & $\begin{array}{l}.54 \\
.44\end{array}$ & $\begin{array}{l}.050 \\
.079\end{array}$ & $\begin{array}{l}52.1 \\
30.0\end{array}$ & $\begin{array}{l}3.10 \\
2.56\end{array}$ & $\begin{array}{l}.75 \\
.75\end{array}$ & $\begin{array}{l}.750 \\
.950\end{array}$ & $\begin{array}{l}.160 \\
1.91\end{array}$ & $\begin{array}{r}28 \\
156\end{array}$ & $\begin{array}{l}.160 \\
.140\end{array}$ & $\begin{array}{l} \pm 28.8 \\
\pm 27.2\end{array}$ \\
\hline $\begin{array}{l}\text { Augusta } \\
02196570 \\
02196605 \\
02196760 \\
02196850\end{array}$ & $\begin{array}{l}2.73 \\
2.38 \\
9.76 \\
5.15\end{array}$ & $\begin{array}{l}.148 \\
.210 \\
.215 \\
.132\end{array}$ & $\begin{array}{c}13.0 \\
11.1 \\
16.8 \\
5.59\end{array}$ & $\begin{array}{r}4.38 \\
2.43 \\
3.65 \\
11.5\end{array}$ & $\begin{array}{l}.75 \\
.75 \\
.75 \\
.75\end{array}$ & $\begin{array}{l}.941 \\
.950 \\
.727 \\
.949\end{array}$ & $\begin{array}{l}.800 \\
.250 \\
.550 \\
.200\end{array}$ & $\begin{array}{l}45 \\
25 \\
50 \\
10\end{array}$ & $\begin{array}{l}.149 \\
.166 \\
.170 \\
.219\end{array}$ & $\begin{array}{l} \pm 32.9 \\
\pm 21.4 \\
\pm 23.8 \\
\pm 27.2\end{array}$ \\
\hline $\begin{array}{l}\text { Columbia } \\
02162093 \\
02167020 \\
02168845 \\
02169505 \\
02169568\end{array}$ & $\begin{array}{l}5.50 \\
1.34 \\
2.40 \\
4.00 \\
1.99\end{array}$ & $\begin{array}{l}.104 \\
.327 \\
.094 \\
.203 \\
.438\end{array}$ & $\begin{array}{l}58.4 \\
23.9 \\
55.0 \\
65.7 \\
35.4\end{array}$ & $\begin{array}{l}4.70 \\
4.14 \\
6.10 \\
3.61 \\
3.30\end{array}$ & $\begin{array}{l}.75 \\
.75 \\
.75 \\
.75 \\
.75\end{array}$ & $\begin{array}{l}.945 \\
.816 \\
.927 \\
.900 \\
.948\end{array}$ & $\begin{array}{l}.744 \\
.104 \\
.535 \\
.226 \\
1.19\end{array}$ & $\begin{array}{l}80 \\
18 \\
28 \\
23 \\
35\end{array}$ & $\begin{array}{l}.400 \\
.270 \\
.209 \\
.356 \\
.281\end{array}$ & $\begin{array}{l} \pm 14.8 \\
\pm 23.4 \\
\pm 23.9 \\
\pm 19.1 \\
\pm 15.3\end{array}$ \\
\hline $\begin{array}{l}\text { Florence } \\
02131130\end{array}$ & 1.43 & .276 & 20.3 & 8.27 & .75 & .945 & .520 & 28 & .232 & \pm 26.2 \\
\hline $\begin{array}{l}\text { Greenville } \\
02160325 \\
02163940 \\
02164011\end{array}$ & $\begin{array}{r}.52 \\
2.64 \\
.75\end{array}$ & $\begin{array}{l}.084 \\
.108 \\
.099\end{array}$ & $\begin{array}{l}32.8 \\
39.6 \\
27.4\end{array}$ & $\begin{array}{l}3.00 \\
3.53 \\
3.11\end{array}$ & $\begin{array}{l}.75 \\
.75 \\
.75\end{array}$ & $\begin{array}{l}.750 \\
.916 \\
.950\end{array}$ & $\begin{array}{r}1.36 \\
.221 \\
.976\end{array}$ & $\begin{array}{r}165 \\
23 \\
50\end{array}$ & $\begin{array}{l}.128 \\
.080 \\
.260\end{array}$ & $\begin{array}{l} \pm 24.5 \\
\pm 35.3 \\
\pm 18.1\end{array}$ \\
\hline $\begin{array}{l}\text { Greenwood } \\
02166975\end{array}$ & .74 & .091 & 48.3 & 4.96 & .75 & .900 & 1.36 & 71 & .171 & \pm 17.9 \\
\hline $\begin{array}{l}\text { Myrtle Beach } \\
02110740\end{array}$ & .76 & .105 & 66.4 & 2.70 & .77 & 948 & 1.40 & 56 & 227 & \pm 23.0 \\
\hline
\end{tabular}


Table 6.--Optimized rainfal1-runoff model parameters and standard error of estimate for peak discharge for each study basin.--Continued

[Parameters DRN and TP/TC were assigned fixed values of 1.00 and 0.50 , respectively, for all stations and were not optimized. EVC was also set to values shown and not optimized. Augusta and Savannah station parameter values are from Inman (1988). Parameter symbols are defined in table 4.]

City name, and station number

$\begin{array}{llllllllll}\text { PSP } & \text { KSAT } & \text { RGF } & \text { BMSM } & \text { EVC } & \text { RR } & \text { KSW } & \text { TC } & \text { EIA } & \text { SEE }^{1}\end{array}$

North Charleston

0217206930
$0.160 \quad 75.0 \quad 7.34$
0.77
0.874
0.456
17
$0.222 \pm 15.4$

Orangeburg

02173491

02173495

$3.89 \quad .146 \quad 42.3$

4.32

.75

$.937 \quad .396$

$31.273 \pm 23.2$

02174240

$1.67 \quad .150 \quad 42.3$

4.99

$.760 \quad .320$

$21.380 \quad \pm 23.9$

Savannah

02203542

02203543

02203544

$\begin{array}{ccc}1.20 & .135 & 7.42 \\ 2.33 & .150 & 18.2 \\ 2.05 & .150 & 11.3\end{array}$

$\begin{array}{lll}2.14 & .77 \quad .956\end{array}$

.884

$\begin{array}{lll}65 & .167 \quad \pm 26.4\end{array}$

Spartanburg

$\begin{array}{lrrrrrrrrrr}02156260 & .40 & .067 & 42.2 & 2.03 & .75 & .650 & .217 & 15 & .558 & \pm 15.7 \\ 02159785 & 1.44 & .119 & 18.9 & 3.55 & .75 & .950 & .680 & 45 & .020 & \pm 30.4\end{array}$

Sumter

02135518

$3.24 \quad .234 \quad 16$

8.29

$.77 \quad .912$

$2.70 \quad 160$

$.217 \pm 18.4$

$\begin{array}{lll}2.05 & .150 & 11.3\end{array}$

6.32

$.77 \quad .948$

1.75

$105.198 \pm 19.1$

Rock Hill

02145940

02146100

$\begin{array}{lll}.40 & .118 & 45.1 \\ .55 & .079 & 75.0\end{array}$

3.97

3.50

.75

$.950 \quad .850$

$62 \quad .150 \quad \pm 29.1$

$4.12 \quad .75$

.908

1.00
.465

$\begin{array}{lll}78 & .173 \pm 30.2\end{array}$

$\begin{array}{lllll}.947 & .465 & 52 & .206 & \pm 29.8\end{array}$

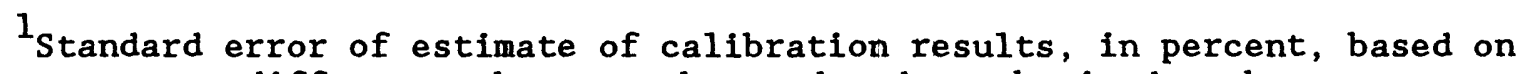
the mean-square differences between observed and synthesized peaks. 
Table 7. - -Flood-frequency data from long-term synthesis for urban gaging stations in South Carolina and Georgia, and from observed data in North Carolina

$$
\text { [ - - indicates no data] }
$$

Map-location

symbo1 for

stations used

for long-term

City name, synthesis (fig. 3)

and station Evapo- Rain-

Peak discharge for indicated recurrence interval,

number

ration fall in cubic feet per second

\begin{tabular}{ccccccl}
\multicolumn{8}{c}{ in cubic feet } & per & second \\
\hline 2 & 5 & 10 & 25 & 50 & 100 & 500 \\
year & year & year & year & year & year & year
\end{tabular}

Allendale

02176380

$308 \quad 497$

695

$958 \quad 1,930$

Anderson

02187260

02187268

$M \quad D$

687

$1,060 \quad 1,290$

1,580

1,780

1,970

2,390

616

9521,210

1,560

1,850

2,170

2,990

Augusta

02196570

02196605

02196760

02196850

$\mathrm{J}$
$\mathrm{J}$
$\mathrm{J}$
$\mathrm{J}$

182

300

383

492

576

660

859

B

640

280

1,050

1,390

1,900

2,340

2,850

4,300

B

232

372

474

612

921

722

8361,120

Columbia

02162093

02167020

02168845

02169505

02169568

$\begin{array}{ll}\mathrm{K} & \mathrm{C} \\ \mathrm{K} & \mathrm{C} \\ \mathrm{K} & \mathrm{C} \\ \mathrm{K} & \mathrm{C} \\ \mathrm{K} & \mathrm{C}\end{array}$

1,400

2,090

2,510

3, 010

3,340

3,660

4,310

161

109

260

323

396

445

491

584

1,120

1,660

237

307

359

412

536

378

596

1,980

2., $310 \quad 2,530$

2,720

3,090

Charlotte ${ }^{1}$

02146300

02146500

02146600

02146700

$--$

3,200

4,650

5,650

94

1,100

$1,260 \quad 1,630$

- - $\quad-$ -

4,360

5,950

7,000

6,960

7,970

$8,99011,500$

$\cdots \quad \cdots$

2,700

3,880

4,700

8,330

$9,33010,30012,700$

925

1,260

1,470

5,760

$6,560 \quad 7,390 \quad 9,380$

1,750

$1,950 \quad 2,160$

2,630

Florence

02131130

H C

555

951

1,220

1,560

1,810

2,050

2,580

Greenville

02160325

02163940

02164011

$\begin{array}{ll}M & D \\ M & D \\ M & D\end{array}$

2,050
315

3,210

4,110

5,370

6,410

$7,54010,500$

1,050

1,700

698

$\begin{array}{llll}905 & 1,060 & 1,220 & 1,580\end{array}$

D

2,170

2,820

3,330

$3,860 \quad 5,210$ 
Table 7.--Flood-frequency data from long-term synthesis for urban gaging stations in South Carolina and Georgia, and from observed data in North Carolina--Continued

\begin{tabular}{|c|c|c|c|c|c|c|c|c|c|}
\hline \multirow{2}{*}{$\begin{array}{l}\text { City name, sy } \\
\text { and station } \\
\text { number }\end{array}$} & \multirow{2}{*}{\multicolumn{2}{|c|}{$\begin{array}{l}\text { Map-location } \\
\text { symbol for } \\
\text { stations used } \\
\text { for long-term } \\
\text { ynthesis (fig. 3) } \\
\text { Evapo- Rain- } \\
\text { ration fall }\end{array}$}} & \multicolumn{7}{|c|}{$\begin{array}{c}\text { Peak discharge for indicated } \\
\text { recurrence interval, } \\
\text { in cubic feet per second }\end{array}$} \\
\hline & & & $\begin{array}{c}2 \\
\text { year }\end{array}$ & $\begin{array}{c}5 \\
\text { year }\end{array}$ & $\begin{array}{l}10 \\
\text { year }\end{array}$ & $\begin{array}{l}25 \\
\text { year }\end{array}$ & $\begin{array}{l}50 \\
\text { year }\end{array}$ & $\begin{array}{l}100 \\
\text { year }\end{array}$ & $\begin{array}{l}500 \\
\text { year }\end{array}$ \\
\hline $\begin{array}{l}\text { Greenwood } \\
02166975\end{array}$ & $I, M$ & $B, D$ & 288 & 446 & 561 & 718 & 846 & 980 & 1,320 \\
\hline $\begin{array}{l}\text { Myrtle Beach } \\
02110740\end{array}$ & $\mathbf{G}$ & A & 296 & 478 & 605 & 771 & 897 & 1,020 & 1,330 \\
\hline $\begin{array}{l}\text { North Charles } \\
0217206930\end{array}$ & $\begin{array}{r}\text { ston } \\
\text { G }\end{array}$ & A & 85 & 136 & 178 & 243 & 300 & 365 & 555 \\
\hline $\begin{array}{l}\text { Orangeburg } \\
02173491 \\
02173495 \\
02174240\end{array}$ & $\begin{array}{l}\mathrm{H} \\
\mathrm{H} \\
\mathrm{H}\end{array}$ & $\begin{array}{l}\text { B, C } \\
\text { B,C } \\
\text { B,C }\end{array}$ & $\begin{array}{l}148 \\
554 \\
428\end{array}$ & $\begin{array}{l}232 \\
852 \\
730\end{array}$ & $\begin{array}{r}290 \\
1,040 \\
952\end{array}$ & $\begin{array}{r}362 \\
1,260 \\
1,250\end{array}$ & $\begin{array}{r}416 \\
1,410 \\
1,480\end{array}$ & $\begin{array}{r}470 \\
1,550 \\
1,730\end{array}$ & $\begin{array}{r}600 \\
1,870 \\
2,320\end{array}$ \\
\hline $\begin{array}{l}\text { Savannah } \\
02203542 \\
02203543 \\
02203544\end{array}$ & $\begin{array}{l}\mathrm{F} \\
\mathrm{F} \\
\mathrm{F}\end{array}$ & $\begin{array}{l}\text { A } \\
\text { A } \\
\text { A }\end{array}$ & $\begin{array}{l}341 \\
250 \\
101\end{array}$ & $\begin{array}{l}525 \\
419 \\
160\end{array}$ & $\begin{array}{l}652 \\
542 \\
198\end{array}$ & $\begin{array}{l}815 \\
706 \\
244\end{array}$ & $\begin{array}{l}938 \\
834 \\
278\end{array}$ & $\begin{array}{r}1,060 \\
965 \\
310\end{array}$ & $\begin{array}{r}1,350 \\
1,280 \\
380\end{array}$ \\
\hline $\begin{array}{l}\text { Spartanburg } \\
02156260 \\
02159785\end{array}$ & $\begin{array}{l}M, K \\
M, K\end{array}$ & $\begin{array}{l}D, E \\
D, E\end{array}$ & $\begin{array}{l}567 \\
154\end{array}$ & $\begin{array}{l}831 \\
266\end{array}$ & $\begin{array}{r}1,000 \\
349\end{array}$ & $\begin{array}{r}1,210 \\
460\end{array}$ & $\begin{array}{r}1,360 \\
545\end{array}$ & $\begin{array}{r}1,500 \\
635\end{array}$ & $\begin{array}{r}1,810 \\
852\end{array}$ \\
\hline $\begin{array}{l}\text { Sumter } \\
02135518\end{array}$ & $\mathrm{H}$ & C & 334 & 595 & 792 & 1,060 & 1,270 & 1,490 & 2,020 \\
\hline $\begin{array}{l}\text { Rock Hill } \\
02145940 \\
02146100\end{array}$ & $\begin{array}{l}\mathrm{K} \\
\mathrm{K}\end{array}$ & $\begin{array}{l}\mathbf{E} \\
\mathbf{E}\end{array}$ & $\begin{array}{l}966 \\
530\end{array}$ & $\begin{array}{r}1,410 \\
788\end{array}$ & $\begin{array}{r}1,690 \\
955\end{array}$ & $\begin{array}{l}2,020 \\
1,160\end{array}$ & $\begin{array}{l}2,240 \\
1,310\end{array}$ & $\begin{array}{l}2,450 \\
1,450\end{array}$ & $\begin{array}{l}2,890 \\
1,770\end{array}$ \\
\hline
\end{tabular}

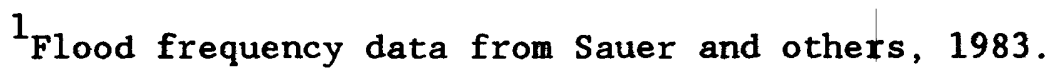




\section{PEAK-DISCHARGE-FREQUENCY RELATIONS AT UNGAGED URBAN BASINS}

Urban peak discharges at gaged sites were related to a variety of basin characteristics using multiple regression techniques in order to provide a method for predicting flood peaks of specific recurrence interval at ungaged sites in South Carolina. Various combinations of drainage area (A), mainchannel slope (S) and length (L), total impervious area (TIA), basin development factor (BDF), rural discharge $\left(R_{T}\right)$ and 2-year 2-hour rainfall amounts (RI2) were used as explanatory variabfes. A qualitative explanatory variable, which indicated location by physiographic province, also was tested. A listing of the stations and basin characteristics used in regionalization analyses is presented in table 8 .

The regional analysis resulted in the 7 regression equations 1 isted in table 9 that can be used to estimate peak discharges of specific recurrence intervals for small urban streams in South Carolina. The standard error of regression, coefficient of determination, and standard error of prediction for each equation are also listed in table 9. Three explanatory variables (drainage area, total impervious area, and rural discharge) provided the best fit of observed data. All three variables were found to be statistically significant at the 0.01 level in all equations.

\section{Comparison to Nationwide Urban Peak-Discharge Equations}

A comparison was made between the 2-,25-, and 100-year floods, estimated from equations developed in this study, and flood discharges estimated from the nationwide 7-parameter equations developed by Sauer and others (1983). The nationwide equations generally underpredicted floods in South Carolina. The ratio of the estimate of peak discharge using the urban equations developed for South Carolina to the estimate using the nationwide 7 -parameter equations was computed for each gaging site. The mean ratios for the 2-, 25-, and 100-year floods were $1.39,1.50$, and 1.44, respectively. The standard error of prediction for the 100-year flood using the 7 -parameter nationwide equations was \pm 65.3 percent.

\section{Sensitivity Analysis}

Errors in measurement or judgment may occur when determining values for the explanatory variables (A, TIA, and $\mathbf{R Q}_{\mathrm{T}}$ ). Therefore, a sensitivity analysis was made to illustrate the effects of errors in the explanatory variables on the resultant computations of peak discharge. The mean values for each explanatory variable were substituted into the 7 regression equations and each explanatory variable was varied by 5 -percent increments from -50 to +50 percent, while holding the other variables constant. The percentage change in the explanatory variable was then plotted against the percentage change in the computed peak discharge. The results are presented in figure 12. Only the $\mathrm{UQ}_{2}, \mathrm{UQ}_{25}$, and $\mathrm{UQ}_{100}$ plots are shown due to similarities between the plots. 


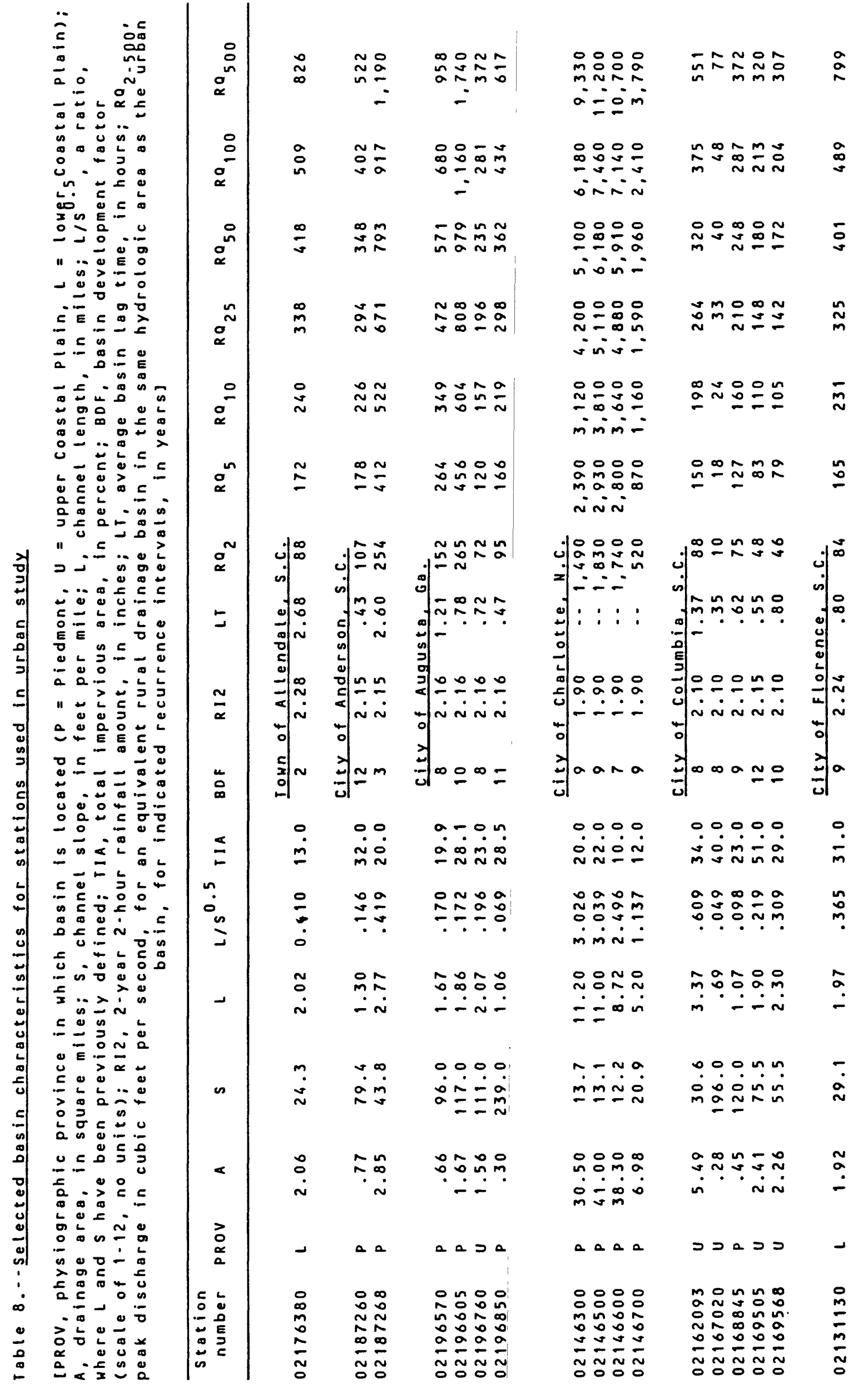




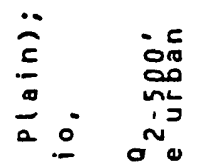

-

क 020

㝳论

\$。

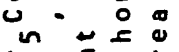

$\therefore$ 造 $=\frac{1}{0}$

X $E=$

그으.

"...

is $>$ 正

-

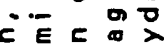

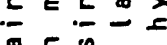

a

is

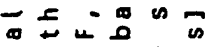

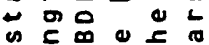

\% व 0

ن -

농ㄷㄴ

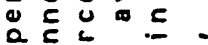

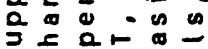

" 0 c 5

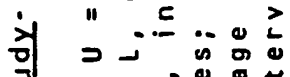

…로

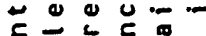

드응

EE

느응

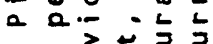

11

a

CEE

D $5-$ -

$+\infty=2$

U⿺辶⿻

- 0 =

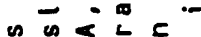

-

$=$ ฮㄴํำ

क

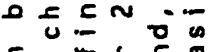

ᄃ

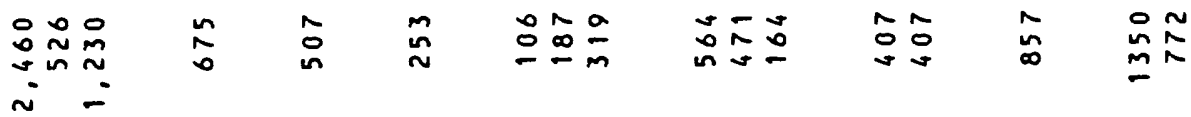
$\stackrel{\circ}{\circ}$

늠

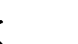

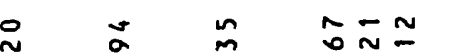

aa

in

$\sim$

$-n$

$\underset{m}{N} \stackrel{n}{m}$

$\frac{v}{m} \frac{v}{m}$

a

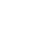

i̊n

$\because m$

$\underset{n}{n} \equiv$

$=\quad$ iñ

온

$m \underset{\infty}{\sim} \mathfrak{m}$

min =

$\approx N$

$\tilde{N}$

$\stackrel{m}{*} \quad \approx \infty$

$\stackrel{n}{\infty}$

스요

$m \sim 0 m$

-

$\stackrel{0}{\circ}$

$\stackrel{\circ}{a \sim} \stackrel{\sim}{\sim} \stackrel{\infty}{m}$

$\stackrel{\infty}{m}$

$\therefore$

品品

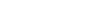

$x=200$

m $\simeq:$

$\cos 2$

$\stackrel{2}{2}$

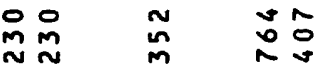

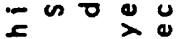

z..

$=\stackrel{0}{0} \overline{0}^{n}$

$=-3 \sim 0$

- E. 므

U $>\propto$

ᄃ

$>\infty a \ddot{2}$

은

$a$ is

도

ํ. 잉

車

实的

- $n \div$

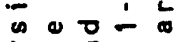

>

ट

- $=-10$

>닝

이이

a 0 告

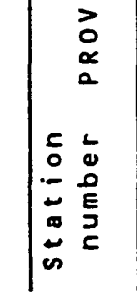

$a^{\sim}$

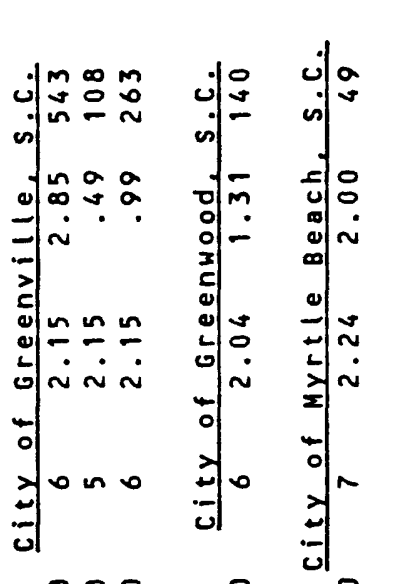

$\frac{\sim}{\infty}$

ㅇ․

$\dot{\sim} \tilde{N} \quad \dot{N} \quad \dot{n}$

$\because \quad \stackrel{m}{n} \quad$ m

$\because \quad \stackrel{n}{0} \div$

$\stackrel{\sim}{\sim} \stackrel{\sim}{0}$

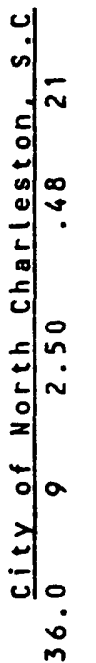

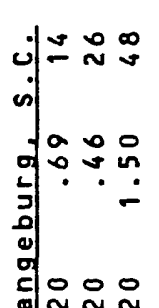

원용

oิ $\dot{\sim} \dot{\sim}$

$\div$

जी $\sim \infty$

000

$\stackrel{\sim}{\sim} \dot{m}$

nm

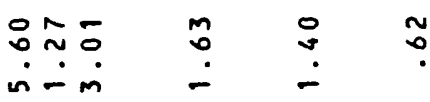

$\stackrel{2}{\infty}$

a. $\dot{m}$

$a$ a

$\because \frac{\sim}{\sim}$

in

in

$\underset{\sim}{\sim} \div$

$\infty 0 \bar{m}$

$\because 09$

mina

D. 00

ต) in in

$-\infty \dot{v} \dot{\sim}$

$=1 m a \alpha$

जा ma a

n $a$

$\because \because \ddot{n}$

o

ㄴํㅇ

?

$\cong \pm 0$

N

i -

m

$\sim$ n $\infty$

กิ

$\because \quad \infty$

ஸ

-

$\therefore$

20

-

in:

ma

인

$\frac{1}{N} \frac{1}{0}$

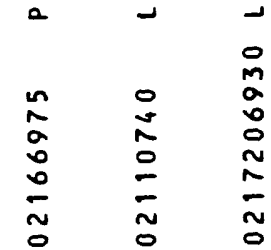

43

\begin{tabular}{|c|c|c|c|c|}
\hline 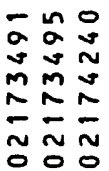 & 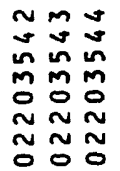 & $\begin{array}{ll}0 & n \\
n & \infty \\
\tilde{N} & \tilde{a} \\
0 & a \\
n & n \\
& \tilde{n} \\
0 & 0\end{array}$ & $\begin{array}{l}\frac{\infty}{n} \\
\approx \\
\approx \\
0\end{array}$ & $\begin{array}{ll}0 & 0 \\
0 & 0 \\
0 & 0 \\
n & 0 \\
0 & 0 \\
& 0 \\
0 & 0\end{array}$ \\
\hline
\end{tabular}
000 $a$

$a$

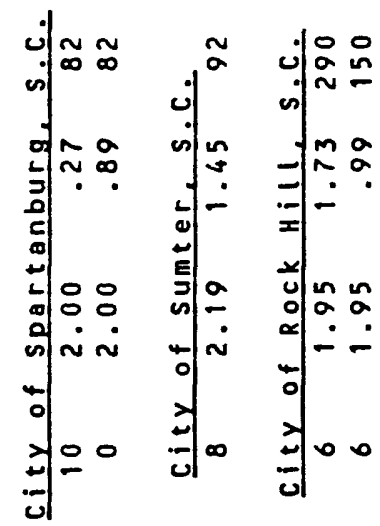

oㅇ 0 :

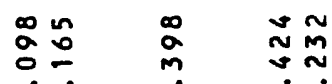
$\because \sim \quad \propto \quad 2 \infty$ $\because \therefore \quad \dot{\sim}$

$00 \quad \sim \quad \infty 0$

$\sim \sim \quad \therefore$ - $\dot{m}$ i $\sim \sim a \frac{n}{m}$

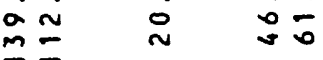


Table 9.--Equations for estimating peak discharges of urban streams in South Carolina

[UQ, peak discharge, in cubic feet per second, for an urban drainage basin; SER, standard error of regression, in percent; $\mathbf{R}^{2}$, coefficient of determination; SEP, standard error of prediction, in percent; $A$, drainage area, in square miles; TIA, total impervious area, in percent of total drainage area; $R Q_{2}-500$, peak discharge in cubic feet per second, for an equivalent rural arainage basin in the same hydrologic area as the urban basin, for indicated recurrence intervals, in years]

\begin{tabular}{|c|c|c|c|c|}
\hline $\begin{array}{c}\text { UQ } \\
\text { recurrence } \\
\text { interval } \\
\text { (years) } \\
\text { (percent) }\end{array}$ & Estimating equation & $\begin{array}{c}\text { SER } \\
\text { (percent) }\end{array}$ & $\mathrm{R}^{2}$ & SEP \\
\hline 2 & $1.36(\mathrm{~A})^{0.554}(\mathrm{TIA})^{1.241}\left(\mathrm{RQ}_{2}\right)^{0.323}$ & \pm 31.6 & 0.91 & \pm 34.3 \\
\hline 5 & $2.58(\mathrm{~A})^{0.544}(\mathrm{TIA})^{1.170}\left(\mathrm{RQ}_{5}\right)^{0.299}$ & \pm 29.0 & .91 & \pm 31.2 \\
\hline 10 & $3.77(\mathrm{~A})^{0.536}(\text { TIA })^{1.115}\left(\mathrm{RQ}_{10}\right)^{0.291}$ & \pm 27.1 & .92 & \pm 29.1 \\
\hline 25 & $5.84(\mathrm{~A})^{0.524}(\mathrm{TIA})^{1.041}\left(\mathrm{RQ}_{25}\right)^{0.284}$ & \pm 25.1 & .93 & \pm 26.8 \\
\hline 50 & $7.76(\mathrm{~A})^{0.514}(\text { TIA })^{0.987}\left(\mathrm{RQ}_{50}\right)^{0.283}$ & \pm 24.2 & .93 & \pm 25.8 \\
\hline 100 & $10.4(\mathrm{~A})^{0.506}(\mathrm{TIA})^{0.932}\left(\mathrm{RQ}_{100}\right)^{0.280}$ & \pm 24.0 & .93 & \pm 25.6 \\
\hline 500 & $18.8(\mathrm{~A})^{0.484}(\mathrm{TIA})^{0.800}\left(\mathrm{RQ}_{500}\right)^{0.281}$ & \pm 25.6 & .91 & \pm 28.5 \\
\hline
\end{tabular}

1

These equations should not be used if 1) drainage areas are less than $0.18 \mathrm{mi}^{2}$ or greater than $41 . \mathrm{mi}^{2}$, and 2) total impervious area is less than 10 percent or greater than 50 percent. 


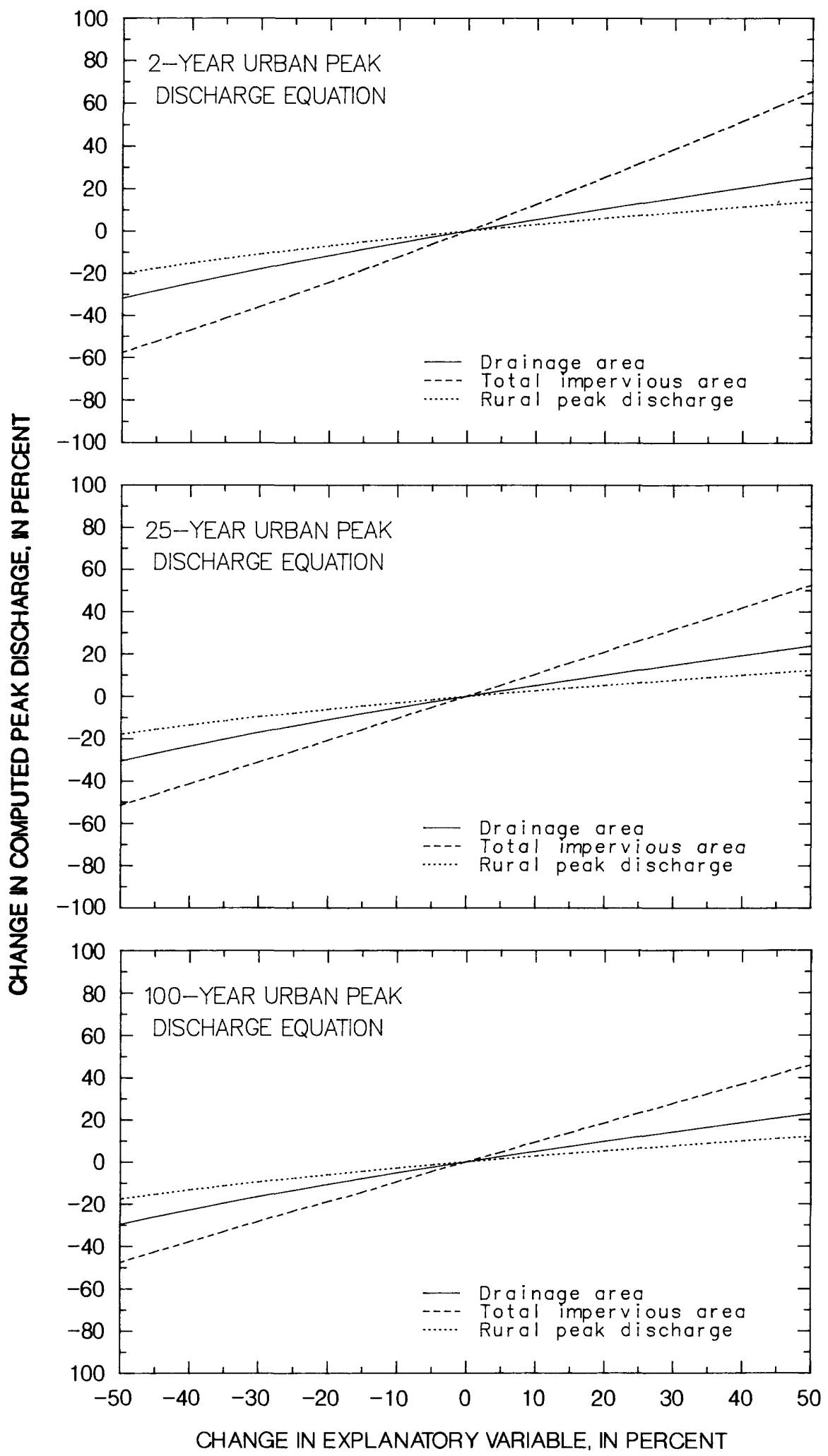

Figure 12.--Sensitivity of computed peak discharge to changes in the three explanatory variables for selected peak-discharge-frequency equations. 
The sensitivity of TIA decreases for floods with larger recurrence intervals. This happens because TIA tends to be less significant during large floods as soils become saturated and contribute increasingly to runoff. Also, flood peaks of highly developed basins may show less of an increase during large floods because of temporary storage behind culverts, bridges, and storm sewers.

\section{Tests for Multicollinearity and Bias}

Al1 significant variables were examined for multicollinearity using the variance inflation factor from the SAS output. The results showed that the predictive ability of the equations are not appreciably affected by multicollinearity.

Two tests for bias were performed, one for parameter bias and the other for geographical bias. Plots of residuals and each of the explanatory variables for all stations were made to check for variable bias. No consistent over-prediction or under-prediction was evident within the range of any of the variables. These plots also verified the linearity assumptions of the equations. The equations developed for South Carolina were found to be free of variable bias throughout the ranges of A, TIA, and $\mathbf{R Q}_{\mathbf{T}} \cdot$

The residuals, in percent, were plotted on a state map to determine if any geographical bias was present and no trends were noted. The inclusion of $\mathbf{R Q}_{\mathrm{T}}$ accounted for regional differences in hydrology, thereby reducing or eliminating much of the potential geographical bias.

\section{Application of Peak-Discharge-Frequency Equations}

The seven peak-discharge-frequency equations established in this study provide a means for estimating similar relations at ungaged urban basins in South Carolina. The application of the regression equations is quite simple, even though the data collection and analysis were fairly complex.

\section{Limitations of Method}

The multiple-regression equations developed in this report for estimating flood magnitude and frequency are applicable to sites on small urban streams in South Carolina whose basin characteristics are within the range of the study sites used in the regression analysis. Prediction errors may be considerably greater than those suggested by the standard error of prediction, when the relations are applied to sites on streams having basin characteristics outside of the range of study site data, which is shown below.

\begin{tabular}{|c|c|c|c|}
\hline $\begin{array}{l}\text { Basin } \\
\text { charac- } \\
\text { teristic }\end{array}$ & Minimum & Maximum & Units \\
\hline$\underset{\text { TIA }}{\mathbf{A}}$ & $\begin{array}{l}0.18 \\
10.0\end{array}$ & $\begin{array}{l}41.0 \\
51.0\end{array}$ & $\begin{array}{l}\text { square miles } \\
\text { percent }\end{array}$ \\
\hline
\end{tabular}


Therefore, the equations should not be extrapolated to estimate peak discharges for basins with TIA values less than 10 percent or greater than 50 percent. The rural flood-frequency equations from Guimaraes and Bohman (1992) were derived using data from basins containing small amounts of impervious area (usually 1 - 5 percent). Thus, the rural equations from that report should be used when estimating peak discharges in that range of imperviousness.

The equations do not apply to urban streams where temporary in-channel storage or detention storage significantly affect the magnitude of peak flows. Detention storage, for this report, is defined as that storage occurring in planned areas, such as ponds upstream of dams, or unplanned detention areas, such as upstream of highway and railroad embankments. The peak outflow rate from these detention areas is usually less than the peak inflow rate because of the effects of storage. This differs from the more permanent storage in lakes, reservoirs, swamps, and wetlands depicted on topographic maps. The study sites chosen probably reflect average storage conditions and negligible permanent storage.

The equations also do not apply to non-homogeneous basins that have large subareas that differ greatly in urbanization or are rural. In such cases, the computed urban peak discharge may not closely represent the complex responses associated with the basin of interest. For example, if the lower part of a basin is urbanized and the upper part is either rural or less developed, rapid removal of floodflows from the lower part may occur before the upper part can contribute significant runoff.

In all cases, if the computed rural discharge exceeds the computed urban discharge, hydrologic judgment should be used in selecting the appropriate discharge.

\section{Computation of Peak Discharge}

The following procedure should be used for estimating peak discharges for small urban streams in South Carolina.

1. Determine the values of $A$, $T I A$, and $R Q_{T}$ as described in the section on "Computation of Basin Characteristics." $R_{\mathrm{T}}$ can be estimated from the equations listed in Supplement A (Guimaraes and Bohman, 1992).

2. Check the values obtained from step 1 to be sure they are within the range of data described in the section on "Limitations."

3. Select the appropriate equation from table 9 for the desired recurrence interval.

4. Substitute the values of $A$, $T I A$, and $R_{T}$ into the equation.

5. Compute the peak discharge. 


\section{Example Application}

Estimate the peak discharge for the 100-year flood for Sunnyside Canal at Orangeburg, South Carolina, located in the upper Coastal Plain.

1. The following basin characteristics are determined:

A $=1.07$ square miles

TIA $=37.0$ percent

$\mathbf{R Q}_{\mathrm{T}}$, the equivalent rural discharge, is computed using equations in Supplement $A$ of this report.

$\mathbf{R Q}_{100}-116(1.07)^{0.69}=122$ cubic feet per second

2. The basin characteristics are checked for adherence to the criteria described in "Limitations of the Method."

3. The appropriate equation to be applied from table 9 is:

$$
\mathrm{UQ}_{100}=10.4(\mathrm{~A})^{0.506}(\text { TIA })^{0.932}\left(\mathbf{R Q}_{100}\right)^{0.280}
$$

4. Substitute the basin characteristics into the equation:

$\mathrm{UQ}_{100}=10.4(1.07)^{0.506}(37)^{0.932}(122)^{0.280}$

5. The estimated peak discharge is:

$$
\mathrm{UQ}_{100}=1,200 \mathrm{ft}^{3} / \mathrm{s} \text {. }
$$

\section{AVERAGE BASIN LAG TIME RELATIONS FOR UNGAGED URBAN BASINS}

An estimate of lag time is required in addition to peak discharge in order to apply the dimensionless hydrograph techniques discussed later in this report. Therefore, the average station lagtimes obtained from the stations used in the dimensionless hydrograph development were related to their basin characteristics using multiple regression analyses. The average basin lag times for the 30 sites in South Carolina and Georgia and selected basin characteristics used in the lag time regression analysis are presented in table 8 .

Several combinations of L, S, TIA, A, BDF, RI2, and qualitative variables denoting physiographic province were used in the regression analyses. Many investigators have related lag time to basin length, $L$, and main channel slope, $\mathbf{S}$, with the explanatory variable taking the form $\mathrm{L} / \mathrm{S}^{0 \cdot 5}$. This variable, along with RI2 and TIA, were the three most significant variables in the regression analyses. All explanatory variables were significant at the 1 percent level except for RI2, which was significant at the 6 percent level. The inclusion of RI2 did not affect the results for the upper Coastal Plain and Piedmont sites, but did improve the lower Coastal Plain prediction estimates. The combination of the variables of $A$, $S$, and TIA produced comparable results for the Piedmont and upper Coastal Plain, but not for the lower Coastal Plain, where the RI2, TIA, and L/S $\mathbf{S}^{0 \cdot 5}$ variable grouping resulted in better prediction estimates. The final lag 
time equation shown below had a standard error of regression of \pm 22.3 percent, a standard error of prediction of \pm 23.8 percent, and a coefficient of determination of 0.89 .

$$
\mathbf{L T}=20.2\left(\mathrm{~L} / \mathrm{s}^{0.5}\right)^{0.623}(\mathrm{TIA})^{-0.919}(\mathrm{RI} 2)^{1.129}
$$

where LT is the average basin lag time, in hours;

$L$ is the main channel length, in miles;

$S$ is the main channel slope, in feet per mile;

TIA is the total impervious area, in percent; and

RI2 is the 2-year 2-hour rainfall amount, in inches.

\section{Sensitivity Analysis}

A graphical sensitivity analysis was made to illustrate the effects of measurement or judgment errors in determining the explanatory variables $\left(\mathrm{L} / \mathrm{S}^{0} .^{\mathrm{S}}, \mathrm{TIA}\right.$, and RI2) for estimating lag time. The means of the three explanatory variables, $\mathbf{L} / \mathbf{S}^{0} .^{5}$, TIA, and RI2, were calculated to be: 0.292 , 28.12 percent, and 2.19 inches, respectively. These values were substituted into the regression equation and each explanatory variable was varied by 5 percent increments from -50 to +50 percent, while holding the other variables constant. The percentage change in each explanatory variable and the percentage of change in the computed lag time is shown in figure 13 .

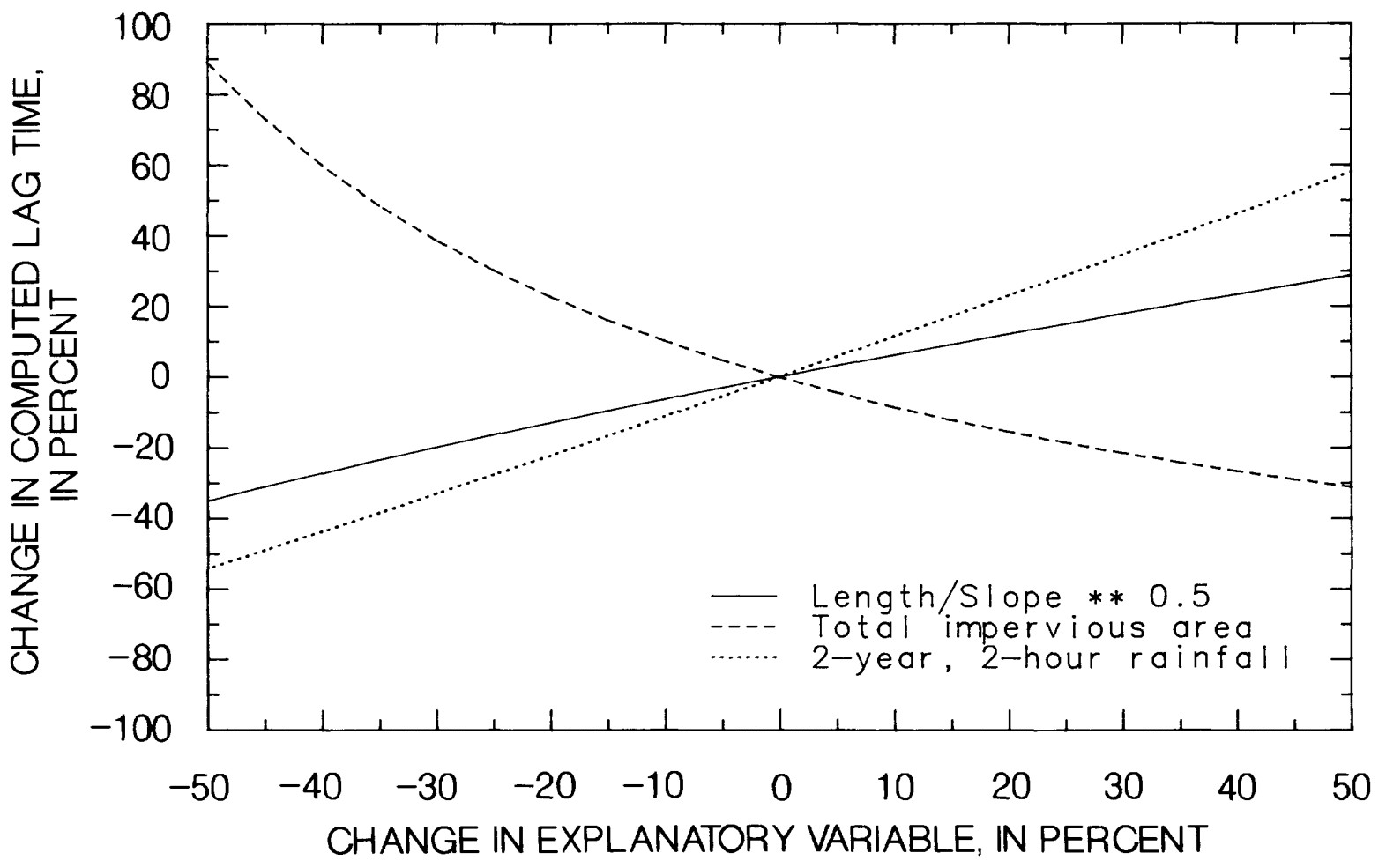

Figure 13.--Sensitivity of computed lag time to changes in the three explanatory variables for the average basin lag time equation. 


\section{Tests for Multicollinearity and Bias}

The explanatory variables were analyzed for possible multicollinearity as previously described. The predictive ability of the equation is not appreciably affected by multicollinearity. Bias tests indicated no significant parametrical or geographical bias in the regression equation developed in this study for average basin lag time.

\section{Application of Average Basin Lag Time Equations}

The average basin lag time equation developed in this study provides an estimating method for lag times for similar sites on ungaged urban streams in South Carolina. The result is not intended for direct use in hydrograph estimation using the dimensionless hydrograph because an adjustment factor, $F$, must be computed and used with the average basin lag times prior to using the dimensionless hydrographs. The equation may be used to estimate the lag time parameter used in the regression equations for runoff volume presented later in this report.

\section{Limitations of Method}

The multiple regression equation for estimating average basin lag time is applicable to sites on small urban streams (less than $10 \mathrm{mi}^{2}$ ) in South Carolina where basin characteristics are within the range of the study sites. Basins should be reasonably homogeneous with no large subareas differing greatly in the level of urbanization. Prediction errors may be considerably greater than those suggested by the standard error of prediction when the relations are applied to sites on streams having basin characteristics outside of the range of study site data listed below (North Carolina sites were not included in lag time regression analysis).

\begin{tabular}{|c|c|c|c|}
\hline teristic & Minimum & Maximum & Units \\
\hline $\begin{array}{l}\text { L/S } 0.5 \\
\text { TIA } \\
\text { RI2 }\end{array}$ & $\begin{array}{c}0.0493 \\
13.0 \\
1.95\end{array}$ & $\begin{array}{c}0.875 \\
51.0 \\
2.56\end{array}$ & $\begin{array}{l}\text { percent } \\
\text { inches }\end{array}$ \\
\hline
\end{tabular}

The following procedure should be used when calculating average basin lag time for ungaged urban streams in South Carolina.

1. Determine the values of $L, S$, TIA, and RI2 as described in the methods section on "Computation of Basin Characteristics."

2. Check the values obtained from step 1 to be sure they are within the range of data described in the previous section on "Limitations." 
3. Substitute the values of $L / \mathbf{s}^{0.5}$, TIA, and RI2 into equation 5 .

4. Compute the average basin lag time.

\section{Example Application}

Estimate the average basin lag time for Sunnyside Canal at Orangeburg, S.C., located in the upper Coastal Plain.

1. The following basin characteristics are determined:

L $=1.44$ miles

S $=67.4$ feet per mile

TIA $=37.0$ percent

RI2 $=2.20$ inches

2. These basin characteristics are checked for adherence to the criteria described in "Limitations of the Method."

3. The South Carolina urban lag time equation is (eq. 5):

$$
\text { LT }=20.2\left(\mathrm{~L} / \mathrm{s}^{0.5}\right)^{0.623}(\text { TIA })^{-0.919}(\text { RI2 })^{1.129}
$$

4. Substitute the basin characteristics into the equations:

$$
\text { LT }=20.2\left(1.44 / 67.4^{0.5}\right)^{0.623}(37)^{-0.919}(2.20)^{1.129}
$$

5. The estimated lag time is 0.60 hours.

\section{RUNOFF VOLUME RELATIONS FOR UNGAGED URBAN BASINS}

Floodwater detention storage is an important consideration in the economic design of some hydraulic structures. In such cases, the volume of runoff associated with a design flood must be estimated. Multiple regression analyses of volumes and certain basin characteristics were made using data from 139 events at 30 gaging stations in South Carolina and Georgia having concurrent rainfall and discharge data. Two equations were developed with drainage area (A), observed peak discharge $\left(Q_{p}\right)$, and average basin lag time (LT) as significant explanatory variables.

The three explanatory variables ( $A, Q$, and $L T$ ) were significant at the 1 percent level. A qualitative variable, hsed to define the difference in volume relations between the lower Coastal Plain and other areas in the State, was only significant at the 7 percent level, but was included because it improved predicted volumes for the lower Coastal Plain. The urban runoff volume relations have a standard error of regression of \pm 18.4 percent, a standard error of prediction of \pm 18.7 percent, and a coefficient of determination of 0.88 . Equations 6 and 7 below should be used to estimate the average runoff volumes associated with a peak discharge for the Piedmont-upper Coastal Plain and lower Coastal Plain, respectively. 
Piedmont-upper Coastal Plain

$$
\begin{aligned}
\mathbf{V}_{\mathbf{R}} & =0.001525(\mathrm{~A})^{-1.038}\left(\mathbf{Q}_{\mathbf{P}}\right)^{1.013}(\text { LT })^{1.030} \\
\text { Lower Coastal P1ain } & \mathbf{V}_{\mathbf{R}}=0.001648(\mathrm{~A})^{-1.038}\left(\mathbf{Q}_{\mathbf{P}}\right)^{1.013}(\text { LT })^{1.030}
\end{aligned}
$$

where $V_{R}$ is the average runoff volume, in inches;

$A^{R}$ is the drainage area, in square miles;

$Q_{\text {}}$ is the peak discharge, in cubic feet per second; and

LP is the average basin lag time, in hours.

Simple average basin lag time, computed using equation 5, should be used in the volume equations and should not be confused with the adjusted lag times $\left(\mathbf{L T}_{\mathbf{A}}\right)$ that are used with the dimensionless hydrograph only.

\section{Sensitivity Analysis}

As with the peak discharge and lag-time equations, sensitivity of the estimated runoff volume to the effects of measurement or judgment errors in determining $A, Q$, and $L T$ were shown graphically. The means of the three explanatory varigbles, $A, Q$, and $L T$, were calculated to be: $1.99,270$, and 1.16, respectively. These falues were substituted into the regression equation and each explanatory variable was varied by 5 -percent increments from -50 to +50 percent, while holding the other variables constant. The percentage change in each explanatory variable and the percentage of change in the computed runoff volume are shown in figure 14.

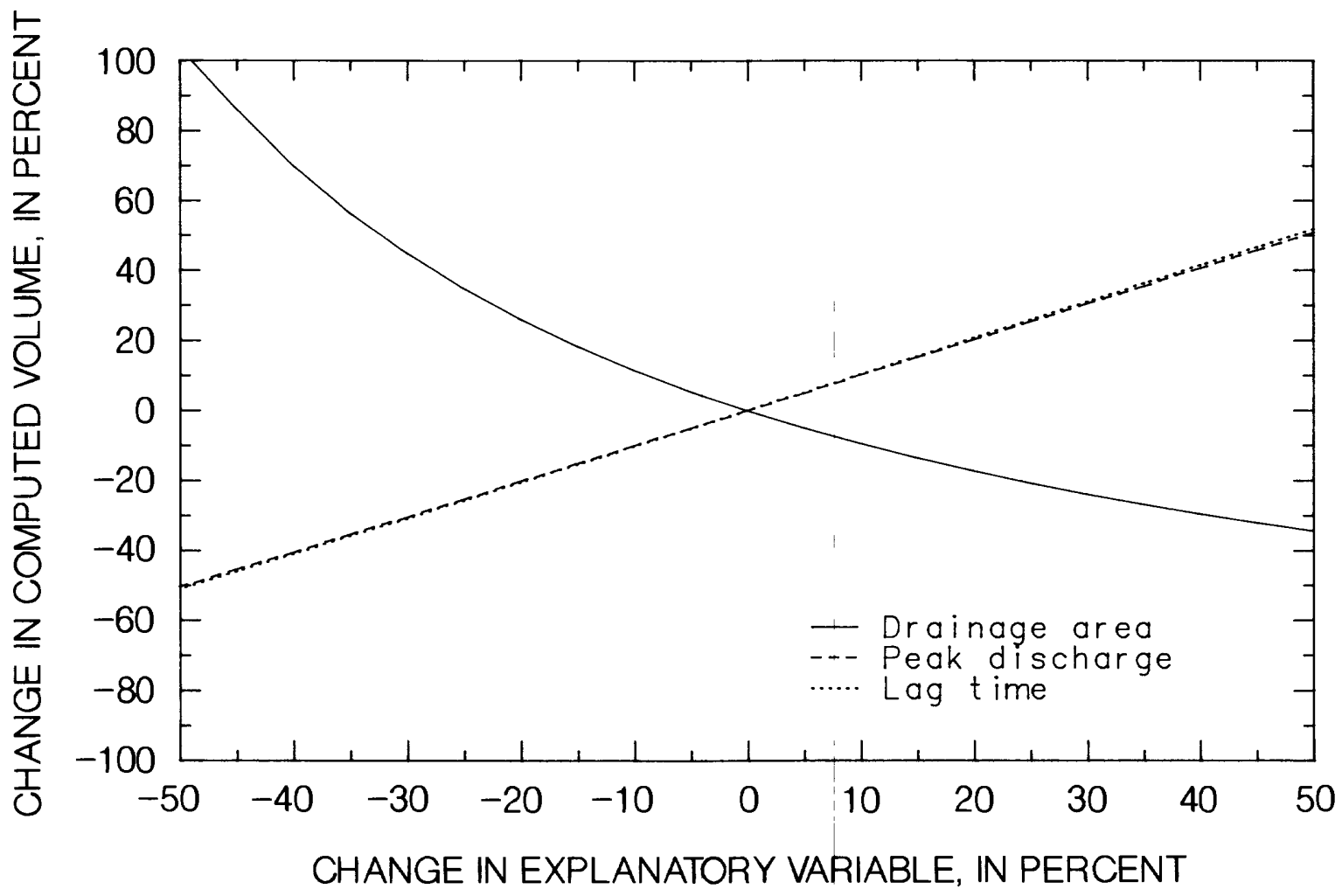

Figure 14.--Sensitivity of computed runoff volume to changes in the three explanatory variables for the runoff volume equations. 


\section{Tests for Multicollinearity and Bias}

A statistical analysis of the explanatory variables showed that the runoff volume equations were not affected by multicollinearity. An average of the residuals in percent of the 3 to 5 events at each site was plotted on a state map to screen for geographic bias. No regional trends were noted, but the results varied greatly from city to city. Plots of residuals for each of the 139 events and the explanatory variable values associated with each observation were made as previously described to test for variable bias. The scatter of plotting points appeared to be random; therefore, the form of the estimating equations is assumed to be unbiased.

\section{Application of Runoff Volume Equations}

The runoff volumes estimated using equations 6 and 7 represent only the average volumes that would occur as the result of a single-peaked hydrograph having a peak discharge of specific recurrence interval. It is important to realize that any given flood event cannot be assumed to have both a peak discharge and a runoff volume of the same recurrence interval. Sauer (1964) found that a wide variation may exist between the recurrence intervals computed for storm runoff and corresponding peak discharge. This variation was explained by several factors that affect the relation between storm runoff and peak discharge. Sauer explained that two storms having identical total runoff may have different peaks because of different storm durations or a different distribution of rainfall over the basin. Other factors that may cause variations in the peak discharge-storm runoff relation are direction of storm movement and the flow in the channel at the time of storm runoff, which may include only base flow or base flow plus flow from the recession of a previous storm.

Therefore, although peak discharge may be highly related to runoff volume (Bohman, 1990, Rogers and Zia, 1982, and Singh and Aminian, 1986), their frequency relation is a complex one. Just as there are many possible volumes that can be associated with a peak discharge of specific recurrence interval, there are likewise many possible peak discharges for a runoff volume of given recurrence interval. A study to regionalize volumefrequency relations was not made in South Carolina because of time and financial constraints. J.M. Sherwood (U.S. Geological Survey, written commun., 1990) investigated volume-duration-frequency relations for urban streams in Ohio. In that study, the largest runoff volume for each of six durations ( $1,2,4,8,16$, and 32 hours) was computed for each water year of synthetic hydrograph data. The logarithms of the annual peak volumes for each duration were fit by a Pearson Type III frequency distribution to develop a volume-duration-frequency relation for each site. The results were used in multiple-regression analyses to regionalize the relations for estimating maximum flood volumes of various durations and recurrence intervals. The results were compared to the dimensionless hydrograph volume estimates. Both methods yielded similar results for short-duration events, but, for longer events, the volume-duration-frequency equations generally resulted in larger volumes. 
The dimensionless hydrograph or regression model volumes in this report should not be assumed to have the same recurrence interval as the peak discharge. The relations for hydrograph shapes, widths, and volumes defined in this report should be considered to be averages associated with a peak discharge of specific recurrence interval. Any differences between actual hydrographs or volumes and those simulated by using the techniques presented herein, simply represent the variation of actual hydrographs from the average or typical hydrographs for the given peak discharge. Proper application of the volume equations is described below.

\section{Limitations of Method}

Due to the short data collection period necessary for this study, few large, single-peaked events were available. The equations for estimating urban runoff volume are applicable only for small basins (less than $10 \mathrm{mi}^{2}$ ) in South Carolina with basin characteristics and peak discharges within the range of those used in the regression analysis. As with the previously discussed regression equations for peak discharge and lag time, the volume equations are not applicable in basins with large rural sub-basins or areas with extreme contrasts in level of urbanization.

Previous studies by Bohman (1990) and Inman (1986) demonstrated the applicability of the volume estimations using the largest peaks of record (average recurrence interval was about 30 years) at several gaging stations on rural streams in South Carolina and Georgia. Therefore, use of the equations to predict average volumes associated with events having much larger recurrence intervals than those used in the study is assumed to be acceptable. The range of data used in the volume regression analyses is listed below (North Carolina data were not used in volume regression analysis).

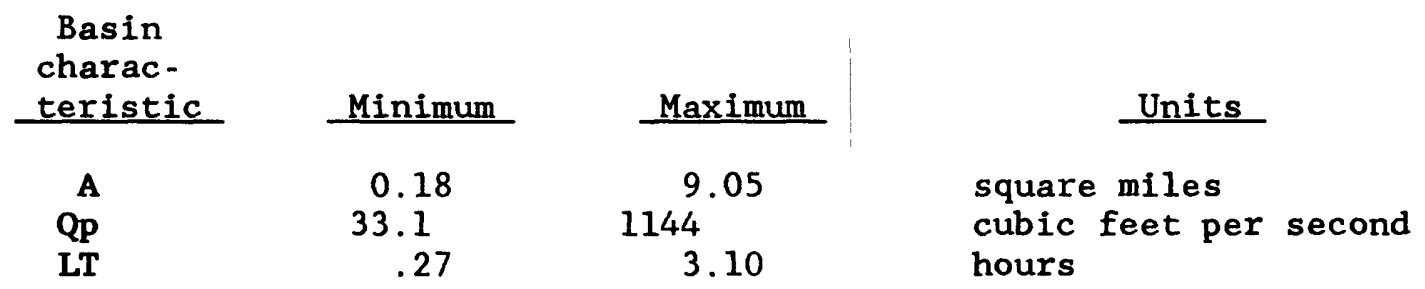

Computation of Runoff Volume

The following procedure should be used to estimate runoff volumes for small urban streams in South Carolina.

1. Determine the value of $A$ as described in the section on "Computation of Basin Characteristics." The value for $Q$ can be any desired value for an urban stream or may be computed using the equations in table 9 in this report. An estimate of LT may likewise be estimated using equation 5 . 
2. Check the values for $A$ and LT to be sure they are within the range of data described in the section on "Limitations."

3. Select the appropriate equation (eq. 6 or 7) that corresponds to the physiographic region in which the basin of interest is located.

4. Substitute the values of $\mathbf{A}, \mathbf{Q}_{\mathbf{p}}$, and $\mathbf{L} T$ into the equation.

5. Compute the runoff volume.

\section{Example Application}

Estimate the average runoff volume for the 100-year flood for Sunnyside Canal at Orangeburg, South Carolina, located in the upper Coastal Plain.

1. The following basin/event characteristics are determined:

A - 1.07 square miles

$Q_{p}=1,200$ cubic feet per second (UQ ${ }_{100}$ from table 9 , calculated as shown in the Example Application for peak discharge)

LT $=0.60$ hours (from equation 5 , calculated as shown in the Example Application for lag time)

2. The basin characteristics are checked for adherence to the criteria described in "Limitations of the Method."

3. The appropriate equation for the upper Coastal Plain is:

$$
v=0.001525(A)^{-1.038}\left(Q_{p}\right)^{1.013}(\text { LT })^{1.030}
$$

4. Substitute the basin/event characteristics into the equations:

$$
v=0.001525(1.07)^{-1.038}(1,200)^{1.013}(0.60)^{1.030}
$$

5. The estimated runoff volume is 1.11 inches.

\section{ESTIMATION OF FLOOD HYDROGRAPHS FOR UNGAGED URBAN BASINS}

Estimated flood hydrographs may be used to evaluate the effects of storage upstream of an existing riverine structure on peak discharge, or for design purposes, for example, to select a culvert size in order to take advantage of available embankment storage in reducing peak discharges downstream.

Data from 139 events in 14 cities in South Carolina and Georgia were used in this investigation to develop dimensionless hydrographs for use in estimating urban flood hydrographs. The method requires only two parameters, the design peak discharge and basin lag time (adjusted for correct runoff volume), to compute the design hydrograph. The result is a typical or average hydrograph associated with the peak discharge of known recurrence interval. 


\section{Dimensionless Hydrographs for South Carolina}

The dimensionless hydrograph is developed by averaging typical single-peak hydrographs of average duration from a variety of basins. Studies by Robbins (1986), Olin and Atkins (1988), Neely (1989), and Sherwood (1986) have all verified a dimensionless hydrograph developed by Inman (1986) for use on both rural and urban stream sites. The Inman dimensionless hydrograph was used to simulate the events used in this study to test its applicability. The standard error of hydrograph widths at 50 and 75 percent of peak stormflow was \pm 26.3 and \pm 30.0 percent, respectively. Although the overall results using Inman's dimensionless hydrograph seem acceptable, the hydrograph widths at 75 percent of peak flow for events in the Piedmont and upper Coastal Plain were overestimated by an average of 10 percent.

Several average dimensionless hydrographs, derived from various combinations of individual station dimensionless hydrographs, were tested to determine which regional hydrograph best fits the observed data. The groupings were:

1. Piedmont physiographic province data.

2. Upper Coastal Plain physiographic data.

3. Lower Coastal Plain physiographic data.

4. Data from all 3 physiographic provinces.

5. Upper and lower Coastal Plain physiographic province data.

6. Piedmont and upper Coastal Plain physiographic province data.

A dimensionless hydrograph developed from the three-province data base (grouping number 4) did not provide accurate and unbiased results. The estimated hydrograph widths were overpredicted in the Piedmont and underpredicted in the lower Coastal Plain.

The average dimensionless hydrograph with the lag time duration that gave the best results for the first three groupings listed above was plotted for comparison in figure 15. The plot indicates that the Piedmont and upper Coastal Plain stations have hydrographs similar in width but the lower Coastal Plain hydrograph is substantially wider. The dimensionless widths are listed below at 50 and 75 percent of peak flow for further comparison:

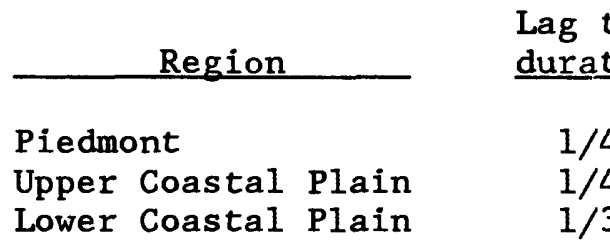

\section{Dimensionless Hydrograph Widths

$0.50 \mathrm{Qp} \quad 0.75 \mathrm{Qp}$

$$
\begin{array}{r}
0.820 \text { units } \\
.842 \text { units } \\
.945 \text { units }
\end{array}
$$

0.475 units

.503 units

.552 units 
Based on figure 15 and the standard error of width comparisons made for the many groupings listed, two dimensionless hydrographs were selected for use in South Carolina. The dimensionless hydrograph developed using Piedmont and upper Coastal Plain stations with a one-fourth lag time duration was chosen for use in those regions. The standard error of estimate of hydrograph widths at 50 and 75 percent of peak flow was \pm 26.7 and \pm 29.9 percent, respectively. The dimensionless hydrograph derived for use in the lower Coastal Plain had a duration equal to one-third lag time and standard errors of \pm 20.6 and \pm 25.4 percent for estimated hydrograph widths at 50 and 75 percent of peak flow, respectively. The coordinates of both dimensionless hydrographs are listed in table 10 and are shown graphically in figures 16 and 17.

\section{Adjusting Average Basin Lag Time for Correct Runoff Volume}

As explained in the "Methods of Analysis" section, the volume associated with the dimensionless hydrograph can be numerically defined as shown in equation 4 . The volume conversion constant $K$ in equation 4 was determined for the two hydrographs selected in this study for use in estimating urban flood hydrographs:

$$
\begin{aligned}
& \mathbf{K}_{\text {Piedmont-upper Coastal Plain }}=0.001577 \\
& \mathbf{K}_{\text {lower Coastal Plain }}=0.001765
\end{aligned}
$$

When these values are substituted into equation 4 it can be seen that the dimensionless hydrograph volume constants and coefficient values in equations 8 and 9 are very close to those determined by regression analyses (equations 6 and 7).

Piedmont-upper Coastal Plain dimensionless hydrograph:

$$
\mathrm{v}_{\mathrm{D}}=0.001577(\mathrm{~A})^{-1.0}\left(\mathrm{Q}_{\mathrm{P}}\right)^{1.0}(\mathrm{LT})^{1.0}
$$

Lower Coastal Plain dimensionless hydrograph:

$$
\mathbf{V}_{D}=0.001765(A)^{-1.0}\left(Q_{\mathbf{P}}\right)^{1.0}(\text { LT })^{1.0}
$$




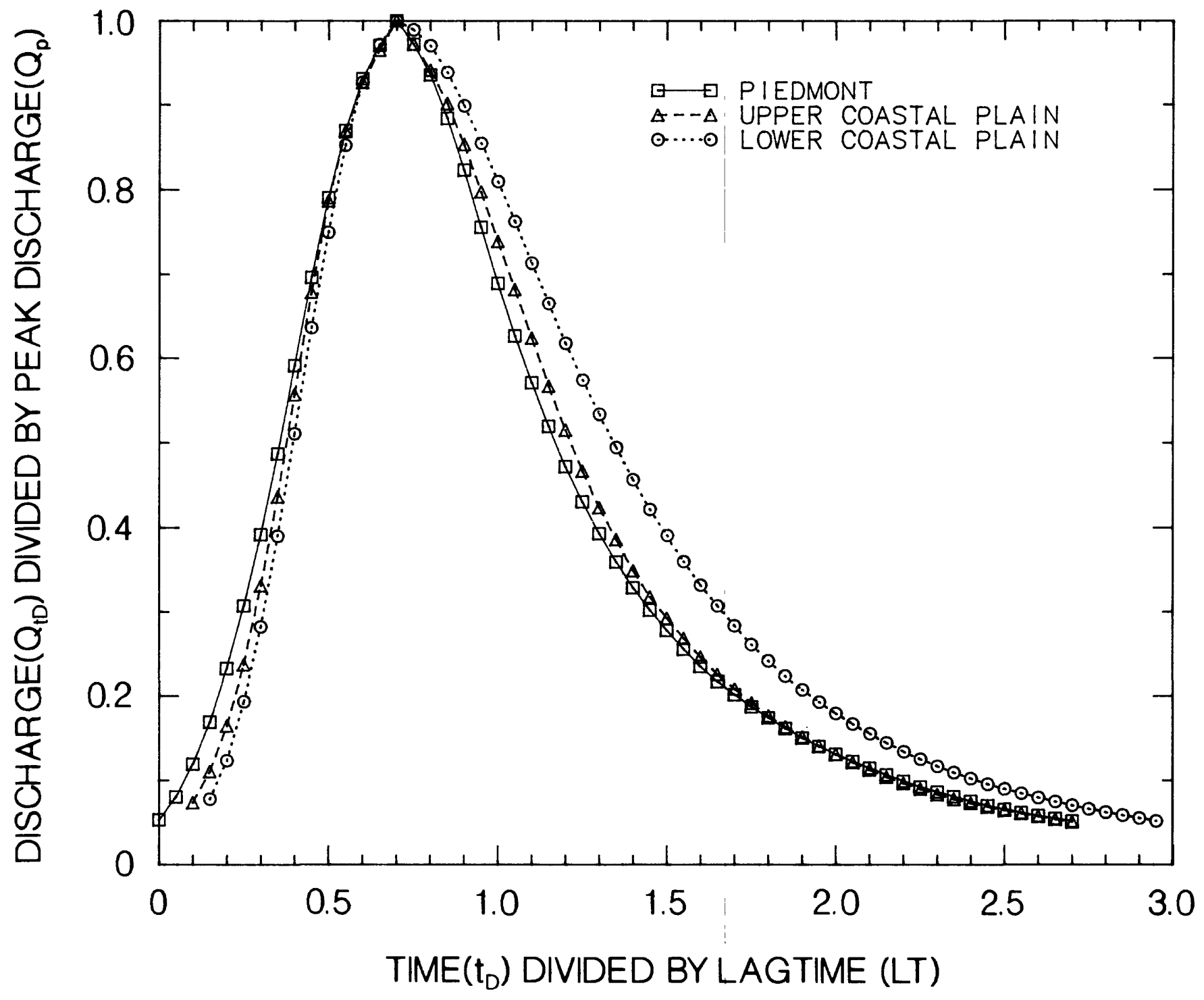

Figure 15.--Average dimensionless hydrographs for the Piedmont, upper Coastal Plain, and lower Coastal Plain with peaks aligned. 
Table 10.- Time and discharge ratios of the urban dimensionless hydrographs for the Piedmont-upper Coastal Plain and lower Coastal Plain regions

[ $t_{D}$, time in hours; LT, lag time, in hours; $Q_{t D}$, discharge at time $t$, in cubic feet per second; $Q_{p}$, peak discharge, in cubic feet per second; -... , indicate no data]

Time ratio

$\left(t_{D} / L T\right)$
Discharge ratio

$\left(Q_{t D} / Q_{p}\right)$

$\begin{array}{lc}\text { Piedmont-upper } & \text { Lower Coastal } \\ \text { Coastal Plain } & \text { Plain }\end{array}$

$\begin{array}{rrr}0 & 0.07 & -. . \\ .10 & .10 & 0.08 \\ .15 & .15 & .12 \\ .20 & .21 & .19 \\ .25 & .28 & .28 \\ .30 & .37 & .39 \\ .35 & .47 & .51 \\ .40 & .58 & .64 \\ .45 & .69 & .75 \\ .50 & .79 & .85 \\ .55 & & .93 \\ .60 & .87 & .97 \\ .65 & .93 & 1.00 \\ .70 & .97 & .99 \\ .75 & 1.00 & .97 \\ .80 & .97 & .94 \\ .85 & & .90 \\ .90 & .94 & .86 \\ .95 & .89 & .81 \\ 1.00 & .83 & .76 \\ 1.05 & .77 & .71 \\ 1.10 & .71 & .66 \\ 1.15 & & .62 \\ 1.20 & .65 & .57 \\ 1.25 & .59 & .53\end{array}$


Table 10.- Time and discharge ratios of the urban dimensionless hydrographs for the Piedmont-upper Coastal Plain and lower Coastal Plain regions - Continued

[ $t_{D}$, time in hours; LT, lag time, in hours; $Q_{t D}$, discharge at time $t$, in cubic feet per second; $Q_{p}$, peak discharge, in cubic feet per second; ...... indicate no data]

Time ratio

$\left(t_{D} / L T\right)$
Discharge ratio

\begin{tabular}{lc}
\multicolumn{2}{c}{\begin{tabular}{c}
$\left(Q_{t D} / Q_{p}\right)$ \\
\hline Piedmont-upper
\end{tabular}} \\
Coastal Plain & Plain
\end{tabular}

1.30

1.35

1.40

1.45

1.50

1.55

1.60

1.65

1.70

1.75

1.80

1.85

1.90

1.95

2.00

2.05

2. 10

2.15

2. 20

2.25

2.30

2.35

2.40

2.45

2.50
0.40

.37

.34

.31

.28

0.26

.24

.22

.20

.19

.17

.16

.15

.14

.13

.12

.11

.11

.10

.09

.09

.08

.07

.07

.06
.49

.46

.42

.39

.36

0.33

.31

.28

.26

.24

.22

.21

.19

.18

.17

.16

.14

.13

.13

.12

.11

.10

.10

.09

.08 


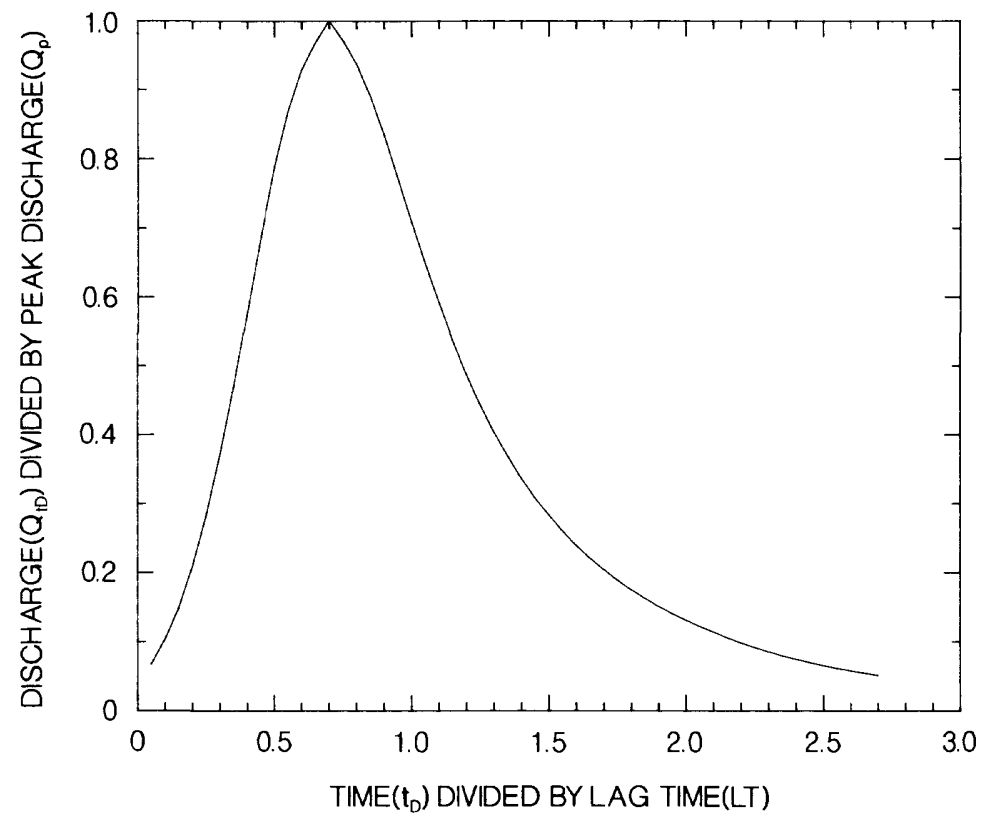

Figure 16.--Dimensionless hydrograph for use in estimating hydrographs in the Piedmont and upper Coastal Plain physiographic provinces.

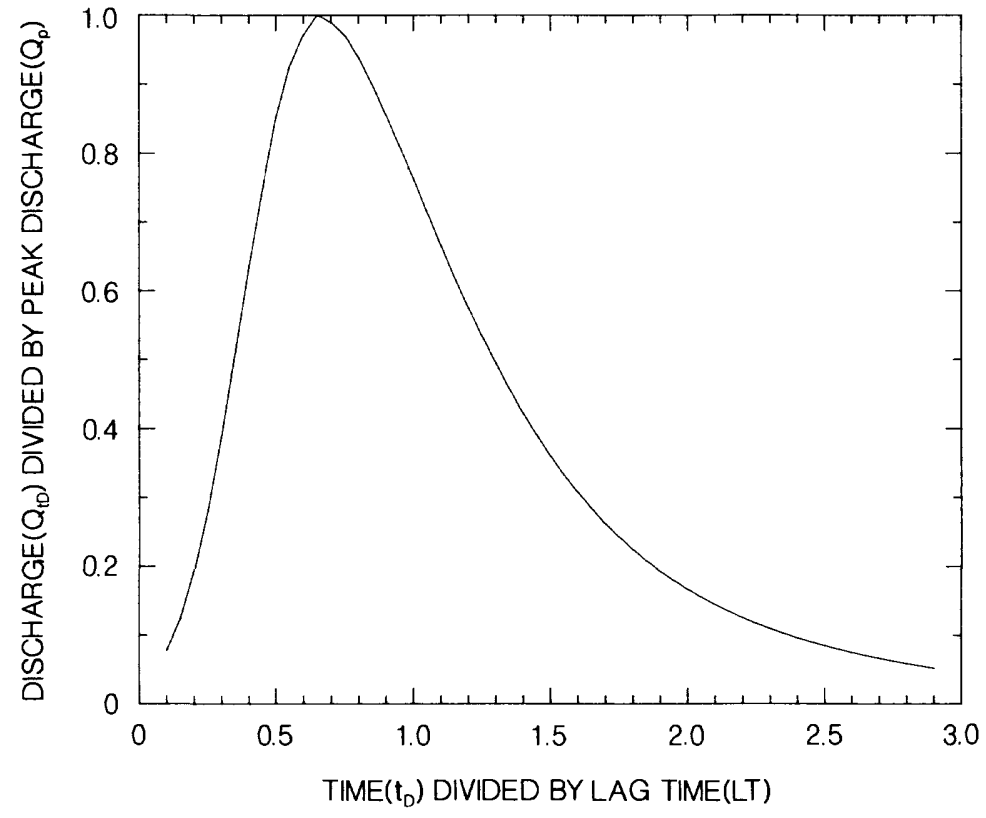

Figure 17.--Dimensionless hydrograph for use in estimating hydrographs in the lower Coastal Plain physiographic province. 
The actual differences between estimates using the dimensionless hydrograph volume relations (equations 8 and 9 ) and the regression volume relations (equations 6 and 7 ) is also fairly small, indicating results from either method would be comparable in most situations. Analyses of variance and covariance did not indicate any statistically significant differences between the two methods. However, a plot of the ratio of regression volumes to dimensionless hydrograph volumes and each of the three explanatory variables ( $A, \mathbf{Q}_{\mathbf{p}}$, and $\mathbf{L T}$ ) showed a trend with the drainage area and peak discharge.

Therefore, a lag-time correction factor (F), computed as the ratio of regression to dimensionless hydrograph volume, was used to adjust for these trends. Equations 6 through 9 were reduced to the two equations for $F$ listed below that are applicable in the indicated regions:

$$
\begin{aligned}
& F_{\text {Piedmont-upper Coastal Plain }}=0.967(\mathbf{A})^{-0.038}\left(\mathbf{Q}_{\mathbf{P}}\right)^{0.013}(\mathbf{L T})^{0.030} \\
& \mathbf{F}_{\text {lower Coastal Plain }}=0.934(\mathbf{A})^{-0.038}\left(\mathbf{Q}_{\mathbf{P}}\right)^{0.013}(\mathrm{LT})^{0.030}
\end{aligned}
$$

An adjusted basin lag time ( $L T_{A}$ ) required for simulating flood hydrographs can be computed as follows:

(1) Compute the average basin lag time (LT) from equation 5.

(2) Compute the lag time correction factor (F) from the appropriate equation (eq. 10 or 11) above.

(3) Multiply the results of steps (1) and (2) to obtain the adjusted lag time.

The average basin lag times for each of the 139 events used to develop the two dimensionless hydrographs for South Carolina were corrected by the appropriate $\mathbf{F}$ factor and the standard errors for widths were recomputed. Almost no improvement was noted in the Piedmont-upper Coastal Plain hydrograph width errors, and only about a 1 percent improvement was made in the lower Coastal Plain hydrographs. The adjusted standard error of estimates for hydrograph widths at 50 and 75 percent of peak flow, respectively, was \pm 27.0 and \pm 29.8 percent for Piedmont-upper Coastal Plain hydrographs and \pm 19.8 and \pm 24.5 percent for lower Coastal Plain hydrographs.

\section{Hydrograph-Width Relations}

Some hydraulic analyses require only an estimate of the period of time during which a specific discharge will be exceeded for a given flood. In these cases a complete hydrograph is not needed and the hydrograph widths can be determined from the hydrograph-width relations, shown graphically in figure 18 and tabulated in table 11. The hydrograph-width ratios were determined by subtracting the value of $t / L T$ on the rising limb of the dimensionless hydrographs from the value of t/LT on the falling limb of the hydrograph at the same discharge ratio $\left(Q_{t D} / Q p\right)$ over the full range of each dimensionless hydrograph. The simulated hydrograph width (W) in hours can 
be estimated for a desired discharge (Qp) by first computing the ratio $Q_{\text {to }} / Q p$ and then multiplying the corresponding W/LT ratio in table 11 by the estimated basin lag time that has been corrected for volume (LT $)$. The resulting hydrograph width is the period of time a particular discharge will be exceeded.

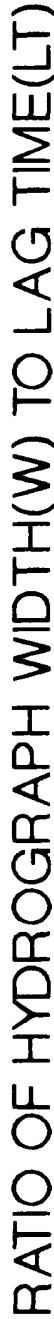

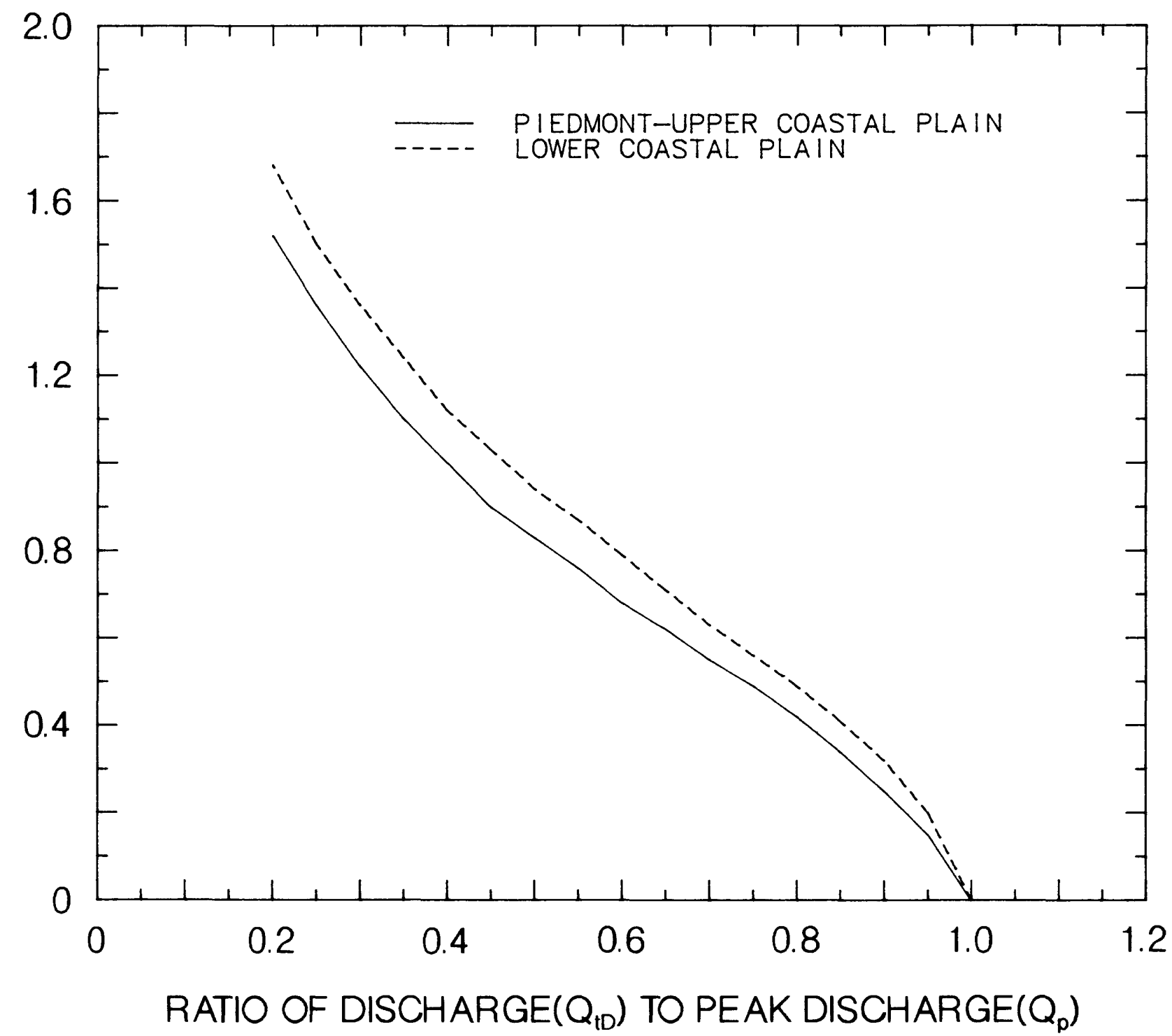

Figure 18.--Hydrograph for the indicated dimensionless hydrographs. 
Table 11.--Relation of discharge ratios to hydrograph width ratios for the Piedmont-upper Coastal Plain and lower Coastal Plain regions

[Q $\mathbf{Q}_{\mathrm{t}}$, discharge, in cubic feet per second; Qp, peak discharge, in cubic feet per second; $W$, hydrograph width, in hours; LT, lag time, in hours.]

\begin{tabular}{|c|c|c|}
\hline \multirow[t]{2}{*}{$\begin{array}{c}\text { Discharge ratio } \\
\left(\mathbf{Q}_{\mathrm{tD}} / \mathbf{Q p}\right)\end{array}$} & \multicolumn{2}{|c|}{$\begin{array}{l}\text { Width ratio } \\
\text { (W/LT) }\end{array}$} \\
\hline & $\begin{array}{l}\text { Piedmont-upper } \\
\text { Coastal Plain }\end{array}$ & $\begin{array}{c}\text { Lower Coastal } \\
\text { Plain }\end{array}$ \\
\hline $\begin{array}{r}1.00 \\
.95 \\
.90 \\
.85 \\
.80\end{array}$ & $\begin{array}{r}0.00 \\
.15 \\
.25 \\
.34 \\
.42\end{array}$ & $\begin{array}{r}0.00 \\
.20 \\
.32 \\
.41 \\
.49\end{array}$ \\
\hline $\begin{array}{l}.75 \\
.70 \\
.65 \\
.60 \\
.55\end{array}$ & $\begin{array}{l}.49 \\
.55 \\
.62 \\
.68 \\
.76\end{array}$ & $\begin{array}{l}.56 \\
.63 \\
.71 \\
.79 \\
.87\end{array}$ \\
\hline $\begin{array}{l}.50 \\
.45 \\
.40 \\
.35 \\
.30\end{array}$ & $\begin{array}{r}.83 \\
.90 \\
1.00 \\
1.10 \\
1.22\end{array}$ & $\begin{array}{r}.94 \\
1.03 \\
1.12 \\
1.24 \\
1.36\end{array}$ \\
\hline $\begin{array}{l}.25 \\
.20\end{array}$ & $\begin{array}{l}1.36 \\
1.52\end{array}$ & $\begin{array}{l}1.50 \\
1.68\end{array}$ \\
\hline
\end{tabular}

Sensitivity Analysis

As with the regression analyses, the sensitivity of the simulated hydrograph widths to errors in the two independent variables (Qp and $\mathbf{L} \mathbf{T}_{\mathbf{A}}$ ) was investigated. Mathematically, when peak discharge is varied, hydrograph width does not change. When lag time is varied, hydrograph widths vary by an equal percentage. 


\section{Application of the Dimensionless Hydrograph Method}

The following sections describe the procedures for estimating flood hydrographs with a specified peak discharge at urban streams in South Carolina. Adjusted basin lag time ( $\mathbf{L T}_{\mathrm{A}}$ ) and peak discharge (Qp) are applied to one of two dimensionless hydrographs (Piedmont-upper Coastal Plain or lower Coastal Plain) to compute a typical (average) flood hydrograph for the given peak discharge. Because the dimensionless hydrographs were developed from events of average duration, the procedure will generate a hydrograph of average duration. Floods of similar peak discharge but considerably longer (or shorter) duration (or volume) also are likely to occur.

\section{Limitations of Method}

The method should be limited to ungaged sites that have basin characteristics similar to those of the 30 gaged sites used in the peak and lag time regression analyses. The table below gives the ranges of the explanatory variables used in the peak discharge and lag time regression analyses.

\begin{tabular}{|c|c|c|c|}
\hline $\begin{array}{l}\text { Basin } \\
\text { charac- } \\
\text { teristic } \\
\end{array}$ & Minimum & Maximum & Units \\
\hline \begin{tabular}{l}
\multicolumn{1}{c}{ A } \\
TIA \\
L/S ${ }^{0} \cdot \mathbf{5}$ \\
RI2
\end{tabular} & $\begin{array}{c}0.18 \\
10.0 \\
.0493 \\
1.95\end{array}$ & $\begin{array}{c}41.0 \\
51.0 \\
.875 \\
2.56\end{array}$ & $\begin{array}{l}\text { square miles } \\
\text { percent } \\
-- \\
\text { inches }\end{array}$ \\
\hline
\end{tabular}

Although the dimensionless hydrographs developed for use in South Carolina in this study were derived from data collected at basins where the land use or drainage system development was not always uniform, the technique is best suited for basins with homogeneous urbanization and no large rural areas.

The method should not be used to estimate a series of hydrographs over a whole basin to be routed to a downstream point. The sub-basin lag times are all shorter than the lag time of the total basin and the resultant flood hydrograph would be smaller than it should be for the whole basin.

The dimensionless hydrograph technique will not estimate flood hydrographs where double peaks can be expected to occur except for the special case where streams having the same size and basin characteristics join at the point of interest. Double peaks generally are the result of tributary flow entering the main channel just upstream of a stream site or from substantial changes in land use, soils, impervious cover, or drainage efficiency between upstream and downstream areas of the watershed. 
The dimensionless hydrograph is not intended for use in reproducing an actual storm hydrograph. It yields only an average flood hydrograph for a specified peak discharge. Hydrographs for basins with significant permanent storage such as ponds, lakes, and swamps should not be estimated using the dimensionless hydrograph technique.

\section{Computation of Flood Hydrographs}

The step-by-step method below may be used to estimate flood hydrographs with a specific peak discharge for small urban streams in South Carolina.

1. Estimate the peak discharge (Qp), using the equations in table 9 and the procedure described in "Computation of Peak Discharge" (Peak discharges determined by other methods may be used provided that the average hydrograph assumption is valid).

2. Estimate the basin lag time (LT) using the procedure described in "Computation of Average Basin Lag Time" using equation 5.

3. Compute the adjustment factor, F, for lag time using the appropriate regional equation (eq. 10 or 11 ).

4. Multiply the lag-time correction factor, $F$, obtained in step 3 by the $\mathbf{L T}$ computed in step 2 to obtain the adjusted lag time $\left(\mathbf{L T}_{\mathbf{A}}\right)$.

5. Multiply each value of $t / L T$ from the appropriate regional dimensionless hydrograph (table 10 ) by $\mathbf{L T}_{\mathrm{A}}$. These computed values are the time $(t)$ coordinates for the hydrograph: $t=\left(t_{D} / L T\right)\left(L_{A}\right)$.

6. Multiply each value of $Q_{t p} / Q p$ from the appropriate regional dimensionless hydrograph $($ table 10 ) by $Q$. These computed values are the corresponding discharge coordinates at time $t: Q_{t}=$ $\left(Q_{t D} / Q_{p}\right)\left(Q_{p}\right)$.

7. Plot time $(t)$ and discharge $\left(Q_{t}\right)$.

\section{Example Application}

Estimate the flood hydrograph corresponding to a 100-year peak discharge for Sunnyside Canal at Orangeburg, South Carolina, located in the upper Coastal Plain.

1. Determine the basin characteristics needed to estimate the 100-year peak discharge and average basin lag time.

$A=1.07$ square miles

TIA $=37.0$ percent

$\mathbf{R Q}_{\mathbf{T}}$, the equivalent rural discharge, is computed using equations in Supplement A of this report.

$\mathbf{R Q}_{100}=116(1.07)^{0.69}=122$ cubic feet per second 
L $=1.44$ miles

S $=67.4$ feet per mile

RI2 $=2.20$ inches

Physiographic region = upper Coastal Plain

2. The 100-year peak discharge is estimated using the appropriate equation from table 9.

$$
\begin{aligned}
\mathrm{UQ}_{100} & =10.4(\mathrm{~A})^{0.506}(\mathrm{TIA})^{0.932}\left(\mathrm{RQ}_{100}\right)^{0.280} \\
\mathrm{UQ}_{100} & =10.4(1.07)^{0.506}(37)^{0.932}(122)^{0.280} \\
\mathrm{UQ}_{100} & =1,200 \mathrm{ft}^{3} / \mathrm{s}
\end{aligned}
$$

3. Estimate the average basin lag time using equation 5 .

$$
\begin{aligned}
& \mathbf{L T}=20.2\left(\mathbf{L} / \mathbf{S}^{0.5}\right)^{0.623}(\text { TIA })^{-0.919}(\text { RI2) })^{1.129} \\
& \mathbf{L T}=20.2\left(1.44 / 67.4^{0.5}\right)^{0.623}(37.0)^{-0.919}(2.20)^{1.129} \\
& \mathbf{L T}=0.60 \text { hours }
\end{aligned}
$$

4. Determine the lag-time correction factor, $\mathbf{F}$, from equation 10 (Piedmont-upper Coastal Plain):

$$
\begin{aligned}
& \mathbf{F}=0.967(\mathbf{A})^{-0.038}\left(\mathbf{Q}_{\mathbf{P}}\right)^{0.013}(\mathbf{L T})^{0.030} \\
& \mathbf{F}=0.967(1.07)^{-0.038}(1200)^{0.013}(0.60)^{0.030} \\
& \mathbf{F}=1.04
\end{aligned}
$$

5. The correction factor from step 4 is multiplied by the estimated lag time from step 3 .

$\mathbf{L T}_{\mathrm{A}}=(0.60)(1.04)$

$\mathbf{L T}_{\mathrm{A}}=0.62$ hours

6. Each value of $t_{D} / \mathbf{L T}$ in table 10 is multiplied by 0.62 hours (results are presented in table 12).

7. Each value of $Q_{t D} / Q_{p}$ in table 10 is multiplied by 1,200 cubic feet per second (results are presented in table 12).

8. Time $(t)$ and discharge $\left(Q_{t}\right)$ are plotted as shown in figure 19. 
Table 12.- Example computation of estimated hydrograph for 100 year peak discharge for Sunnyside Canal at Orangeburg (sta. no. 02173495)

[ $t_{D}$, time, in hours; $t$, time in hours; LT, lag time, in hours; LT , lag time adjusted for correct runoff volume, in hours; $Q_{t D}$, discharge at $t A^{A}$ e $t$, in cubic feet per second; $Q_{t}$, discharge at time $t, y_{3}$ cubic feet per second; $Q_{p}$, peak discharge, in cubic feet per second; $\mathrm{ft}^{3} / \mathrm{s}$, cubic feet per second]

\begin{tabular}{|c|c|c|c|c|c|}
\hline${ }^{t}{ }_{D} / L T$ & $\mathrm{LT}_{\mathrm{A}}$ & $t$ & $Q_{t D} / Q_{p}$ & $Q_{p}$ & $Q_{t}$ \\
\hline $\begin{array}{l}\text { Time } \\
\text { ratio }\end{array}$ & $\begin{array}{l}\text { From } \\
\text { step } 5\end{array}$ & $\begin{array}{l}\text { Time } \\
\text { (hours) }\end{array}$ & $\begin{array}{c}\text { Discharge } \\
\text { ratio }\end{array}$ & $\begin{array}{c}\text { From } \\
\text { step } 2\end{array}$ & $\begin{array}{c}\text { Discharge } \\
\left(\mathrm{ft}^{3} / \mathrm{s}\right)\end{array}$ \\
\hline $\begin{array}{r}0.05 \\
.10 \\
.15 \\
.20 \\
.25\end{array}$ & $\begin{array}{r}0.62 \\
.62 \\
.62 \\
.62 \\
.62\end{array}$ & $\begin{array}{r}0.03 \\
.06 \\
.09 \\
.12 \\
.16\end{array}$ & $\begin{array}{r}0.07 \\
.10 \\
.15 \\
.21 \\
.28\end{array}$ & $\begin{array}{l}1,200 \\
1,200 \\
1,200 \\
1,200 \\
1,200\end{array}$ & $\begin{array}{r}84 \\
120 \\
180 \\
252 \\
336\end{array}$ \\
\hline $\begin{array}{l}.30 \\
.35 \\
.40 \\
.45 \\
.50\end{array}$ & $\begin{array}{l}.62 \\
.62 \\
.62 \\
.62 \\
.62\end{array}$ & $\begin{array}{l}.19 \\
.22 \\
.25 \\
.28 \\
.31\end{array}$ & $\begin{array}{l}.37 \\
.47 \\
.58 \\
.69 \\
.79\end{array}$ & $\begin{array}{l}1,200 \\
1,200 \\
1,200 \\
1,200 \\
1,200\end{array}$ & $\begin{array}{l}444 \\
564 \\
696 \\
828 \\
948\end{array}$ \\
\hline $\begin{array}{l}.55 \\
.60 \\
.65 \\
.70 \\
.75\end{array}$ & $\begin{array}{l}.62 \\
.62 \\
.62 \\
.62 \\
.62\end{array}$ & $\begin{array}{l}.34 \\
.37 \\
.40 \\
.43 \\
.47\end{array}$ & $\begin{array}{r}.87 \\
.93 \\
.97 \\
1.00 \\
.97\end{array}$ & $\begin{array}{l}1,200 \\
1,200 \\
1,200 \\
1,200 \\
1,200\end{array}$ & $\begin{array}{l}1,044 \\
1,116 \\
1,164 \\
1,200 \\
1,164\end{array}$ \\
\hline $\begin{array}{r}.80 \\
.85 \\
.90 \\
.95 \\
1.00\end{array}$ & $\begin{array}{l}.62 \\
.62 \\
.62 \\
.62 \\
.62\end{array}$ & $\begin{array}{l}.50 \\
.53 \\
.56 \\
.59 \\
.62\end{array}$ & $\begin{array}{l}.94 \\
.89 \\
.83 \\
.77 \\
.71\end{array}$ & $\begin{array}{l}1,200 \\
1,200 \\
1,200 \\
1,200 \\
1,200\end{array}$ & $\begin{array}{r}1,128 \\
1,068 \\
996 \\
924 \\
852\end{array}$ \\
\hline $\begin{array}{l}1.05 \\
1.10 \\
1.15 \\
1.20 \\
1.25\end{array}$ & $\begin{array}{l}.62 \\
.62 \\
.62 \\
.62 \\
.62\end{array}$ & $\begin{array}{l}.65 \\
.68 \\
.71 \\
.74 \\
.78\end{array}$ & $\begin{array}{l}.65 \\
.59 \\
.54 \\
.49 \\
.44\end{array}$ & $\begin{array}{l}1,200 \\
1,200 \\
1,200 \\
1,200 \\
1,200\end{array}$ & $\begin{array}{l}780 \\
708 \\
648 \\
588 \\
528\end{array}$ \\
\hline
\end{tabular}


Table 12.-- Example computation of simulated hydrograph for 100-year peak discharge for Sunnyside Canal at Orangeburg

(sta. no. 02173495)--Continued

[ $t_{D}$, time, in hours; $t$, time in hours; LT, lag time, in hours; LT, lag time adjusted for correct runoff volume, in hours; $Q_{t D}$, discharge at $t A^{A}$ e $t$, in cubic feet per second; $Q_{t}$, discharge at time $t$, ${ }_{3}$, cubic feet per second; $Q_{p}$, peak discharge, in cubic feet per second; $\mathrm{ft}^{3} / \mathrm{s}$, cubic feet per second]

\begin{tabular}{|c|c|c|c|c|c|}
\hline$t_{D} / L T$ & $\mathrm{LT}_{\mathrm{A}}$ & $t$ & $Q_{t D} / Q_{p}$ & $\mathbf{x}$ & $Q_{t}$ \\
\hline $\begin{array}{l}\text { Time } \\
\text { ratio }\end{array}$ & $\begin{array}{l}\text { From } \\
\text { step } 5\end{array}$ & $\begin{array}{l}\text { Time } \\
\text { (hours) }\end{array}$ & $\begin{array}{c}\text { Discharge } \\
\text { ratio }\end{array}$ & $\begin{array}{l}\text { From } \\
\text { step } 2\end{array}$ & $\begin{array}{c}\text { Discharge } \\
\left(\mathrm{ft}^{3} / \mathrm{s}\right)\end{array}$ \\
\hline $\begin{array}{l}1.30 \\
1.35 \\
1.40 \\
1.45 \\
1.50\end{array}$ & $\begin{array}{r}0.62 \\
.62 \\
.62 \\
.62 \\
.62\end{array}$ & $\begin{array}{r}0.81 \\
.84 \\
.87 \\
.90 \\
.93\end{array}$ & $\begin{array}{r}0.40 \\
.37 \\
.34 \\
.31 \\
.28\end{array}$ & $\begin{array}{l}1,200 \\
1,200 \\
1,200 \\
1,200 \\
1,200\end{array}$ & $\begin{array}{l}480 \\
444 \\
408 \\
372 \\
336\end{array}$ \\
\hline $\begin{array}{l}1.55 \\
1.60 \\
1.65 \\
1.70 \\
1.75\end{array}$ & $\begin{array}{l}.62 \\
.62 \\
.62 \\
.62 \\
.62\end{array}$ & $\begin{array}{r}.96 \\
.99 \\
1.02 \\
1.05 \\
1.09\end{array}$ & $\begin{array}{l}.26 \\
.24 \\
.22 \\
.20 \\
.19\end{array}$ & $\begin{array}{l}1,200 \\
1,200 \\
1,200 \\
1,200 \\
1,200\end{array}$ & $\begin{array}{l}312 \\
288 \\
264 \\
240 \\
228\end{array}$ \\
\hline $\begin{array}{l}1.80 \\
1.85 \\
1.90 \\
1.95 \\
2.00\end{array}$ & $\begin{array}{l}.62 \\
.62 \\
.62 \\
.62 \\
.62\end{array}$ & $\begin{array}{l}1.12 \\
1.15 \\
1.18 \\
1.21 \\
1.24\end{array}$ & $\begin{array}{l}.17 \\
.16 \\
.15 \\
.14 \\
.13\end{array}$ & $\begin{array}{l}1,200 \\
1,200 \\
1,200 \\
1,200 \\
1,200\end{array}$ & $\begin{array}{l}204 \\
192 \\
180 \\
168 \\
156\end{array}$ \\
\hline $\begin{array}{l}2.05 \\
2.10 \\
2.15 \\
2.20 \\
2.25\end{array}$ & $\begin{array}{l}.62 \\
.62 \\
.62 \\
.62 \\
.62\end{array}$ & $\begin{array}{l}1.27 \\
1.30 \\
1.33 \\
1.36 \\
1.40\end{array}$ & $\begin{array}{l}.12 \\
.11 \\
.11 \\
.10 \\
.09\end{array}$ & $\begin{array}{l}1,200 \\
1,200 \\
1,200 \\
1,200 \\
1,200\end{array}$ & $\begin{array}{l}144 \\
132 \\
132 \\
120 \\
108\end{array}$ \\
\hline $\begin{array}{l}2.30 \\
2.35 \\
2.40 \\
2.45 \\
2.50\end{array}$ & $\begin{array}{l}.62 \\
.62 \\
.62 \\
.62 \\
.62\end{array}$ & $\begin{array}{l}1.43 \\
1.46 \\
1.49 \\
1.52 \\
1.55\end{array}$ & $\begin{array}{l}.09 \\
.08 \\
.07 \\
.07 \\
.06\end{array}$ & $\begin{array}{l}1,200 \\
1,200 \\
1,200 \\
1,200 \\
1,200\end{array}$ & $\begin{array}{r}108 \\
96 \\
84 \\
84 \\
72\end{array}$ \\
\hline
\end{tabular}




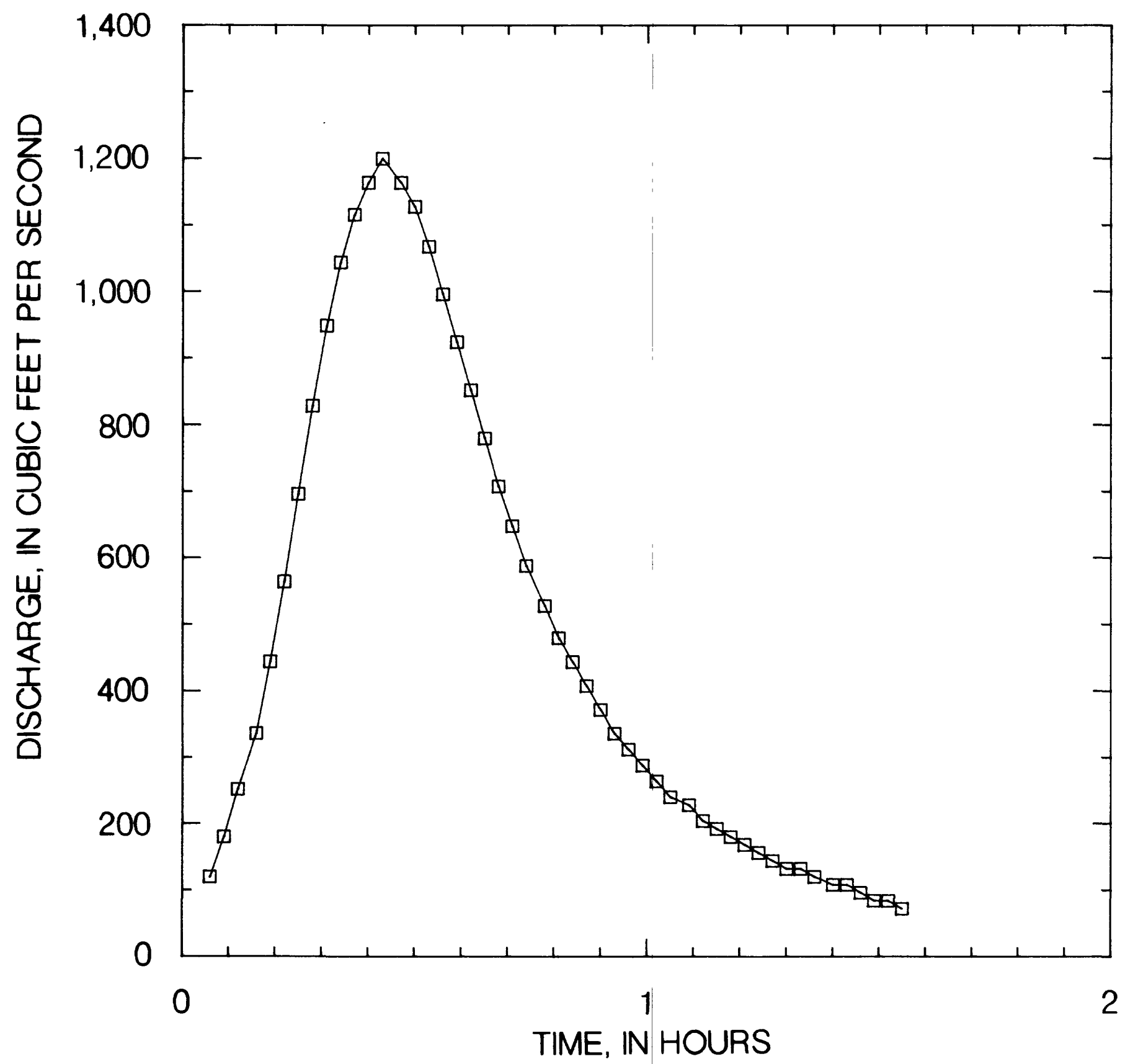

Figure 19.--Estimated hydrograph for the 100-year-peak discharge for Sunnyside Canal at Orangeburg. 


\section{SUMMARY}

Methods for determining peak-discharge-frequency relations, flood hydrographs, average basin lag times, and runoff volumes associated with a given peak discharge for ungaged urban basins were developed using data from 30 to 34 gaging stations in 15 cities in South Carolina, Georgia, and North Carolina. Example calculations for each method are presented as well as limitations for using them.

Concurrent rainfall and discharge data collected at 5- to 15-minute intervals from 1984 to 1990 from 23 small basins (less than 10 square miles) located throughout South Carolina and at varying levels of urban development were used to calibrate the U.S. Geological Survey rainfall-runoff model RRM. The calibrated model was used in conjunction with long-term ( 49 to 89 years) rainfall and evaporation records to synthesize hydrographs for the largest rainfall events for each year of record at each site. The logarithms of the largest annual peak discharge for each year were fitted to a Pearson Type III frequency distribution to develop a peak-discharge-frequency relation for each site. Multiple regression analysis was then used to relate various physical and climatic characteristics to the peak-discharge-frequency relations for the 23 South Carolina sites and 11 sites from previous studies in neighboring areas of Georgia and North Carolina. The significant explanatory variables in the estimating equations for peak discharges having recurrence intervals of $2,5,10,25,50,100$, and 500 years were drainage area, total impervious area, and equivalent rural discharge. Average standard errors of prediction for the peak-frequency equations range from \pm 25.6 to \pm 34.3 percent.

A regression equation for basin lag time, which is a required element for estimating flood hydrographs using the dimensionless hydrograph, was determined using data from 30 basins in South Carolina and Georgia. The significant explanatory variables for lag time were the ratio of channel length to the square root of channel slope, total impervious area, and the 2-year 2-hour rainfall amount. The lag time equation had an average standard error of prediction of \pm 23.8 percent.

Runoff volumes from 139 simple (non-compound) hydrograph events were related to various basin and hydrologic parameters using multiple regression analysis to provide two equations (one for the Piedmont-upper Coastal Plain and one for the lower Coastal Plain) for estimating the average volumes associated with a given peak discharge. Peak discharge, average basin lag time, and drainage area were determined to be the most significant explanatory variables in predicting runoff volume. The average standard error of prediction for the relations was \pm 18.7 percent.

Flood hydrographs were estimated by applying a specific peak discharge and an estimated basin lag time (adjusted for correct volume) to one of two dimensionless hydrographs derived in this study. The same rainfall and discharge data used to develop the runoff equations were used to compute average dimensionless hydrograph shapes for selected durations of rainfall excess and from various combinations of physiographic regions in South Carolina. Two dimensionless hydrographs were selected based on the best fit of observed hydrograph widths at 50 and 75 percent of observed stormflow. The one-fourth-1ag time duration Piedmont-upper Coastal Plain dimensionless hydrograph had standard errors of estimate of \pm 27.0 and \pm 29.8 percent for 
hydrograph widths at 50 and 75 percent of peak flow, respectively. The onethird-lag time duration dimensionless hydrograph developed from lower

Coastal Plain stations had standard errors of estimate of \pm 19.8 and \pm 24.5 percent, respectively, for widths at 50 and 75 percent of peak discharge.

A correction factor, F, must be applied to lag time prior to its use in estimating flood hydrographs using the dimensionless hydrograph. The ratio of regression volume to the volume under the appropriate dimensionless hydrograph is computed and multiplied by the average basin lag time in order to obtain correct volume for the estimated hydrograph. 


\section{SELECTED REFERENCES}

Alley, W.M., and Smith, P.E., 1982, User's guide for distributed routing rainfall-runoff model version II: U.S. Geological Survey Open-File Report 82-344, NSTL Station, Mississippi, 201 p.

Bodhaine, G.L., 1968, Measurement of peak discharge at culverts by indirect methods: U.S. Geological Survey Techniques of Water-Resources Investigations, book 3 , chapter A3, $60 \mathrm{p}$.

Bohman, L.R., 1990, Determination of flood hydrographs for streams in South Carolina; Volume 1. Simulation of flood hydrographs for rural watersheds in South Carolina: U.S. Geological Survey Water-Resources Investigations Report 89-4087, 53 p.

Boning, C.W., 1974, User's guide for a U.S. Geological Survey rainfa11runoff mode1: U.S. Geological Survey Open-File Report 74-33, 252 p.

Carrigan, P.H., Jr., 1973, Calibration of U.S. Geological Survey rainfall/runoff model for peak flow synthesis--natural basins: U.S. Geological Survey Computer Contribution, 109 p., available only from U.S. Department of Commerce, National Technical Information Service, PB$226-217$.

Carrigan, P.H., Jr., Dempster, G.R., Jr., and Bower, D.E., 1977, User's guide for U.S. Geological Survey rainfall-runoff models--Revision of Open-File Report 74-33: U.S. Geological Survey Open-File Report 77-884, $260 \mathrm{p}$.

Chow, V.T., 1964, Handbook of applied hydrology: New York, John Wiley, p. $12-1$ to $12-30$.

Corry, M.L., Jones, J.S., and Thompson, P.L., 1980, The design of encroachments on flood plains using risk analysis: U.S. Department of Transportation, Federal Highway Administration, Hydraulic Engineering Circular No. 17,84 p.

Cochran, W.G., 1963, Sampling techniques: New York, John Wiley, p. 71-86.

Dawdy, D.R., Lichty, R.W., and Bergmann, J.M., 1972, A rainfall-runoff simulation model for estimation of flood peaks for small drainage basins: U.S. Geological Survey Professional Paper 506-B, 28 p.

Guimaraes, W.B., and Bohman, L.R., 1992, Techniques for estimating magnitude and frequency of floods in South Carolina, 1988: U.S. Geological Survey Water-Resources Investigation Report 91-4157, $174 \mathrm{p}$.

Hess, G.W., and Price, McGlone, 1989, Comparison of methods for estimating flood magnitudes on small streams in Georgia, in Water Resources Bulletin, February, 1989, volume 25, number 1, p. 149-154. 
Hutchinson, N.E., compiler, 1975, WATSTORE, National water data storage and retrieval system--User's guide, v. 1: U.S. Geological Survey Open-File Report 75-426, 505 p.

Inman, E.J., 1983, Flood-frequency relations for urban streams in metropolitan Atlanta, Georgia: U.S. Geological Survey Water-Resources Investigations Report 83-4203, 38 p.

-..- 1986, Simulation of flood hydrographs for Georgia streams: U.S. Geological Survey Water-Resources Investigations Report 86-4004, 48 p.

-... 1988, Flood-frequency relations for urban streams in Georgia: U.S. Geological Survey Water-Resources Investigations Report 88-4085, 36 p.

Kirby, W.H., 1975, Model smoothing effect dininishes simulated flood peak variances: American Geophysical Union Transactions, v. 56, no. 6, $361 \mathrm{p}$.

Kohler, M.A., Nordensen, T.J., and Baker, D.R., 1959, Evaporation maps for the United States: U.S. Weather Bureau Technical Paper 37, 13 p.

Kraijenhoff van de Leur, D.A., 1966, Runoff models with linear elements, in Committee for Hydrological Research T.N.0., Recent trends in hydrograph synthesis: Verslagen En Mededelingen, Commissie Voor Hydrologisch Onderzoek T.N.O. 13, The Hague, p. 31-62

Lichty, R.W., and Liscum, Fred, 1978, A rainfall-runoff modeling procedure for improving estimates of $T$-year annual floods for small drainage basins: U.S. Geological Survey Water-Resources Investigations 78-7, $44 \mathrm{p}$.

Mitchel1, W.D., 1972, Model hydrographs: U.S. Geological Survey WaterSupply Paper 2005, 85 p.

Myers, R.H., 1986, Classical and modern regression with applications: Boston, Duxbury Press, 359 p.

Neely, B.L., Jr., 1989, Estimating flood hydrographs for Arkansas streams: U.S. Geological Survey Water-Resources Investigations Report 89-4109, 19 p.

O'Donne11, Terrance, 1960, Instantaneous unit hydrograph derivation by harmonic analysis: Commission of Surface Waters, Publication 51, International Association of Scientific Hydrology, p. 546-557.

O1in, D.A., and Atkins, J.B., 1988, Estimating flood hydrographs and volumes for Alabama streams: U.S. Geological Survey Water-Resources Investigations Report 88-4041, 25 p.

Philip, J.R., 1954, An infiltration equation with physical significance: in Proceedings, Soil Science Society of America, v. 77, p. 153-157. 
Putnam, A.L., 1972, Effect of urban development on floods in the Piedmont Province of North Carolina: U.S. Geological Survey, unnumbered OpenFile Report, 87 p.

Riggs, H.C., 1968, Some statistical tools in hydrology: U.S. Geological Survey Techniques of Water-Resources Investigations, book 4, chapter A1, $39 \mathrm{p}$.

Robbins, C.H., 1986, Techniques for simulating flood hydrographs and estimating flood volumes for ungaged basins in central Tennessee: U.S. Geological Survey Water-Resources Investigations Report 86-4192, 32 p.

Rogers, W.F., and Zia, H.A., 1982, Linear and nonlinear runoff from large drainage basins: Journal of Hydrology 55, p. 267-278.

Rosenbrock, H.H., 1960, An automatic method of finding the greatest or least value of a function: Computer Journal, v. 3, p. 175-184.

SAS Institute, Inc., 1985, SAS User's guide: Statistics, 583 p.

Sauer, V.B., 1964, Magnitude and frequency of storm runoff in southeastern Louisiana and southwestern Mississippi: U.S. Geological Survey

Professional Paper 501-D, p. D182-D184.

Sauer, V.B., Thomas, W.0., Stricker, V.A., and Wilson, K.V., 1983, Flood characteristics of urban watersheds in the United States: U.S. Geological Survey Water-Supply Paper 2207, 63 p.

Sherwood, J.M., 1986, Estimating peak discharges, flood volumes, and hydrograph shapes of small ungaged urban streams in Ohio: U.S. Geological Survey Water-Resources Investigations Report 86-4197, 52 p.

Singh, V.P., and Aminian, Hossein, 1986, An empirical relation between volume and peak of direct runoff, in Water Resources Bulletin, October, 1986, volume 22, number 5, p. 725-730.

Stricker, V.A., and Sauer, V.B., 1982, Techniques for estimating flood hydrographs for ungaged urban watersheds: U.S. Geological Survey OpenFile Report 82-365, 24 p.

U.S. Water Resources Council, 1981, Guidelines for determining flood-flow frequency: U.S. Water Resources Council Bulletin 17B, 28 p.

Weather Bureau, 1961, Rainfa11-frequency atlas of the United States: Weather Bureau Technical Paper 40, 115 p.

Whetstone, B.H., 1982, Techniques for estimating magnitude and frequency of floods in South Carolina: U.S. Geological Survey Water-Resources Investigations Report 82-1, 78 p. 


\section{GLOSSARY}

Terms and symbols related to streamflow, basin characteristics, and other hydrologic data, as used in this report are defined below and shown in bold type in text. They are not necessarily the only valid definitions for these terms.

A Drainage area -- The contributing drainage area, in square miles, measured in a horizontal plane from U.S. Geological Survey 7.5-minute topographic quadrangle maps. In urban areas, drainage systems sometimes cross topographic divides. Such drainage changes should be accounted for when computing A.

BDF Basin development factor - - An index of the prevalence of the drainage aspects of (a)storm sewer, (b)channel improvements, (c)impervious channe1 linings, and (d)curb-and-gutter streets. The range of BDF is from 0 to 12. A value of zero for BDF indicates the above drainage aspects are not prevalent, but does not necessarily mean the basin is nonurban. A value of 12 indicates full development of the drainage aspects throughout the basin. Sauer and others (1983) describe how to compute BDF.

F Volume correction factor -- Factor used to adjust average basin lag time prior to applying the dimensionless hydrograph technique. It is computed as the ratio of regression volume to dimensionless volume.

K Volume conversion constant - - A conversion constant required to compute volume, in watershed inches, associated with the dimensionless hydrographs developed in this report.

L Main channel length -. The length, in miles, along the main channe1 from the gaging station (or point of interest) to the basin divide.

LT Average lag time - - Time difference, in hours, between the centroid of the rainfall excess and the centroid of the direct runoff hydrograph.

LT Adjusted lag time - - Average basin lag time, in hours, adjusted to obtain the correct runoff volume using volume correction factor, $F$.

Q Peak discharge - - The maximum discharge, in cubic feet per second, associated with an observed or estimated flood hydrograph.

$Q_{t}$ Discharge - - The discharge of an estimated flood hydrograph at time $t$.

$Q_{\text {tD }}$ Dimensionless hydrograph discharge - - Discharge coordinate, in cubic feet per second, of the numerator in the dimensionless hydrograph discharge ratio.

RI2 2-year 2-hour rainfa11 - - Rainfall amount, in inches, for the 2-year 2-hour occurrence, determined from Weather Bureau (1961). 
$\mathbf{R Q}_{\mathbf{T}}$ Rural peak discharge - - The peak discharge, in cubic feet per second, for an equivalent rural drainage basin in the same hydrologic area as the urban basin, and for recurrence interval $T$. For this study, equivalent rural discharges were computed using regional equations from Guimaraes and Bohman (1992). The rural equations are provided in this report.

S Main channel slope -- The main channel slope, in feet per mile, measured between points that are 10 percent and 85 percent of the main channel length upstream from a stream-gaging station (or other point of interest) as determined from U.S. Geological Survey 7.5minute topographic quadrangle maps.

$t$ Time - Time, in hours.

T Recurrence interval - - The average interval of time, in years, within which a given hydrologic event will be equaled or exceeded once.

t Dimensionless hydrograph time - - Time coordinate, in hours, of the numerator in the dimensionless hydrograph time ratio.

TIA Total impervious area -- The percentage of the drainage basin occupied by impervious surfaces, such as houses, other types of buildings, streets, parking lots, and so forth.

UQ Urban peak discharge - - The peak discharge, in cubic feet per second, for the urban watershed for recurrence interval $T$.

$V_{D}$ Volume of simulated hydrograph - - The average total runoff volume, in inches, computed by numerically integrating the total area under a hydrograph estimated using the dimensionless hydrograph methods presented in this report.

$\mathbf{V}_{\mathbf{R}}$ Volume of hydrograph - - The total runoff volume, in inches, for a typical hydrograph, as determined from regression equations presented in this report.

w Hydrograph width - - Period of time, in hours, for which a particular discharge will be exceeded. 
SUPPLEMENT A.--Rural flood-frequency equations for ungaged sites in South Carolina (from Guimaraes and Bohman, 1992)

Flood discharge,

$Q_{T}$, in cubic

feet per second, for recurrence interval $\mathbf{T}$ (years)

Regression equations for the indicated physiographic provinces

Lower Coastal Upper Coastal Piedmont Blue Ridge Plain Plain

\begin{tabular}{lllll}
\hline$Q_{2}=$ & $56 A^{0.63}$ & $25 A^{0.74}$ & $127 A^{0.66}$ & $103 A^{0.79}$ \\
$Q_{5}=$ & $111 A^{0.61}$ & $44 A^{0.72}$ & $211 A^{0.64}$ & $196 A^{0.76}$ \\
$Q_{10}=$ & $157 A^{0.59}$ & $59 A^{0.71}$ & $267 A^{0.64}$ & $286 A^{0.73}$ \\
$Q_{25}=$ & $221 A^{0.59}$ & $80 A^{0.70}$ & $347 A^{0.63}$ & $429 A^{0.70}$ \\
$Q_{50}=$ & $275 A^{0.58}$ & $97 A^{0.70}$ & $410 A^{0.63}$ & $558 A^{0.69}$ \\
$Q_{100}=$ & $335 A^{0.58}$ & $116 A^{0.69}$ & $474 A^{0.63}$ & $705 A^{0.67}$ \\
$Q_{500}=$ & $569 A^{0.52}$ & $179 A^{0.66}$ & $615 A^{0.63}$ & $1146 A^{0.63}$ \\
\hline
\end{tabular}




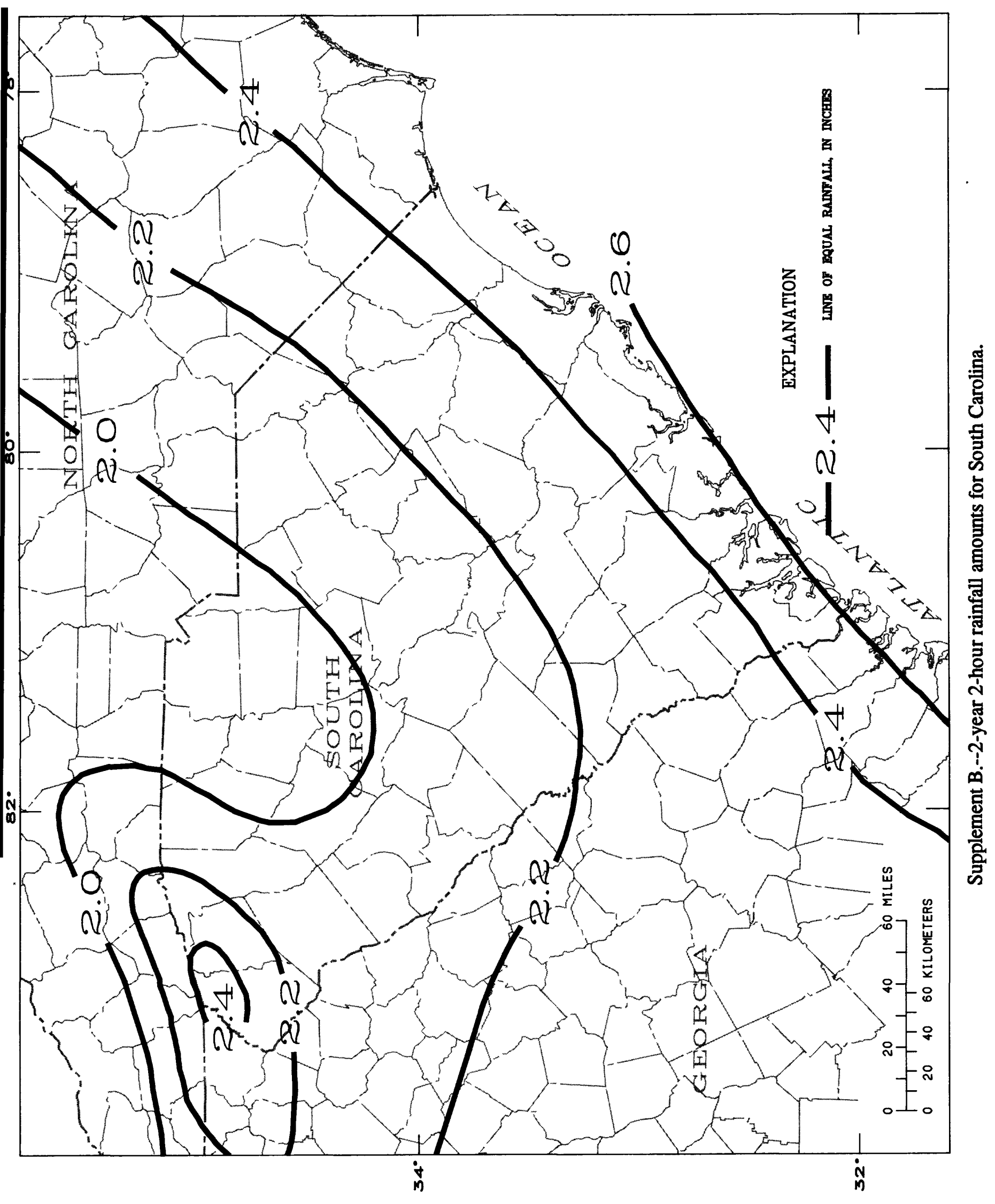

